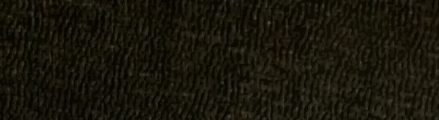

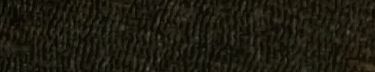
3. 


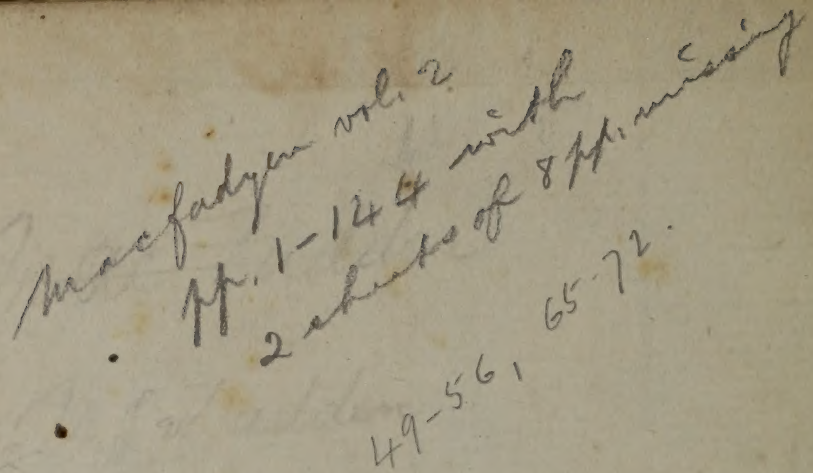

\section{+Qk231:m32 v2}

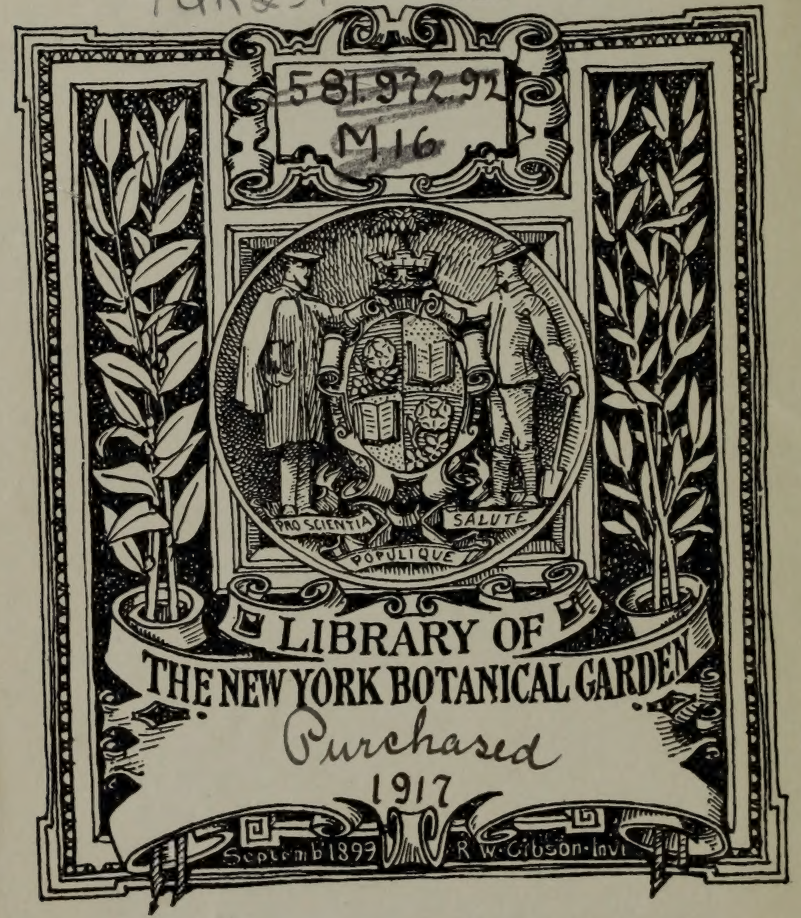


Sonants

If. hat ale

Indies bis Guidon

189 
- M32

$$
\therefore, 2
$$




\section{L:HZARY \\ NL, IORK \\ BOT ANICAL \\ G.ARDEN}

THE

\section{FLORA OF JAMAICA.}

\section{A L Y C I F L O R E,}

\section{(Continued.)}

\section{ORDER LV. ROSACEE.}

Calyx 4-5-lobed, generally persistent. Petals 5, equal, inserted on the calyx. Stamens generally indefinite, inserted with the petals; filaments incurved during æstivation; anthers 2 -celled, bursting longitudinally. Ovaries superior, either solitary or several, 1-celled: styles lateral, dilated at the apex to form the stigmata. Fruit either 1seeded nuts, or acini, or follicles containing several seeds; seeds usually 1-2 in each carpel, erect or inverted, exalbuminose ; embryo straight.

Herbaceous, shrubby, or arborescent: leaves alternate, bi-stipulated at the base, simple or compound. 


\section{Tribe I. Chrysobalanea.}

\section{Chrysobalanus.}

Calyx bell-shaped, 5-fid. Petals 5, clawed. Stamens about 20, uniserial, subequal. Drupe plum-shaped; putamen ovate, 6 -sulcated, 6 -valved, 1-seeded; kernel fleshy, thick-D $\boldsymbol{C}$.

Low trees; flowers racemed or panicled.

Name from $\chi_{\text {puros }}$ Gold, and badavos an acorn; in allusion to the size, colour, and form of the fruit.

\section{Chrysobalanus Icaco. Cocoa Plum.}

Leaves subrotundo-obovate subemarginate, racemes axillary dichotomous, stamens hairy.

Frutex fructu ovali cœruleo, Catesb. Car. 1. 25. t. 25.-Icaco fructu ex albo rufescente; et Icaco fructu purpureo, Plum Gen, 44.-Chrysobalanus, Browne, Jam. 250. t. 17. f. 5.-Jacq. Am. 154. t. 94.-Kunth, Syn. Pl. AEq. III. 483.-C. pellocarpus, Meyer. Primit. Essequeb. 193.

H A B. Morass near Bybrook Estate, St. Thnmas in the Vale. Cultivated.

î L. March-May. After rains.

A shrubby tree, about 12 feet in height: branches spreading, of a ferruginous colour, with white papillæ. Leaves alternate, nerved, coriaceous, shining above, very glabrous : petiole short, incrassated. Racemes axillary, dichotomously branched, solitary, shorter than the leaf: common peduncle plane on the inner surface, rounded on the outer, puberulous ; terminal divisions 3 -flowered. Flowers shortly pedicelled, white, crowded. Bracteoles ovato-lanceolate, deciduous, a pair below each flower. Caly x 5-partite; divisions ovate, acute, puberulous, ciliated, sub-persistent. Petals 5, white, obovato-oblong, ot tuse, scarcely longer than the calyx, deciduous. Stamens numerous; filaments compressed, hairy, length of the petals, persistent. Ovary subrotund, villous; style arising from one side of the base of the ovary, length of the stamens, villous; stigma obtuse. Fruit ovali-subrotund, size of a large plum, of a white, yellow, red, or purple colour, glabrous with exception of a few minute scatter- 
ed hairs: pulp adhering firmly to the shell, white, of a sweetish slightly austere but rather agreeable taste: shell with the base lateral ( $i$. e. not in the axis of the pedicel), 6-sulcated at the base, and 6-valved, with each of the valves marked with a faint longitudinal ridge, reticulated.

The c. PELlocarpus of Meyer cannot be considered as distinct from the present species, the characters derived from the form of the leaves and fruit being uncertain and apt to vary.

The Cocoa-plum grown in this Island is always of a brownish-purple colour. It is considered astringent, and to be useful in bowel complaints. Prepared with sugar, it forms a favourite conserve with the Spanish Colonists, and large quantities are annually exported from Cuba. The kernels yield a fixed oil, and an emulsion, made with them, is said to be useful in dysentery An astringent bath, recommended in leucorrhœa and blennorrhœa, is prepared from the leaves and roots.

\section{Hirtella.}

Calyx obtusely 5-lobed, generally at length reflected. Petals 5, small, deciduous. Stamens $\mathbf{- 1 5}$ [very probably 5-15]; filaments long, twisted previous to æstivation in a circle. Style from the base of the ovary, opposite to the stamens. Drupe sulcated, 1-celled. :eed stipitate from the fundus, erect; albumen fleshy; embryo straight; cotyledons leafy.-Gartn. et $D$ Q

American shrubs: leaves entire, furinished with stipules; racemes axillary or terminal, simple or oethpound.-Name from hirtus, hairy; the plants belonging to the genus having more or less of this character.

\section{Hirtella triandra. South American Hirtella.}

Flowers 3-androus, petals ovate, racemes compound axillary and terminal, rachis pubescent, leaves oblong acuminate subglabrous.

Swartz, Fl. Ind. Occ. E 08.-H.Americana, Jacq. Amer. 8. t. 8 . 


\section{A B. Mountain woods. Port-Royal Mountains.}

\section{F L. August.}

A spreading tree of moderate height; branclilets sub. terete, verrucose, villous towards the extremities. Leaves alternate, petiolate, subdistichal, about 3 inches in length, ovato-oblong, acuminate, entire, thin, smooth and somewhat shining above, pubescent especially along the nerves beneath: petiole very short, villous. Racemes terminal, and in the axils of the subterminal leaves, compound, many-flowered, shorter than the leaves: flowers small, white, pedicelled, 3-4 together, furnished with minute subulate bracteæ at the insertion. Calyx 5-partite; divisions ovate, obtuse, externally puberulous, persistent. Petals usually on y 3 (the place of two others being vacant), white, ovate, obtuse, deciduous. Stamens 3, long, capillary, spirally twisted and purple towards the extremity, broader at the base, compressed, puberulous, connected so as to form an urceolate nectary, with a vacant space for the two filaments which are deficient; anthers roundish, purple. Ovary compresso-declinate, villous; style arising from the side of the ovary, length of the stamens, hairy towards the base; stigma obtuse, green. Drupe, dry, oblong, truncated at the apex, large, compressed, 3-ribbed on each side, velutino-villous, green, 1-celled, 1-seeded.

The above description agrees pretty closely with that of Swartz, except that the leaves are stated by him to be smooth and shining. and the petiole glabrous. $\mathrm{He}$ also describes the raceme as a half a foot in length, from considering, in my opinion incorrectly, the terminal and axillary racemes on each branch as constituting a single compound raceme.-The flowers are small and unattractive, and the wood is fragile.

\section{Tribe II. Amygdalea.}

\section{IIi. Cerases. Cherry.}

Drupe globose or umbilicated at the base, fleshy, very smootb, destitute of a cheesy pollen: nut sub-globose, smooth.- $D C$.

Leaves when young conduplicated. Flowers either on 1-flowered pedicels, many together, umbellato-fasciculated, arising from a scaly bud, and more forward than the leaves; or branched, terminal, and evolved after the 
leaves.-Name from Cerasus a town of Pontus in Asia, whence Lucullus is said to have introduced into Italy the cultivation of the Cherry, 73 years B. C.

\section{Cerasus Occidentalis. Prune Tree.}

Racemes lateral, stamens 25-26, leaves oblong acuminate very entire glabrous on both sides.

Amygdalus foliis magnis, Nicolson's Doming, 154Cerasus latiore folio, fructu racemoso purpureo majore, Catesb. Carol. II. 94, . 94 ?-Prunus Occidentalis, Swartz, Fl. Ind. Occ. 925.

H A B. Common in the woods of the interior.

F L. February.

A lofty tree; branchlets terete. Leaves $5-6$ inches in length, and $2-2 \frac{1}{2}$ in breadth: petioles angulated. Racemes lateral, elongated, many-flowered. Flowers rather large, yellowish-white, pedicelled. Calyx turbinate; teeth erect, acute. Petals inserted between the t eth of the calyx, ovate, patent, subreflex, deciduous. Filaments 25-36, subulate, erect, inserted on an orangecoloured cup-shaped nectary, firmly adherent to the calyx : anthers oblong. Ovary globose, green, puberulous: style subulate, shorter than the stamens: stigma capitato-depressed. Drupe oblong, size of the common Plum of Europe, purple : nut smooth.

The bark of this tree has an astringent taste, with a strong flavour of Prussic acid, and is used in manufacturing an inferior description of Noyau, known by the name of Prune-dram. It is from the kernels of the drupe that the celebrated liqueur, the Noyau of Martinique, is prepared. They yield a flavour much superior to that of the peach, being rich, oily, and nutty, combined with that of Prussic acid. The timber of the tree itself, is of a red colour, resembling. cedar, and is very hard and durable, and, from its taking a fine polish, makes a beautiful flooring for houses. But it is not adapted for out door work, or where it is exposed to the weather ; for in such situations it very soon rots.

\section{Cerasus sphærocarpa, Round-Fruited Prune Tree.}

Racomes axillary erect shorter than the leat, 
stamens 12-20, leaves very entire shining ovatolanceolate, fruit subglobose.

A mygdalus foliis parvis, Nicolson's Doming. 154--Myrtifolia arbor, foliis latis subrotundis, flore albo, Sloane, Hist. II. 79 t. 193. f. 1.--Prunus sphærocarpa, Swartz, $\boldsymbol{F l}$. Ind. Occ. 927.--Cerasus sphærocarpa, Loisel. in Duham. ed. nov. V. 4,-Bot. Mag. 3141.

II A B. Common, in the lower mountains.

F L. February.

A tree, 15-20 feet in height. Leaves alternate, petiolate, ovato-lanceolate with the apex blunt, indistinctly nerved, very glabrous, shining: peliole terete. Racemes axillary, solitary or rarely 2 together, much shorter than the leaves. Flowers sinall, numerous, shortly pedicelled, white, slightly fragrant: pedicels each furnished with a minute bractea at the insertion. Calyx turbinate, 5-rarely 4-toothed; teeth minute, patent. Petals 5, rarely 4, rounded, waved, slightly clawed, alternating with the teeth of the Calyx. Stamens 12-20, rather longer than the petals; filaments subulate, submonadelphous at the base, inserted into the cup-shaped yellow nectary, adherent to and covering the inner surface of the tube of the calyx. Ovary ovate: style length of the stamens : stigma capitato-depressed. Fruit spherical, size of a small cherry, purple, ripening in August : kernel of a warm acrid taste, with a strong flavour of Prussic acid.

The flowers of some trees of this species are imperfect, and in such the fruit is never perfected.

\section{Rubus. Bramble.}

Calyx 5-cleft, naked. Petals 5. Stamens $\infty$ Fruit superior of several single-seeded juicy drupes with sublateral styles, placed on a protuberant spongy receptacle.

Shrubs, or more rarely herbaceous plants: stems bien. nial, in general prickly; usually growing in hedges, or in waste places. The truit of all the species is edible.Alame derived from the Latin RUBER.

\section{Rubus Jamaicensis. Jamaica Bramble or Black-berry.}

Stem anguloso-sulcated villous, prickles scat- 
tered recurved, leaves 5-3-nato-palmate sericeovillous, leaflets elliptico-ovate attenuato-acuminate finely serrated, flowers panicled, sepals externally niveo-scriceo-tomentuse.

Rubus foliis longioribus subtus molli lanugine obductis et incanis, flore et fructu minoribus, Sloane II. 109. t. 213. f. 1.-R. aculeatus, Browne, 342.--R. Jamaicensis, Swartz. obs. 205.

H A B. Common in the mountains.

F L. Throughout the year, but principally during the Spring and Summer.

A shrub, with long trailing branches. Leaflets 5, more rarely 3 , unequal, petiolulated, penni-nerved with recurved hooked prickles along the under surface of the mid-rib, villous and silky above, hairy and tomentose beneath: common petiole elongated, 3-gonal, villous, with hooked recurved prickles beneath. Stipules setaceous. Panicle terminal; branches subsimple: flowers white, pedicelled; bracteæ at the divisions of the panicle and at the base of the pedicels, lanceolate, acute. Sepals lanceolate. Petals roundish, concave, slightly clawed. Stamens numerous. Styles many: stigmata subcapitate. Fruit globular, rather smaller than that of the common bramble (R. FRUTicosus) of Europe.

The fruit of this species is very palatable, and is employed for tarts and other sweetmeats. Infused in spirit, with the bruised kernels of the West India Prune-tree ( $\mathrm{CE}$ RASUs OCcIDENTALIS), and sweetened with sugar, a liqueur is obtained, not inferior to, and not to be distinguished from the Copenhagen Cherry Brandy which is imported into this Island from St. Thomas. The fruit of an allied species (R. OCCIDENTALIS), dried and powdered, is recommended for Dysentery, (Bulletin des Sciences Merlicales, XIX 129), and the root was considered by the Oneida Indians as a specific for the same complaint.

\section{Rubus Alpinus. Alpine Bramble.}

Stem anguloso-sulcated glabrous prickly, leaves 3-nato-palmate glabrous ovate attenuato-acuminate serrated, calycine divisions lanceolate sparingly woolly.

H A B. The higher mountains.

F L. Middle of the year. 
In its mode of growth, it resembles the preceding. Branches glabrous, angular, coloured, armed with recurved prickles. Leaves pinnato-ternate; leaflets ovate attenuated at the apex, sharply serrated, armed on the under surface of the mid-rib with curved prickles, glabrous. sitipules setaceous. Flowers panicled, numerous, white, with a purplish tinge; branches slightly woolly. Calycine segments lanceolate, slightly woolly. Fruit smaller than in the preceding species, but of a deeper purple.

This is very readily distinguished from the preceding species by the almost entire absence of wonlliness, and by the nurule tinge of the branches and panicles.

\section{ORDER LXVI. GRANATEE.}

Calycine tube turbinate; limb 5-7-fid; æstivation valvular. Petals 5- 7 Stamens $\infty$; anthers on the fore part of the filament, 2-celled, Style filiform; stigma capitate, papilose. Fruit crowned with the subtubulose limb of the calyx, and with the outer rind formed by the same; indehiscent, divided into two unequal chambers by a horizontal diaphragm; the upper chamber subdivided by membranaceous partitions into 5-9 cells; the lower one into 3 cel!s. Seeds innumerable, ber ried in a pellucid subcristalline pulp, exalbuminous ; embryo oblong; radicle short, straight ; cotyledons leafy, spirally convoluted.

Low trees or shrubs, with branches subtetragonal and subspinescent; and with leaves impunctate, and destitute of a marginal nerve. - This order was established by $\mathrm{Mr}$. Don, and has been adopted by De Candolle. It comprehends only two plants, the common and the Dwarf Pomegranate. They have been more recently replaced among the Myrtaceæ, and Dr. Lindley has given it as his opinion, that they do not require to be distinguished from the true members of that tribe, even as a section. Notwithstanding this, I prefer, for obvious reasons, retaining the arrangaof De Candolle. 


\section{Punica. Pomegranate.}

\section{The generic character is the same as that of the Order.}

The name, according to some Authors, is derived from PUNICEA scarlet, the colour of the flowers. Others again refer it to Punicus, and that it was so called from the circumstance that the tree was first cultivated extensively in the neighbourhood of the ancient Carthage, and that hence the fruit received the name of MaLUM PUNicum or Carthagenian apple.

\section{Punica Granatum. Common Pomegranate.}

\section{Leaves lanceolate, stem arborescent.}

De Cand. Prod. IlI. 3.

H A B. Cultivated.

F L, Throughtout the year.

The Pomegranate is originally a native of Syria. It appears to have been introduced into this island at a very early period after its sttlement by the spa. niards. It is a shrub a ${ }^{\text {hout }} 10$ feet in height. The flowers are very showy ; are either scarlet or more rarely white, and single or couble. The common or single red variety is very generally cultivated, especially in Kingston, and its vicinity, anu the fruit acquires great perfection, being of an agreeable $\mathrm{fl}$ ivour, and weighing sometimes, according to Lunan, a pound and a half. The double red, and the single and double white, have been introduced, but the heat of the climate does not appear to agree with them, and I have of late lost sight of them. The Pomegranate is principally cultivated tor the sake of the Fruit, which deserved y claims a place at the dessert. The seeds are surrounded by a transparent reddish pulp of a sweetish but astringent taste, peculiary grateful in a tropical climatc. Several parts of the plant have also been used in medicine. The root, and especially its bark, is a powerful remedy for Tupe-worm, and was recommended as such by Dioscorides, Pliny, and Celsus. It does not however appear to have again attracted notice as an article of the Materia Medica, until attention was called to it, by Dr. Buchanan, in the $3 \mathrm{~d}$ volume of the Edinburgh Medical and Surgical Journal, as a powerful vermifuge in com. 
mon use from time immemorial in India. As to the mode of administering, the directions given by Celsus are; "Cum pridie multum allium ederit, vomat posteroque die, mali punicis tenues radiculas colliegat quantum manu comprehendet; eas contusas in aquæ duobus sextariis decoquat, donec tertia pars supersit; huic adjiciat nitri panlum et jejunus bibat." It is directed, in the Dictionnaire de Matiere Medicale that two ounces of the fresh root be boiled in a pint and a half of water to one pint, a third of which is to be a dose, and repeated every hour till the whole is taken. It is recommended to be administered in the morning, on an empty stomach, and followed by a dose of oil. In the same work it is stated that this decoction has been employed as a remedy for the round worm and ascarides, and it has been found superior to any other medicine. It may be given for the round worm in doses of two drachms-to half an ounce; and for the ascarides it ought to be given in injection. When the root is dried, a smaller proportion of it is to be used in preparing the decoction. The effects of an over dose are, sickness at the stomach, giddiness, uneasiness in the bowels, and sometimes headache. Dr. Elliotson c msiders, the bark of the root in the state of powder the most effectual form. From one to two drachms may be given three times daily, followed, the ensuing morning, by a dose of oil.

The rind of the fruit has also a place in the Materia Medica. It is very astringent, containing gum extract, and tannin or tariric acid. A decoction prepared from it has obtained a place in the London Pharmacnpeia for 1836 . Two ounces of the rind are directed to be boiled in a pint and a half of dis. tilled water to one pint: the dose of the strained $\mathbf{L i}$ quor is from half an ounce to an ounce. It has been found useful not only in cases of Tapeworm, but also in dysentery, and leucorhhœa.

'The blossoms or flowers, called balaustium, Pliny informs us, were emllyyed in his time as medicinal, and in $d y$ ing cloth. The infusion is occasionally used as a vehicle in gargles and for astringent mixtures.

The Pomegranatc appears to have been very common in Palestine, ana must !rive attained as a tree a considerable height, as we read in 1. Samucl 14.2. "That saul tarried in the uttermust ort of Gitreah, under a pomegranute tree, which is in Migron." The fruit was at that time highly estecmed, and we accordingly find fiequent allu- 
sions to it in the similitudes employed in Scripture. The blue robe or ephod of the High Priest, was embroidered with pomegranates, and the chapiters of the pillars in the Holy of Holies were ornamented with representations of them.

\section{ORDER LXVII MEMECYLEA.}

Calycine tube ovate or subglobose, adhering to the ovary; limb short, 4-5-lobed or 4-5 toothed. Petals 4-5, inserted into the calyx, and alternate with its lobes. Stamens $8-10$ or double the number of the petals; filaments free: anthers-2-celled. Berry 2-4 celled : seeds tew, exalbuminose : cotyledons leafy, convoluted: radicle straight.

Intertropical shrubs, with simple leaves, and axillary flowers. This has been united by Dr. Lindley with the MELASTOMACEE.

\section{Mouriria.}

Calyx bi-squammose at the base, with the limb urceolate and 4-toothed. Petals 5, broad at the base, inserted on the calyx, alternate wilh its teeth, contorted during rstivation. Stamens 10, subunequal; anthers biporose at the apex. Orary subglobose: style filiform : stigma capitate. Berry crowned with the calyx, globose, 1-1-celled, 1-4seeded.

Name from mouriria the native name of M. GUIANEnsis.

\section{Mouriria myrtilloides. Silver-wood.}

Leaves subsessile ovate attenuated oblique at the base, pedicles solitary l-flowered. 
Myrti foliis arbor cortice argenteo? Sloane, Hist. II. 78 t. 187. f. 3.-Arbor foliis cordatis myrtineis oppositis, bacc's dispermis; Browne Jam. 370.-Petaloma myrtilloides, Swartz. Fl. Ind. Occ. II. 833.-Mouriria myrtilloides, $D C$. Prod. III. 7.

H A B. St John's hills.

F L. April. May.

There appears reasons for doubting whether the plant of Swartz, be identical with that of sloane and Browne. The latter describe their plant as being a tree, twenty feet in height. As I have not met with the plant, I give the description of Swartz.

A shrub, 2-3 feet in height, with the bark ferrugineous with silvery white spots: leaves subsessile, ovate, nerveless, entire. Peduncles axillary, soli'ary, longer than the petiole, 1-flowered. Flowers rather large, white. Calyx urceolate, 5-fid: divisions patent, reflected, persistent. Petals 5, shortly clawed, oblong, acuminate, patent, deciduous. Stamens 10: filaments subulate, erect: anthers rather large, biporose, yellow. Style rather thick, curved at the apex: stigma obtuse. Berry ovate, 1-seeded, black, shining.

\section{* order ldvili comeretace.}

Flowers hermaphrodite, rarely, from abortion, polygamous. Tube of the Calyx adhering to the ovary; limb 4-5-lobed. Petals none, or $\mathbf{4 - 5}$, alternating with the lobes of the calyx, inserted on the apex of the tube. Stamens with a similar insertion : anthers '2-celled, opening by 2 longirudinal clefts. Orary 1-celled; ovules $2-4$, pendulous from the apex: style 1; stigma simple. Fruit drupaceous, berried, containing a nut, Icelled, by abortion 1-seeded, indehiscent, generally furnished with wings: seed pendulous, filling the cavity of the pericarp, exalbuminose : embryo 
with the radicle directed towards the hilum; plumule inconspicuous; cotyledons leafy, usually convolute, occasionally plaited.

Trees or shrubs: leaves without stipules, entire: spikes axillary or terminal. Natives of Tropical countries. The bark of several of the species is astrirgent and used for tanning, and the timber is durable and much esteemed.

\section{Bucida.}

Calyx with the limb campanulato-urceolate, 5-toothed, deciduous. Petals $\bigcirc$. Stamens 10, arranged in two rows; 5 at the base of the limb, and five longer bctween the divisions; anthers didymous. Style subulate. Drupe berried: nut angulated; ovules 2 ; seed 1, cy lindraceo-oblong.

West-India trees. Leaves scattered, collected at the end of the branchlets : peduncles axillary : flowers spiked, or capitate. Name from $\beta_{s s}$ an $O_{x}$; the form of the ripe fruit bearing a resemblance to the horn of that animal.

\section{Bucida buceras. Olive-bark tree.}

Leaves cbovate wedge-shaped obtuse glabrous, flower-spikes cylindrical, rachis appresso-serîceo-pubesent.

Mangle julifera, foliis subrotundis versus summitatem latissimis confertim nascentibus, cortice ad coria densanda utili, Sloane, Jam. Hist. II. 67. t. 189. f. 3.-Buceras, Browne, Jum. 221. 1. 23. f. 1.-Bucida buceras, Swartz, Obs. 180.

H A B. Sea shore, in marshy situations. Near the Ferry Inn. Port-Morant.

F L. Spring.

A Tree, 20-30 feet in height: branches horizontally spreading, divaricating, terete, smooth, striated. Leaves crowded at the bifurcation and at the extremities of the branches, petiolate, obovate, entire, coriaceous, obscurely nerved, glabrous, but when young sericeo-pubescent on the 
under surface. Spilies axllary, longer than the leares, many flowered: peduncle terete, appresso-sericeo-pub. escent on the under surface. Flowers yellowish. Calyx campanulate: limb 5-toothed, deciduous. Petals $\odot$. Stamens 10, twice the leligth of the Calyx. Orary de. pressed, 10-striated at the base: style subulate, hairy at the base. Berry dry, 1-celled, crowned with the truncated remains of the limb of the calyx : seed single, ovate,

The specific designation, Puceras. bull's horn, is applied, from a long spongy horn-shaped excresence, probably from the perforation of some insect, being produced from the extremitits of the branches. I must however acknowledge, that although I have looked for this in many individuals of the species, I have never yet met with it. This is an excellent timber tree, and the wood is frequently employed by cabinet-makers in manufacturing ornamental and farcy articles of furniture. The bark is em. ployed in tanning; but the tree is by no means common, and on that account is unable to supply the demand. sloune intorms us that in his time the bark was used "in tannirg of sole leather."

\section{Bucida capitata, Yellow Sanders.}

Leaves obovate wedge-shaped at the base emarginate or rounded at the apex, villoso-ciliated when young, flowers crowded in sub-ylobose spikes.

Cucurbitifera arbor forte, foliis subrotundis confertim nascentibus, ramulorum extremitatibus tumidis, Sloane II. 176. t. 228. f. 3.-Hudsonia arborea, Hort. Jam, II. 310. -Bucida capitata, Vahl. Ecl. I. 50 t. 8.

IIAB. Port Royal Mountains, where the white limestone prevails.

F L. A pril.

A tree usually lofty, 30-60 feet in height, of a handsome port ; branches horizontal ; branchlets ferrugineotomentose, tuberculated with the scars of the old leares which have dropt off. Leaves 12 or more together, crowded, at the ends of the branchlets, petiolated, an irch and a half long, and scarcely one broad, round and occasionally emarginate at the apex, leathery, shining, glab. rous and green above, pubescent beneath; the young leaves villoso-ciliated and aureo-villous along the mid-rib 
and nerves, and appresso-pubescent beneath: petiole short, compressed. l'eduncles about six together, below and close to the cluster of young leaves, nearly an inch in length, compressed, aurco-!omentose, each bearing a globular head of flowers, penciulous: flowers small, yellowish, very shortly pedicelled, inserted into sma!l excavations at the extremity of the peduncle. Calyx urceolate, edentulous or obscurely 5 touthed. Stanens 10, erect, inserted on the sides of the calyx; 5 of them scarcely longer than the calys; the other s nearly twice the length. Ovary villous; style length of the longer stamens; stigma acuts. Drupe size and shape of an clive, green, oblong; nut oblong, compressed, hexangular, 1-celled, 1-seeded.

This tree sheds its leaves, and at the same time the fruit drops, early in the year, and for a time the branches remain naked. The young leaves, which lave a silky russet appearance, and the flowers, are produced during the months of May and June. This tree, according to Robinson has reccived the name of Nerressee trom the Negroes. The bark has an aromatic astringent bittar taste, and a decoction of it, we are informed, has been employed as a remedy for the complicated discases, resembling constitutional syphilis, to which the African race is so subject. The word is of a yellow colour, is durable, and, being of a close grain, takes a fine polish. It is employed to make bedsteads, and other furniture.

\section{Terminalia.}

Flowers, by abortion, generally polygamous. Limb of the calyx deciduous, bell-shajed, 5-fid with the lobes acute. Petals $\bigcirc$. Stamens 10, biserial, longer than the calyx. Ovary bi-ovuled; style filiform, subacute. Drupe not crowned with the calyx, generally juiceless, indeliscent, one-seeded; seed amygdaloid; cotyledons spirally convoluted.-- $D C$.

Trees or shrubs, natives of the Tropics. Leaves usually in bunches at the termination of the branches. Flow. ers in a spike: spikes racemose or panicled; $\Varangle$ flowers situated at the lower, of at the upper portion of the spike. - Named from the leaves being collected in clusters at the termination of the branches. 


\section{Terminalia Catappa, St. Helena Almond.}

Leaves elongato---obovate in the adult subglabrous (ferrugineo--pubescent on the under surface in the young leaves), an obscure glandule on each side of the mid-rib towards the base, drupe compressed.

Amygdalus Indica, Raii Hist. 1521.--Terminalia Catappa, Jacq. Ic. Rar. t. 197.--Hooker, Bot. Mag. t. 3004.

H A B. Cultivated. Common.

F L. June-August.

A Tree, 30-50 feet in height. Leaves 6-12 inches long, with the margin thickened, and involuted beneath towards the base, and in the young leaves provided with minute brown glandular deciducus teeth. Disk of the calyx internally villous, persistent. Stamens; 5 of them opposite to the calycine lobes, with their insertion low in the calyx; the 5 in the indentations with their insertion higher, and hence they are apparently longer: filaments white, glabrous; anthers ovate, yellow. Ovary villous. Fruit about 2 inches in length, ovali-orbiculate, compressed, almost winged at the edges.

According to Sir William Hooker's observations on a flowering specimen obtained from the Liverpoul Botanic Garden, the leaves are, especially on the under surface, pubescenti-tomentose. This may be ascribed to the circumstance of their having been produced in a close Hothouse, where the downy covering, which is deciduous, would be much longer retained, than in the open air exposed to the breeze and the rain.

This Tree is a native of the East Indies, the Isle of France, \&c. It was introduced into this Island from St.

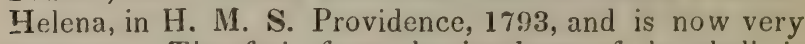
common. The fruit. from the hardness of the shell, is scarcely ever made use of. We are informed howerer, that it is served up at the first tables in India, and that the Natives, obtain an expressed oil, and make an emulsion from the kernels, and employ an infusion of the leaves as a remedy in cholic. The taste of the fruit resembles that of the sweet almond. The wood is white and hard. The tree itself is very ornamental; the stem erect, and the branches sprearing horizontally. It has a very remarkable and beautiful appearance previous to shedding 
its leaves, which at that time change to a deep blood red colour.

\section{Terminalia latifolia. Broad Leaf.}

Leaves alternate obovate obtuse glabrous eglandulose, drupe fleshy ovate cymbiform.

Arbor maximn. forte prunifera, cortice cannabino, folio longissirno latissimoque, Slorne, II, 130.-Terminalia latifolia, Swartz, Fl. Ind. Occ. 747.

I A B. Manchester. North-Side

F. L. May.

A lofty forest-tree. 80-!00 feet in height. Stem straight, 40.c0 feet before giving off a branch, 2-3 yards in diameter; bark thick, sulcated, ash-coloured, coming off in long peces: branches horizontal. Leaves in clusters at the end of the branches, werge shaped at the base, large, 810 inches leng, and 4 broad near the point: petioles of moderate length, terete, thick. Racemes terminal, produced from the axils of the leaves, and of the same length, solitary, erect, many-flowered. Flowers crowded, sessile, small, whitish, polygamous. $\Varangle ~ F l s$. occupying the lower part of the raceme. Drupe large, ovate, acuminate, cymbiform (with one side slightly compressed, the other more convex) coriaceous, when ripe greenish-red, sweet: nut very hard: kernel ovate, very white, with the taste of the sweet almond. of Fls. smaller, more numerous, deciduous. Pistil $\bigcirc$.

This is a very common tree in certain districts. The timber is valuable, and it splits readily into shingles, which last from twelve to fifteen years. I have been informed that the bark is adapted for tanning leather.

\section{Terminalia arbuscula, Dwarf Broad Leaf.}

Leaves scatter ed ovato-lanceolate entire shortly petiolate, younger leaves pubescent, afterwards glabious, spikes length of the leaves.

Swartz, Fl. Ind. Occ. 750.

H A B. Mountain districts, Northside.

F. L. - ?

A shrub, an ell in height. Stem erect, very much branched, sinooth. Leaves situated principally at the 
ends of the branches, Racemes terminal, axillary (?), solitary, many-flowered, length of the leaves, erect ; flowers sessile, minute. Calyx 5-toothed, internally villous contracted towards the limb, urceolhte. Stamens 10, exserted. Fruit unknown.

This species must be rare. It does not appear to have been met with by any Botanist, with the exception of Swartz.

\section{Conocarpus. Button Tree.}

Calyx 5-fid, deciduous. Petals $\bigcirc$. Stamens 5-10, exserted: anthers cordate. Ovary compressed, bi-ovuled: style 1, simple. Fruit suberose, coriaceous, scale-likc, closely imbricated, indehiscent: seed 1, pendulous; cotyledons involuted.

Trees or shrubs ; leaves a!ternate, entire: flowers small, yellowish, in heads. Naine from kovos a cone, and картоя a fruit.

\section{Conocarpus erecta. Upright Button Tree, or West India Alder.}

Leaves lanceolate attenuated at both ends frequently biglandulose at the base, heads of fluwers racemed.

A!ni fructu, laurifolia arbor maritima,, Sloane, II. 18. t. 161. f. 2.-Rudbeckia laurifolia maritima, Anun. Herb. 581.-Innominati, Plum. Ic. 135. t. 144, f. 2.-Alnus mariłıma, Pluk. alm. 18. t. 140. f. 3.-Conosarpus Manghana, Catesb. Cur. 11. 33. t. 33.-C. erecta, Jacq. Amer. 78. t. 52. f. 1.

II A B. Common along the sea-shore.

F. L. Autumn.

$\Lambda$ low tree, 1030 feet in height, much branched: brancoes coloured, towards the extremity angulose, green, glabrous. Leaves irregularly alternate, lanceolate, acuminate at both ends, eitıre, thickish, almost nerveless, glabrous. greasy to the touch: petiole short, occasionally with a sessile subrotund depressed glandule at the base of the attenuated portor of the leaf, somutimes on one, at 
other times on both sides, or not unfrequently awanting. Racemes terminal, solitary, longer the leaves: flowers collected into a peduncled globular head, minute, sessile, ye!low. Calyx 5-fid divisions small, erect, acute. Stamens 5, of the same length as the calyx, alternating with its divisions. Ovary compressed: style twice the length of the calyx: stıgma obtuse. Fruit orbiculate. scale-like, closely imbricated, compressed, concave on one side, convex and incano-tomentose on the other or outer side; margin expanded: seed lanceolate.

This 'I'ree has recelved the name of Zaragoza Mangrove, from the Spaniards. It is common along all the shores of the Islands and Continent of 'Tropical America.

\section{Laguncularia.}

Calyx persistent, subcampanulate, 5-partite ; lobes obtuse. Pefals 5, minute, patulous, caducous. Stamens 10, in two rows, included. Style subulate: stigma capitate. Nut margined, coriaceous, crowned with the calyx, valveless, oneseeded: cotyledons convolute; radicle very long.

There is only one species hitherto referred to this genus. - Name, derived from Laguncula a pitcher, the fiuit having some resemblance in figure to a vessel of that description.

\section{Laguncularia racemosa, White Mangrove.}

Mangle julifera, Sloane, II. 65. t. 18\%. f. 1.--Conocarpus, Browne, 159 -C. racemosa Jacq. Amer. 80. t. 53.Swartz, Obs. 79.-Liaguncularia, Gertn. f. Carp. 209. t. 217 .

II $A B$. Common in marshy situations, near the sea. side.

F. L. October.

A shrubby tree, about 12 feet in height, branching low down in the stem: branches upposite, slightly compressed towards the extremities, glabrous, coloured. Leaves opposite, shortly petiolate, elliptic, rounded at the apex, subemarginate, entire, glabrous, greasy to the touch, obscurely penninerved: pstiole biglandulose near the leaf. Raceme terminal, usually dividing near the base into three branches; the lateral branches opposite and simple; 
the centre branch sub-divided into three branchlets, which are simple, the central one beirg the longest. Peduncle and its divisions compressed, minutely puberu. lous. Flowers sessile, white, with a fairit but not unpleasant odour; each with an ovate concave deciduous brac. tea. Calyx externally puberuious, with a pair of minute lanceolate bracteoles at its base. Petals very small, alternating with the calycine segments, rounded, concare, minutely puberulous, caducous. Stamens 10. Ovary compressed, obovate, incano---puberulous, malked with 10 striæ: seed 1, germinating within the nut.

This is a cominon tree in most of the sandy bays, and along the margin of lagoons throughout the Island. The Spaniards call it MANGLE BoBo or foolish mangrove. It is known in this country as the white mangrove. The bark possesses tanning properties, though not in a very powerful degree. Mr. Bell, who has conducted a Tannery in the vicinity of Kingston for many years, informs me that he finds it useful when conninind with the pods of the Divi divi, in order to qually the too active tanning principle of the latter.

\section{Tribe II. Combreter.}

V. Combretum.

Calyx infundibul:form, 4-lobed, deciduous. Petals 4. Stamens \&, biserial; the $\mathbf{4}$ which are opposite to the petals being higher in their insertion, and much exsertel. Uvary 2-a-ovuled. siyle exserted, acute. Fruit 4-winged, 1-celled, 1seeded, indehiseont. Seed ang'ed, pendulins: cotyledons with a miludie fold, relexed, cruciatodivaricated.

Subscandent shrubs or trees. - The name Combretum was given to a climbing plant by Pliny.

\section{Combretum laxum. Red Withe.}

Unarmed scandent, leaves opposite oval acuminate glabrous, spikes opposite ebracteated, the terminal one peduncied, calyx internally villous, fruit 4-winged.-DC. 
Swartz, Obs. 143-Jacq. Amer. 104.

II A B. Thickets, at the West end of the Island.

F. L. December.

A scandent shrub, with a strong stem about tivo inches in diameter, reaching to the heiglit of 30-50 feet, supporting itself on neighbouring trees: the bark of a reddish brown colour, and hence the common designation. Leaves large, 5-10 inches in length, entire, strongly nerved, glabrous. Flowers numerous, pedirelled, small, albo-lutescent in colour. Petals 4, shortly clawed. Capsule oblong, tetragonal, quadri-alate, 1-celled; sceds quadrisulcate, rugose.

Dr. Anthony Robinson, in his manuscript work, mentions that this plant is common in the woods and morasses near Paul-Island, Westmoreland.

\section{ORDER LXX. RHIZOPHORER.}

Calycine tube adhering to the ovary; limb 4-13-lobed. with the lobes valvate-Petals inserted on the calyx, alternate with its lobes. Stamens inserted with the petals, of the same number, or its multiple: filaments free, subulate: anthers ovate, inserted at the base. Ovary bilocular: cells bi-or multi-ovuled, with the ovules pendulous. Fruit indehiscent, crowned with the calyx, 1-celled, 1-seeded: seed pendulous, exalbuminose: radicle long: cotyledons 2 , flat.

Intertropical trees or shrubs, growing along the sea coast, rooting in the mud, forming a dense thicket wherever there is marsh or lagoon.

\section{Rhizophora.}

Calycine tube obovate; lobes 4-13, oblongolinear, persistent. Petals of the same number as the lobes, oblong, biaristate at the apex, convoluted. Stamens of the same number as the 
petals. Style bifid at the apex. Fruit crowned with the calyx, indehiscent, 1-seeded : seed small: embiyo inverted, germinating, protruding for some length from the seed.

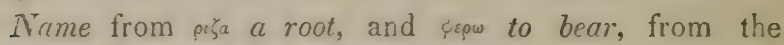
branches throwing down roots very free! y, which descend into the mud, so that every uranch is supported by its own root, and the tree exiends over a considerable space.

\section{Rhizophora Mangle. The Mangrove.}

Leaves obovato-oblong obtuse, peduncles 2-3 flowered loinger than the petiole, fruit subulatoclavate.-DC.

Mangle pyri foliis, cum siliquis longis ficui indici affinis, Sloune, IJ. 63--Candela Americana toliis laurinis, Catesb. Car. II. 63. t. 63.--Rhiz phora Mangle, Jacq. Amer. 141. t. 89.

II $A$ b. Marshy grounds and Lagoons near the Seashore.

F. L. Throughout the year.

A tree $20-40$ feet in height: branches 3 chotomous, terete, glabrous, ash coloured, shining. Leaves somewhat truncated at the ap $\mathrm{x}$, subcoriaceous, smooth, shining, with a somemnat greasy feel, dark green above, paler beneath, and marked with minute dark excavated dots: petiole compressed. Peduncles axillary, 2-4-5-flowered, with a pair of small ovate appressed bracteæ below each flower, and to each division of the peduncle. Calyx deeply 4-cleft; lobes acute, internaily 3-nerved, persistent. Petals 4, lanceolate, shorter than the calyx, internal!y hairy, caducous. Stamens 8 , iuserted at the junction of the filaments with the anthers: filaments capillary, free, erect: anthers lanceolate, b.locular; with the locules of a cellular texture. Ovary conical, 4-ovuled; style subulate, bifid: stigmata simple. Fruit ovato-oblong, thick, fleshy, toward the lower extremity crowned with the reflected lobes of the calyx, pierced at the apex tor the passage of the seed, whose base alone it contains: seed single, very long, round, thickened toward the end,

It is the remarkable character of this tribe of p'ants that the seeds germinate while they are still attached to the branch that bears the fruit. The radicle and club-shaped 
crown of the root gradually lengthen until they reach the soft muddy soil, or, if too high, drop, and. fixing themselves in the muddy bottom, immudiately strike root at one end, while leaves unfold at the other.

The Mangroves form thickets along our sea const, wherever there is marsh or lagoon. They are far from adding any beauty to the landscispe: on the contrary, they give a gloomy desolate appearance, and are assoriated in our minds with ideas of malaria, and disease. The presence of these trees indeed is a sure indication of the unhealthiness of a locality. Certain situations along the sea coast have been found to be healthy. The soil in such places will be found to be dry and porous, and, above all, no mangrove trees will be found in the immediate vicinity. The shade they afford is not dense, but the thicket they form is not easily penetrated, from the roots that are sent down from every branch. These roots are rather thicker than the thumb, round, smooth, simple, straight. They do not, as far as my observation goes, become thicker in course of time, so as to assume the appearance and function of stems. Such however would, I have no doubt be the case, were the original stem destroyed. When they reach the mud, they throw out numerous fibres, or ruotlets, and thus furnish a more copious and additional sup. ply of nourishment to the tree. By this interlacing of the roots, they doubtless serve to detain the mould washed down by floods, and thus assist in converting useless and pestiferous ponds or marshy grounds, into rich and fertile lands.

The bark of this tree, is known as the red Mangrove. It is much employed for tanning. It is stronger than oak bark, and is well adapted for the preparation of sole leather.

\section{Cassipourea.}

Calyx campanulate, 5-fid. Petals 3, attenuated at the base, with the margin or apex fimbriato-lacerated. Stamens 20-40, inserted at the base of the calyx, arranged in a single row. Style longer than the stamens: stigma obtuse. Fruit covered with the calyx, 3-celled, 3-valved, with the cells bi-ovuled, but by abortion one-seeded. 
Tress or shrubs. - Name of Indian derivation, given by Aublet.

\section{Cassipourea elliptica.}

Leares elliptic acuminate at both ends shortly retiolated very cntire, flowers distinctly pedicelled, petals subpalmato-fimbriated.

Legnotis elliptica, Swartz, Fl. Ind. Occ. II. 969, t. 17. -Cassipourea elliptica, DC. Prod. III. 31.

H A B. The lofty mountains.

F L. May and June.

This must be a rare tree, as it has been described by no Botanist, with the exception of Swartz-The follow. ing is a brief description:

A tree 10-30 feet in height. Leares opposite, petiolate, scarcely nerved, very glabrous, somewhat stiff. Stipules small, ovate, membranaceous, deciduous. Flowers axillary, peduncled, 3-5 together; peduncles 1-flowered, generally shorter than the petiole, furnished at the insertion with minute imbricating squamules. Calyx internally cano-tomentose; divisions ovate, acute. Petals longer than the calyx, deciduous: claw linear; border with the divisions linear, incarnate, with a white villısity, Ovary subrotund pubescent, encircled with a fleshy annular disk. Capsu'e large, 3-gonal: seed solitary.

\section{ORDER LXXI. ONAGRARIE.}

Tube of the Calyx adnate partially or entirely to tho ovary; limb 2-5 lobed, frequently 4-lobed; æestivation valvular. Petals of the same number as the calycine lobes and alternating with them; rarely none. Stamens of the same number as the petals, or double. Ovary 2-4-celled, crowned with a disk: style filiform: stigma capitate or lobed. Fruit capsular, berried, or a drupe, 2-1colled. Sceds numerous in each cell : albumen 
none; embryo straight; radicle long and taper; cotyledons short.

Herbaceous or shrubby plants. Although they are chiefly natives of temperate regions, several species are indigenous to this island.

\section{Enothera.}

Calycine sepals 4, coalescing to form a long tetragonal or eight-ribbed tube, with the limb and part of the tube caducous. Petals 4. Stamens 8 , erect or declinate; pollen triangular, viscid. Stigma 4-cleft or spherical. Capsule oblongolinear, obtusely tetragonal or obovato-clavate, 4celled, 4-valved, many-seeded. Seeds attached to a central placenta.

Herbaceous or suffruticose plants. Leaves alternate, laciniated, or pinnatifid. Flowers yellow, or more rarely orange or purple._-Nrme, from orvos wine and onpw to pursue; the roots of the anothera biennis, having formerly been employed, like olives in the present day, as an incentive to wine-drinking. It may also be ascribed, to the flower opening at vight, the usual period of day devoted to wine-drinking.

\section{Enothera longiflora, Long-flowered Evening Primrose.}

Stems simple hairy, leaves denticulated, petals bi-lobed distant, calycine tube very long, stigmata very long thickish, stamens shorter than the corolla, capsules linear very long hirsute.

H A B. Common, St. Andrew's mountains.

F I. June,

Biennial. Root thickness of the thumb, sending up about 5 simple hairy stems. The radical leaves obovato-lanceolate, attenuated at the base along the petiole, denticulated, ciliated, hairy especially along the mid-rib, about four inches long: cauline leaves sessile, oblong, acute. Calycine tube about thrice the length of the limb. 
Flower rather larger than that of the common evening Primrose, yellow, but acquiring on the second day a red ish tinge.

This is a very common plant in the above locality. It ma! however have been an introduced plant. Buenos Ayres is said to be its native country.

\section{Enothera rosea. Rose Enothera.}

Stem suffruticose branched, leares, the lower ones lyrate, the upper ones ovato-lanceolate dentate, tube of the calyx short, petals ovato-subrotund, stamens of nearly the same length as the petạls, capsules clavate octangular.

E. purpurea, Lam, Dict. IV. 534.--CE. rubra, Carv. Icon. IV. 68. t. 400.--E. rosea, Hort. Kew. II. 343.Bot. Mag.

II A B. Common, in the mountains of St. Andrew, PortRoyal, and St. David, especially in Coffee pieces.

F L, Throughout the year.

Suffrutescent, about a foot in height: branches from the root, subsimple. virgate, terete, puberulous, coloured. Leaves alternate, the lower ones subsessile: the upper ones ovato-lanceolate, acute, undulated, irregularly dentate, nerved, glabrous above, minutely puberu'ous especially along the nerres beneath. Sitipules (?) foliaceous, lanceolate. Inflorescence subracemose: common peduncle 8 inches in length, puberulous, about 10 flowered: flower pedicelled, rose-colsured. Tube of the calyx about three lines in length: divisions of the limb 4, cohering at the apex. Petals rounded, rose-coloured, with a greenish spot at the base. St: mens 8: anthers linear. Stigma 4-cleft. Capsule clavate, 4-sided, 8-ribbed: seeds minute.

This also is an excerdingly common weed in the above Incalities, an 1 is plentiful in the Yailah's and Hope Rivercourses. It is noticed by De Candolle as a native of Mexico.

\section{Jussiza.}

Calycine tube adherent throughout to the ovary : limb 4-3 partite, with the lobes acute persist- 
ent. Petals of the same number as the Calycine lobes, patent. Stamens twice the number of the petals, deciduous with the petals. Style short, filiform: stigma capitate, 4-6.sulcated. Capsule 4-6-celled, oblong, crowned with the calyx : seeds very numerous, naked.

Herbaceous plants, rarely shrubby, natives of marshy situations. Leaves alternate. Flowers axillary, solitary, sessile or shortly peduncled, yellow, rarely white.Namell by Linnæus in memory of Antoine de Jussieu, Demonstrator of plants in the Royal Gardens at Paris, and uncle of the celebrated Antoine Laurent de Jussieu.

* Pentapetalous, decandrous.

\section{Jussiæa Swartziana, Swartz's Jussiøa.}

Herbaceous creeping glabrous, leaves oblongo -obovate somewhat hlunt, flowers pedicelled bicallose at the base, calycine tube roundish attenuated at the base, lobes 5 lanceolate acute of nearly the same length as the obovate petals.

Enothera herbacea repens, Browne, Jam. 20s?--Jussieua repens, Swartz. Obs. 172,--Jussiæa Swartziana. DC. Prod. III. 54.

HA B. In marshy wet land. Common along the margin of the Lagoon, Ferry-road.

FL, September.

Stem procumbent, rooting towards the base, afterwards ascending. Leaves alternate, petiolate, obtuse, at:enuated at the base un inch and a half in length. Pedun. cles nxillary, solitary, of the same length as the petiole, one-flowered: a pair of minute sub-opposite callous.like brarteoles beneath the ovary. Flowers yellow. Calycine tube adhering to the ovary, terete, striated : lobes $\overline{5}$, lanceolate, of nearly the same length as the petals. Petals 5, obovate, rounded. Stamens 10. Style erect; stigma capitate; an annular hairy glandule crowning the ovary, on which the stamens are inserted. Capsule about an inch in length, oblong, crowned; seeds nume. rous, angulated, longitudinally arranged in five rows. 
This species is to be found in marshy situations, throughout the West India Islands, such as in Hayti and Porto Rico, Sloane remarks that the flowers "make a fine show ; it grows in mud." Browne mentions the low ground of $\mathbf{P}$ antain Garden River as a locality. There appears to be little to distinguish it from J. REPENS, a common plant, in dar.p grounds, in different parts of the East Indies. 'The principal differ nce is, that in this last named plant, the calyx is subhirsute.

\section{* Tetrapetalous octandrous.}

\section{Jussiæa acuminata. Sharp-pointed leaved Jussiaa.}

Herbaceous ascending somewhat erect subsimple glabrous, leaves shortly petiolate lato-lanceolate acuminate at both ends, fliwers shortly pedicelled ebracteolated, calycine lobes 4 ovatolanceolate, petals acute patulous.

Swartz, Fl. Ind. Occ. 745.--Meyer, Prim. Ess 173.

H A B. Low damp situations, on the South-side.

F L. Novernber, December.

Herbaceous. Stem decumbent at the base, afterwards ascending, tetrangular, glabrous, about 6 inches in height. Leaves very glabrous, thin: petioles sho:t; the lower ones longer. Flowers axillary, very shortly peduncled, solitary, small. yellow. Petals 4, acuminate, caducous. Stamens eight, shorter than the petals, capillary. Style short, thick : stigma capitate, large. Capsule half an inch in length, tetragonal, a uminate at the base, 4-celled: seeds very numerous and minute.

\section{Jussiæa erecta. Erect Jussiaa.}

Herbaceous erect branched subterete, branches somewhat angular, leaves shortly petiolate lanceolate acuminate at hoth ends, flowers sessile eluracteated, calycine lobes $\mathbf{4}$ acuminate nearly cqual to the obovate petale, capsule tetragonal roundish constricted under lie limb of the calyx. 
Lysimachia lutea erecta, Sloane, I. 37. t, 11. f. 1.--Jussiua erecta, Swartz. Obs. 173-Jussiæa erecta, DC. Prod. III, 5.

\section{H A B. Damp pastures.}

if L. Spring.

Stem herbaceous, 2-4 feet in height, erect, branched, glabrous, rubescent. Leaves lanceolate, acuminate: petioles very short, red. Flowers axillary, solitary, yellow, rather small. Calycine lobes ovato-lanceolate, acuminate, spreading, glabrous. Petals 4 , remote, entire, deciduous. Stamens 8 , shorter than the petals, erect: anthers diminutive, whitish. Style very short: stigma capitate. Capsule elongated, half the length of the leaf, tetragonal, 4-celled, $\mathbf{4}$-valved : seeds very minute.

\section{Jussiæa octonervia. Eight-nerved Jussica.}

Herbaceous erect glabrous except the ends of the branches which are pubescent, leaves angustolanceolate acuminate, flowers sessile, calycine lobes 4 lanceolate acute, tube cylindrical 8-nerved shorter than the floral leaf, petals obovate emarginate larger than the lobes of the calyx.

Enothera assurgens glabra Browne, Jam. 208.Enothera octonervia, Jacq. Amer. 102. t. 70.-Jussiæa octonervia, DC. Prod. 11l. 57.

H A B. Marshy ground : river courses.

F L. April.

Stem 3.4 feet in height: branches terete, erubescent, glabrous, 6-lineated; towards the extremity compressed, hexangular, and puberulous. Leaves lanceolate with an apicula, attenuated at the base, minutely puberulous and ciliated, and pellucido-punctulated alung the margin: petiole short. Flowers axillary, solitary, sessile, rather large, yellow, ebracteolated. Calycine lobes lanceolate, attenuato-acuminatê, 5-7-nerved, minutely puberulous externally, and ciliated. Petals three times larger thin the calycine lobes, broad-obovate, emarginate, veined, deciduous. Stamens 8. Style short, thick, half the length of the calycine lobes, conical at the base and tetragonal, with a villous arched line corresponding to the insertion of each alternate filsment: stigma large, capitate. Capsule 2 inches in lenght, attenuated, slightly curved and 
seedless at the base for three fourths of an inch, 8-nerved with the nerves persistent, and at length filiform.

There appears to be very little difference between this species and the following, except that the latter is said to be pubescenti-villous, and the flowers pedicelled and bibracteolated.

\section{Jussiæa octofila. Eight-threaded Jussiaa.}

Herbaceous and pubescenti-villous, leaves lanceolate acute, flowers shortly peduncled bibracteolated at the base, calycine lobes 4 ovate acuminate 3-nerved, tube cylinùraceous somewhat attenuated at the base 8-costate, petals subrotundo-obcordate three times larger than the calycine lobes.

Jussiæa octovalvis, Swartz, Obs. 142.-Jussiæa octofila. DC. Prod. III. 57.

HAB. Common in damp pastures, and cane-piece in. tervals.

F L. November.

Erect, 2-3 feet in height: branches subtetragonal. pubescenti-villous. Peduncles axillary, solitary, one-flowered, half an inch in length. Bracterles two, small, subulate, at the base of the ovary. Calycine tube linear, subtetragonal, villoso-pubesc $n$ nt: lobes 4 , ovate, slightly acuminate, 3-nerved, externally pubescent. Petals 4, subrotundo-obcordate, $\mathbf{3 . 4}$ times larger than the lobes of the calyx. Filaments short: anthers versatile: the in. sertion of each alternate stamen marked with an arched villous line. Style short: stigma large, capitate. Capsule two inches in length: nerves eight, peisistent, and filiform: seeds numerous.

It may be remarked that the petals in this species are not so ciducous as in the former. There is also a distinct peduncle.

\section{Jussiæa hirta. Hairy Jussiæa.}

Suffutescent erect hirsute, leaves very shortly petiolate lanceolate attennated at the base, hairy 
on the under surface, peduncles short ebracteolated, calycine lobes 4 ovate acute 5-7-nerved at the base, tube obconical subcylindraceo-ovate 4nerved, petals obovate longer than the calyx.

Lysimachia lutea erecta, major, foliis hirsutis, fructu caryophylloide, Sloane, Jam. 85.-Enothera assurgens hirsuta, Browne, Jam. 208.--Onagra frutescens et hirsuta, flore magno flavo, Plum. Spec. 7. ic. 174. f. 2.-Jussieua hirta, Swartz, Obs. 143.

H A B. In damp meadows.

F L. Early in the year.

Branches towards the end hexangular, hairy. Leaves irregular in situation, ovato-lanceolate, attenuated at the base. Flowers rather large, yellow, axillary, shortly peduncled. Caly $x$ externally hirsute. Petals 4 , rounded. slightly obcordate. Base of the style, with an arched line of villous hairs, corresponding to the insertion of each alternate stamen.

\section{ISNARDIA.}

Calycine tube ovate or short, adherent to the ovary : limb 4-partite, persistent. Petals either 4 , alternating with the divisions of the calyx, or rudimentary or none. Stamens 4, opposite to the calycine lobes. Style filiform, deciduous: stigma capitate. Capsule obovate or almost cylindrical, tetragonal, 4-valved, 4-celled, many seeded.

Aquatic or marsh herbaceous plants.--Name given by Linnæus in the honor of Antoine Dante lsnard, member of the Academy of Science.

\section{Isnardia repens. Creeping Isnardia.}

Stem rooting tetragonal glabrous, leaves opposite obovate, or ovate and attenuated towards the base, peduncles axillary shorter than the petiole, petals ovate much smaller than the calyx, capsule oblong tetragonal. 
Oldenlandia aquatica, foliis obovatis oppositis, floribus singularibus ad alas, Browne, Jam. 146.-O. uniflora, Willd. Sp. I. 675.--Ludwigia repens, Swartz, Fl. Ind. Occ. I. 273.--Isnardia repens, 1 C. Prod. III. 60.

II A . The banks of still flowing streams. Very common in the Ferry River.

F L. Throughout the year.

Stem creeping, sparingly branched, 1-2 feet in length, tetragonal, sending out fibrillæ at the joints, glabrous, coloured. Leaves shortly petiolate, subacute at the apex, acuminate at the base, very glabrous, erubescent. Pedicels solitary, shorter than the petioles, 1-flowered. Flowers small. A pair of lanceolate bracteoles at the base of the ovary. Calycine lobes 4, acute. Petals 4, much smaller thin the segments of the calyx, ovate, clawed. Capsule oblong, tetragonal: seeds many.

\section{ORDER LXXIII CERATOPHYLLEF.}

Flowers monœcious. Calyx inferior, 10-12partite. Petals none. o Stamens 12 to 20. ? Ovary superior, 1-celled; style pervious : stigma oblique. Nut 1-seeded, indehiscent, terminated by the hardened stigma: seed solitary; albumen $\bigcirc$; embryo dicotyledonous ; plumule many leaved; radicle inferior.

The ovary being superior, it is evident that this Order is misplaced. It has been made by Dr. Lindley to follow the URT:CEe. As I have commenced, however, with the arrangement of DeCandolle, I will not depart from it on the present occasion.

This order comprises only one Genus; and, that but few species. The plants have been found in ditches and in slow flowing streams, growing under water, in almost every part of the worid. Leaves whorled and finely dissected. 


\section{Ceratophyllum.}

Character the same as that of the Order.--Name from

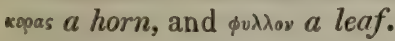

\section{Ceratophyllum demersum. Morass-weed or Hornwort.}

Nut 3-seeded, one being terminal and iwo lateral.

Browne, Jam. 345.

II B. Common. The Lagoon near the Ferry.

F L. Throughout the year.

This is a very common plant in stagnant or slow flowing water. It is commonly used to cover up fish ; the moisture, with which the plants are loaded, preserving the fish cool and fresh.

\section{GRDER LXXIV. LYTHRARIEA.}

Calyx monosepalous, tubular, ribbed; lobes with a valvate or separate rstivation. Petals inserted between the lobes of the calyx, very deciduous, sometimes wanting. Stamens inserted on the tube of the calyx, below the petals, to which they are either equal, or 2,3 , or 4 times the number : anthers adnate, 2-celled. Ovary superior, 2-4-celled. Capsule membranaceous, covered by the calyx, usually 1-celled, longitudinally dehiscent, or circumscised in an irregular manner: placenta central : seeds numerous, small, without albumen: embryo straight: radicle turned towards the hilum: cotyledons plane, leafy.

The Plants belonging to this Order are usually herbaceous, rarely frutescent. Few of them possess any pro-

Vor. 2. 
perties deserving of notice. The Lagerstromia Regina, a tree about 30 feet in height, and Lagers'rR EMIA INDica, are common in our gardens, and rank among the most showy of our ornamental plants. Lawsonia Alba, the plant from which the Henna or Alhenna of the Arabs is procured, known here as the Tree Mignionette, from the powerful odour it exhales at night, is also very generally cultivated. The bark and leaves of Lagerstremia REGINe are accounted purgative and hydragogue, and the seeds narcoic.

\section{Ammannia.}

Calyx bell-shaped, tenth 4-7, erect, with smaller horn-like patulous teeth at the indentations. Petals none, or 4-7, alternate with the erect teeth, Stamens of the same number or half that of the teeth of the calyx. Capsule ovato-globose, membranaceous, 4-celled, or when ripe 1-celled.

Glabrous aquatic herbaceous plants. Flowers axillary sessile or shortly peduncled, small.-Name, in honor of John Amman, a Botanist and Physician at St. Petersburgh.

\section{Ammannia latifolia. Broad-leaved Am- mannia.}

Stem tetragonal erect branched, leaves linearilanceolate obtuse cordato-auriculated, flowers axillary 1-3 sessile furnished with petals (?) and stamens.--DC.

Aparines folio anomala, rasculo seminali rotundo. Sloane, Hist. I. 44. t. 7 f. 4.--Isnardia foliis sessilibus lanceolatis quasi auritis, floribus ternis, Browne, 148.

H A B. Marshy places. Near the Ferry.

F L. After the May rains.

Stem with obtuse angles, with the opposite sides alternately convex, sparingly branched. Leaves two inches in length. Flowers 3-5, verticillate. Petals white or none.

This plant deserves better examination. 


\section{Ammannia Sanguineolenta. Blood-stained Ammannia.}

Leaves lineari-lanceolate subacute cordatoauriculated semiamplexicaul, flowers axillary 1-3 subsessile, petals 4 , stamens 8 .

Swartz, Fl. Ind. Occ. I. 272. Bay.

H A B. Ditches and marshy grounds. Near Annotto-

F L. After rains.

Stem herbaceous, erect, about six inches in height, glabrous : branches subsimple, tetragonal with the opposite sides alternately sulcated. Leaves opposite, distichal, sessile, semi-amplexicaul, very glabrous. Flowers small, crimson, crowded in the axils of the leaves, 35 , very shortly pedicelled. A pair of minute bracteæ to each flower. Calyx minute, 4-sided. 8-toothed, with four of the teeth erect, and the other 4 directed outward. Petals 4, clawed, small, deciduous. Stamens 8 , length of the corolla : anthers yellow. Style erect, curved, longer than the stamens. Capsule partially covered with the calyx, spherical, bursting at the side, 4-celied, many seeded.

\section{Cuphea.}

Calyx tubular. 12-ribbed at the base, gibbous on the upper side ; teeth 6 , erect, with a corresponding number of little processes in the indentations.

Petals 6-7, unequal. Stamens 11-14, rarely 6-7, inserted on the throat of the calyx, unequal. A thick glandule under the ovary: style filiform: stigma simple or slightly bifid. Capsule membranaceous, covered with the calyx, 1-2-celled, early opening at one side: seeds suborbiculate, compressed, wingless.

Herbaceous or shrubby plants. Peduncles interpetiolar. Calyces coloured. Petals violet or white.--Name from кupos curved, in allusion to the shape of the calyx. 


\section{Cuphea viscosissima. Clammy Cuphea.}

Stem herbaceous erect branched pubescentiviscid, leaves opposite petiolate ovato-oblong slightly scabrous, flowers axillary pedicelled solitary deflected, calycine teeth 6 pubescentiviscid, petals 6 unequal, stamens 12.

Jacq. Hort. II. 83. t. 177.-A. Gray's Manual 134.

II A B. In shady damp places, vicinity of Bath.

F L. Throughout the year.

About 6-12 inches in height; branches purpurascent. Flowers purple, decumbent. Calyx subcylindrical, 12 striated, opening with a lingitudinal rupture for the passage of the seeds previous to their becoming ripe. Capsule bursting laterally corresponding to the rupture of the calyx : seeds rather large, borne on one side of the placenta.

This is not uncommon in the neighbourhnod of the Bati Garden, as well as of that in St. Andrew's.

\section{Cuphea Parsonsia. Procumbent Cuphea.}

Stem herbaceous prostrato-ramose subscabrous, leaves opposite shortly petiolate oval acute at both ends, as also the calyces, glabrous, flowers axillary solitary subscssile, petals jo oblong subequal, stamens 6, with two somewhat longer.

Parsonsia, herbacea, Browne, 199. t. 21. f. 2.-Lythrum Parsonsia, Swurtz, Obs. 193.-Cuphea Parsonsia, $\boldsymbol{R}$. Brown, and Steud. nom. phan. 245.

II A B. In damp rocky places. In pastures.

F. L. Throughout the year.

Stem prostrate: branches simple, suhflexuose. Leaves small, very entire, glabrous. Flowers small, pale, red. Capsule 4-6 seeded.

\section{Cuphea Melanium. Alternate flowering Cuphea.}

Stem herbaceous prostrate pubescent at the apex, leaves opposite subsessile elliptic acumi- 
nate at both ends, flowers solitary axillary subsessile alternate, petals 6 oblong, stamens 8-10 unequal.

Melanium herbaceum, Brrwne, 217,-Lythrum Melanium, Swartz, Obs. 193.-Cuphea Melanium, R. Brown and Steud, nom. phan. 245.

II A B. Sparingly in cultivated grounds.

F. L. Throughout the year.

Stem about a foot in length, subdivided, prostrate, as. cending. Leaves larger than in the last species, very entire, somewhat scabrous. Flowers purple, larger than in C. Parsonsia. Calyx 6-10-toothed. l'etals 6, ovate, obtuse, deciduous. Filaments uncqual: anthers cordate. Style subulate: stigma acute. Capsule oblong: seeds 4.6, emitted through the ruptured opening in the calrx.

This species is remarkable, from a flower being placed in every alternate leaf.

\section{Cuphea radicans. Rooting Cuphea.}

Stem herbaceous prostrate rooting near the base pubescent towards the apex, leaves elliptic subacuminate at both ends minutely hispidulous and ciliated, flowers axillary shortly pedicelled bracteolated, calycine tube hispidulous, petals 6 subequal, stamens 6 unequal.

II A B. Dolly-Mohun's Gap, St. Andrew's.

F. L. May, June.

Stem herbaceous, about six inches in length, prostrate, rooting towards the sase, sparingly branched, minutely pubescent. Leaves opposite, shortly petiolate, elliptic, subacuminate at both ends, minutely hispidulous and ciliated. Flowers solitary, axillary, shortly pedicelled, pur. ple, furnished at the base with a pair of minute bracteoles. Calycine teeth 6: tube striated, hispidulous. Petals 6, oblongo-ovate, clawed, spreading, subequal: the two upper ones more widely separated: the two lower ones subacute. Stamens 6, shorter than the tube of the calyx, unequal. Ovary compressed: style short; stigma obtuse. 


\section{Cuphea decandra. Shrubby Cuphea,}

Shrubby erect very much branched, branches towards the extremity compressed and hispidulous, leaves ovate acute at the base ciliated, flowers at the end of the branches few racemose subsecund, petals 5 (?)-6, stamens 10 .

Lythrum ciliatum, Swartz, Fl. Ind. Occ. 868.-Cuphea decandra. Hort Kew. ed. 2. III. 151.

I A B. The mountains, not uncommon.

F L. Throughout the year.

A shrub about two feet in height; branches towards the end subtet:agonal, minutely hispidulous. Lzaves opposite, very shortly petiolate, half an inch in length, with a pex bluntish, attenuated along the petiole, entire, glabrous with exception of the axils of the nerves beneath. Raceme terminal, few-flowered : flowers pink, shortly pedicelled, subsecund: pedicels hispidulous. Calyx tubular, gibbous on the upper side near the base, 12-striated, externally hispidulous: teeth 6, plicate, erect. Petals 6, oblongo-spathulate, clawed, horizontally spreading: the four lower petals subequal; the two upper ones smaller, inserted between the teeth, each on a callous spot below the edge of the calyx. Stamens, 10-11, unequal: filaments subulate, hairy: anthers oval. Ovary conical, placed on an annular glandular disk: style subulate, pubescent: stigma obtuse. On the bursting of the capsule the seeds are found attached to a columnar placenta : they are subrotund, compressed.

\section{Acisanthera.}

Calyx ventricose 5-fid. Petals 5. Stamens 10, with anthers sagittate and versatile. Capsule covered and crowned with the calyx, subrotund, 2-celled, bi-placentular, many-seeded.-DC.

Herbaceous.-Name from akıs a point, and avөnpa an anther, on account of the anthers being pointed.

\section{Acisanthera quadrata.}

Acisanthera erecta ramosa, ramulis quadratis, Browne, 
Jam. 217. t. 22. f. 1.--Rhexia A cisanthcra, Willd. II. 303.

a Melartomasea.

II A B. Pastures, St. Thomas in the Vale Vale of Lluida.

F L. Autumn.

Herbaceous, about a foot in height, erect: branches few, tetragonal. Leaves small, ovate, 3-nerved, crenated. Flowers axillary, alternate, solitary, white, peduncled. Petals 5, obovate.

\section{. ORDER LXXV. MELASTOMACEF.}

Calycine lcbes 4, 5, or 6. Petals equal in number to the segments of the calyx, arising from their base, or from the edge of a membranæform disk, adnate to the tube of the calyx ; during æstivation twisted. Stamens usually twice as many as the petals, sometimes equal to them in number: filaments during rstivation replicato-inflected, with the anthers between the tube of the calyx and the ovary; assurgent on the opening of the flower : anthers long, bilocular, generally opening by 1-2 pores at the apex, rarely bursting longitudinally. Ovary more or less concrete to the calyx : style 1: stigma simple : a cup often present on the apex of the ovary, surrounding the insertion of the style. Pericarp either dry and distinct from the calyx, or succulent and concrete with the calyx, many-celled: placentæ attached to a central column. Seeds innumerable, minute, with a brittle testa, and no albumen; embryo straight : cotyledons unequal.

Tree or shrubs, rarely herbaceous. Leaves opposite, undivided, with several strong nerves or ribs, running 
from the base to the apex. Flowers terminal, usually thyrsoid. By these characters and the long beaked anthers, the Melastomace $æ$ are readily recognized, and the different genera, of which the family is composed, can be easily distinguished. The species are almost all natives of intertropical countries, there being 620 species indigenous to the warmer regions of South America. None of the species possess any remarkable properties. They all have a slight degree of astringency. The fruit of some species is edible: that of others stains the mouth black, and hence the name Melastoma.

\section{Tribe 1. LAVOISEREA.}

Anthers 1-2-pored at the apex. Ovary free at the apex, without scales or setæ. Capsule dry. Seeds ovate or angled, not cochleate, with the hilum lateral and linear.-American plants.

\section{Meriania.}

Calycine tube campanulate, limb $5-6$ lubed, with the lobes dilitato-membranaceous at the base, subulate at the apex. Petals 5-6. Anthers obtuse at the apex opening by a double pore, furnished with a very short spurred process at the base. Ovary globose, sub-depressed at the apex, glabrous, with the placentæ lunated. Seeds minute, cuneato-angled.

Low trees or shrubs, natives of Jamaica or South America.-Name given by $\mathbf{S w a r t z}$ in honor of Maria Sybilla Merian, authoress of a work on Insects.

1. Meriania leucantha. White-Flowered Meriania.

Branchlets tetragonal compressed glabrous, leaves ovato-oblong acuminate 3 -nerved serrulated, bracteæ 2 beneath each flower ovato-lanceolate 5-nerved very entire.

Swartz, Fl. Ind. Occ. 826. 
II A B. Common, higher mountains.

F. L. June-August.

A shrub, 5-10 feet in height, erect, branched. Leaves opposite, acuminate with the apex sharp, finely serrulated, smooth shining and decp green above, paler beneath, delicately veined: petiole terete, purpurascent, channelled above. Flowers axillary, solitary, peduncled. Bracteæ leaf-like, deciduous. Calycine teeth membranaceous, expanded at the base, subulate. Petals white, tinged, with crimson near the base. Stamens 10: filaments teneiform: anthers lanceolate, incurved at the apex. Ovary 5 lobed: style slightly declinate: stigma simple. Capsule 5-valved: seeds numerous, minute, wedge-shaped.

\section{Meriania rosea. Rose Meriania.}

Branchlets terete glabrous, leaves oval 3-nerved subserrulated glabrous, biglandulose at the base, bracteæ 2 linear slightly expanded at the apex.

Tussac, Fl. Antill. 78. t. 6.

II A B. Higher mountains. Near St. Catherine's peak.

F. L. February-May.

A shrubby tree, about 16 feet in height: branchlets purpurascent. Leaves acuminate with the apex sharp, subacute at the base, 3-nerved, glabrous with exception of the under surface of the nerves where it is hispidulous, serrulated: petiole slightly grooved above, hispidulous. Peduncles axillary, solitary, one-flowered, about an inch in length, compressed. Bracter 2, an inch in length, linearicylindrical, somewhat dilated and convoluted towards the apex. Calycine divisions subulate, with a membrana. ccous expansion at the base. Petals rounded at the apex, and slightly extended on one side, of a crimson red. Stamens 10; filaments flattened, teneiform : anthers lanceo. late, white, furnished at the base with a spur-like process, previous to expansion doubled down on the filaments, springing up on evolution. Ovary globose, 5-lobuled at the summit: style cylindrical, with five lines of asperities towards the apex, erect: stigma simple. Capsule 5. celled: secds many, 


\section{Meriania purpurea. Purple Meriania.}

Branchlets terete glabrous, leaves ovato-lanceolate denticulated glabrous, bracter 4 lanceolate denticulated.

Swartz, Fl. Ind. Occ. 829.

II A B. Higher mountains.

F L. Autumn.

A shrub, 15 feet in height: branchlets purpurascent. Leaves slightly recurved at the apex, 3-nerved, of a dark grcen colour: petiole channelled above; when young, as also the nerves of the leaves, puberulous. Peduncles axillary, solitary, one-flowered, an inch or more in length. Bracteæ leaf-like, sessile, 3.nerved. Calycine lobes 5, erect, subulate, broad at the base. Petals 5, purple. Stamens 10, declinate: anthers yellow. Ovary 5, lobuled at the summit; style length of the stamens: stigma rounded. Capsule as in the preceding species.

These three species are beautiful shrubs, with showy flowers. It is to be regretted that we have not yet been successful in establishing them in our gardens. They resemble some species of the animal kingdom, which soon pine and die when removed from the wild haunts of nature, rotwithstanding every care and attention. These plants are very common in the moist damp woods of the higher mountains.

\section{Tribe II. RHEXIE.A.}

Anthers 1-pored. Ovary free at the summit, without scales or setæ. Capsule dry. Seeds cochleate, with the hilum orbiculate and basilar.

\section{Spennera.}

Calycine tube globose : lobes 4-5, short. Alabastrum conical. Petals lanceolate, acute. Stamens 8-10: anthers ovate with a long spur-like curved appendage from the base. Capsule dry, 2-3-celled: seeds echinulated.

Name, in honor of M. Spenner, a distinguished Bota. nist. 


\section{Spennera aquatica. Marsh Spennera.}

Stem branched, branches quadrangular subpilose, leaves cordate ovato-oblong acuminate serrulated 3-nerved besides the marginal pair, glabrous above, appresso-subpilose along the nerves beneath, divisions of the panicle elongated filiform lax, capsule 3-celled.

Melastoma aquatica, Aubl. Guian. 430. t. 169.-Swartz Prodr. 73.-Rhexia aquatica, Swartz. Fl. Ind. Occ. II 650.-Spennera aquatica, DC. Prod. III. 116.

H A B Wet pastures. Moneague, Dr. Alexander.

F L. Throughout the year.

Shrubby, erect, 1-3 feet in height, slightly hispid: branches tetragonal. Leaves opposite, petiolate, ovato-oblong, cordate, acuminate, 3 nerved besides the marginal pair, glabrous above, appresso-pubescent along the nerves beneath. Panicle terminal: branches filiform, purplish, loose, 3-chotomously divided: pedicels nearly an inch in length, filiform, jointed about a line from the flower, with a pair of minute bracteoles at the joint. Calyx 4rarely 5 -toothed: teeth acute. Petals 4 , rarely 5 , oblong, acute, shorter than the stamens. Stamens 8 , rarely 10 , purple. Style length of the stamens: stigma obtuse. Capsule 3-celled, subglobose : seeds numerous, minute, ovoid.

\section{Tribe III. MICONIE.E.}

Anthers 1-2-pored. Ovary adnate to the calyx. Fruit a berry. Seeds not cochleated.

\section{Clidemia.}

Calycine tube ovate, naked or rarely bibracteolated; lobes persistent, narrow, acute. Petals 5 , very rarely 6 . Stamens 10 , with the anthers constricted and sub-biauriculated at the base, one-pored at the apex. Ovary adnate to the calyx, crowned with setæ, frequently arranged in a circular manner. Style filiform. Stigma a pruinose point. Capsule berried, 5-celled. Seeds ovate or somewhat angular. 
Name in honor of Clidemi, an ancient Greek Botanist.

\section{Clidemia hirta. Hairy Clidemia.}

Branches round with the petioles and panicles hispid with rufous hairs, leaves ovato-lanceolate sub-attenuated at the base, acuminate at the apex denticulated 5-nerved, along the nerves densely, elsewhere sparingly hairy, panicles axillary 3-chotomous few-flowered scarcely the length of the petiole, teeth of the calyx ovate hairy, petals obovate, stamens 10 .

Melastoma hirta, Suartz, Obs. 175.-Sims Bot. Mag. 1971.-Clidemia hirta, DC. Piod. IlI. 157.

Il $\mathrm{A}$ B. Mountain forests.

P L. Spring and Autumn.

A shrub 3-4 feet in height: branches hairy: branchlets ferrugineo-hispid. Leaves rugnse, soft, very hairy : petiole rather long, terete, hirsute. Panicles axillary and terminal, solitary, 3-5-flowered. Hairs on the calyx tinged with crimson. Petals ovate, white, not so long as the segments of the calyx. Filaments short. Siyle thick : stigma obtuse, concave. Berry crowned with the calyx, hairy, blue, 5 -celled.

According to Swartz the flowers are sometimes dode. candrous; calycine teeth 6 : petals 6 ; berry 6 -celled.

\section{Clidemia Strigillosa. Coarse-leaved Cli- demia.}

Branches and petioles hairy, leaves oblong subcordate at the base thrice the length of the petiole acuminate 5-nerved besides an obscure marginal pair subdenticulated piloso-hispid abore canescenti-tomentose beneath, racemes axillary with the branches opposite 3-4 flowered, calyx hirsute with the tceth filiform, petals oblong.

Melastoma strigillosa. Suentz, Fl. Ind. Occ, 793,Clidemia strigillosa, DC. Prod. III, 159. 
II A B. Mountain woods.

Fl. Spring and Autumn.

A shrub: branches at the end tetragonal, and pilose, Leaves 3.4 inches long, nerved, strigose and rufous above, reticulately veined and hoary-tomentuse beneath: petiole an inch in length. Panicle axillary, solitary, erect, shorter than the leaves; fluwers $3-4$ together, purpurascent. Calycine teeth 5, long, filiform, hispid, erect. Petals oblong, shortly clawed. Filaments 10, filiform, short, kneed: anthers linear, incurved, short. Ovary hirsute; style short: stigma obtuse. Berry crowned with the calyx, hirsute, many-seeded.

\section{Clidemia hirsuta. Rough-leaved Clidemia.}

Branches subterete, as also the petioles, upper surface of leaves and peduncles hispid with short thick strigose setæ, leaves ovate acuminate 3-plynerved serrulateù rugose above reticulato-foveolated beneath, thyrse terininal short sessile, divisions '2-flowered, calycine tceth 5 reflected, petals lanceolate, stamens 10.

II A B. Port Royal Mountains, near Rosanna Mount. F L. June.

A shrub 4-6 feet in height: branches patulous, compressed at the end, strigoso-scabrous with dense short subulate hairs. Leaves opposite, petiolated, ovate, acuminate, unequal at the base, denticulato-scrrulated, 3-plynerved, with the lateral nerves not opposite, and a marginal pair indistinct, deep green above, paler beneath, with the nerves ferruginous: petiole strigosn-hirsute. Panicle terminal, scarcely the length of the leaf, trichotomously divided: branches opposite, spreading horizontally, strigoso-hirsute, coloured; central division bearing two shortly pedicelled obscure flowers. Calycine teeth subulate: tube campanulate, with a line of minute hairs in the throat. Petals twice the length of the calycine teeth, lanceolate, with a toothlet on one side near the insertion, tinged with rose colour, reflected. Stamens 10: anthers yellow, nne-pored. Style Innger than the stimons, thick, acuminate: stigma obtusc. Berry size of 
a coriander seed, b!ack, purple, 5 -celled: seeds minute, wedge-shaped, whitish, numerous.

This approaches very closely to the Cuidemia Lima of DeCandolle, a native of the Caribean Islands.

\section{Calycogonium.}

Calycine tube subglobose 4-5-sided with the angles acute and continuous with the mid-rib of the lobes, subaccrete: lobes $\mathbf{4}-\mathbf{5}$, spreading, oblongo-linear, longer than the tube. Petals 4-5, obovate. Stamens 8-10, equal: anthers oblong, l-pored. Stigma punctiform, Berry subrotund, angular, crowned with the lobes of the calyx, 4-5-celled. Seeds ovato-angular, with a linearhilum.-DC.

Name from $\kappa a \lambda \nu$ the calyx, and ywra an angle.

\section{Calycogonium glabratum. Glabrous Caly- cogonium.}

Branches subterete glabrous, leaves elliptico. lanceolate attenuated at the base sub-entire obscurely triply-nerved subcoriaceous, peduncles terminal shorter than the petiole subsolitary 1flowered, calycine lobes subulate.

Melastoma glabra, Swartz, Fl. Ind. Occ. 806.-Prod. ejusd. 71.-Calycogonium glabratum, DC. Prod. III. 168.

II A B. Salt-Hill Pastures, and Halberstadt; Port-Royal Mountuins.

F L. August. Towards the end of the year, Swartz.

A shrub about six feet in height: branches erect, stiff, glabrous, ash-coloured, compressed at the end. Leaves an inch and a half in length, and three-fourths of an inch in breadth, opposite, shortly petiolate, elliptico-oblong with the apex bluntish, attenuated at the base, subentire, glabrous, punctulated beneath, apparently nerveless on the upper surfuce, 3-plynerved, on the under, with an oval brown membranaccous excavated glandule in the 
angle of each nerve. Flowers white: pedunchs short, solitary, seldom more thun one-fluwered. A pair of minute ovate bracteoles appressed to the calyx. Calyx more or less tinged with crimsun; extemally with a mit nute stellated pubescence; globose at the base: tube subtetragonal; tceth 4 , long, subulate, inserted below and outside of the margin which is subentire. Petals shor ter than the calycine teeth, spathulate with the apex acute. Stamens 8: filaments kneed: anthers curved, lanceolate, one-pored, yellow. Ovary glabrous: style subulate, longer than the stamens, stained with crinison: stigma acute. Berry crowned with the tube and tweth of the calyx, black, 4-celled: seeds numcrous, wedgc-shaped, angular.

According to Swartz, the leaves are 3-nerved. This error has been corrected by DeCandolle, who has properly described them as 3-ply-nerved; but adds, that the margin is subrepando-denticulated--a character which I have not observed in the specimens that I have met with. The leaves, in this species, are less distinctly nerved than in any other of the order.

\section{OSSAeA.}

Calycine tube adherent to but not produced beyond the ovary, ovate; lobes 4 , short, acute. Petals 4, lanceolate, acute. Stamens 8, short: anthers scarcely auriculated at the base. Ovary subglabrous at the apex : style filiform : stigma simple. Berry 4 -celled, crowned with the lobes of the calyx : seeds ovate, angular.

Leaves generally triply-nerved. Flowers small, axillary. - Named by DeCandolle in honor of Senor de la Ossa, a Botanical explorer of Cuba.

\section{Ossæa Scabrosa. Scabrous Ossca.}

Stem shrubby hirsute, branches terete hirsute, leaves ovate subacuminate denticulato-ciliated triply-nerved papilloso-scabrous foveolated and hoary tomentuse beneath, flowers very crowded sessile octandrous, calyx 4-cleft hirsute with divisions subulate minute, petals 4 scarcely 
longer than the calycine lobes lanceolate acute white, flaments kneed, stigma blunt, berry minute subrotund 4-celled rufous.

Melastoma subhirsuta, foliis cordatis, scabris, minutissime denticulatis, Browne, t. 24. f. 3.-Melastoma scabrosa, Sievartz, Obs. 174.-Ussæa scabrosa, DC. Prod. III. 169. Bath.

II A B. The Mountains, on wet banks. Sulphur river,

F L. November, December.

Stem $\mathbf{4 . 5}$ feet in height: branches ferruginous. Leaves rather large, triply-nerved with a marginal pair: petioles long, round, thick, hirsute. Flowers principally in the situation of the axillæ of the leaves which have dropt off; 6-10, rather obscure, sessile. Petals acute, bisetose at the apex, tinged with purple. Filaments longer than the petals. Style thick, erect, crimson : stigma simple. Berry minute, spherical, crowned with the calyx, hairy, 4 celled.

\section{Ossaea pratensis. Meadow Ossra.}

Stem shrubby hirsute, branches terete as also the petioles ferrugineo-tomentose, leaves ovate obtuse entire 3-ply-nerved rugose tomentoso-hirsute, peduncles in threes axillary each one-flowered filiform pilose, calyx tomentose with 4 subulate teeth, petals 4 ovato-lanceolate, stamens 10, berry blackish purple hairy 4-celled.

II A B. Pastures of Shenton and Tulloch, St. Thomas in the Vale.

F L. End of the year.

Stem shrubby, 2-3 feet high : branches opposite, spreading, subdistichal, terete, ferrugineo-tomentose. Leaves opposite, shortly petiolate, ovate, obtuse, entir e, rugulose, tomentoso-hirsute : petiole tomentose. Flowers axillary, peduncled: peduncles 3 together ; each one-flowered, filiform, pilose : the middle peduncle short; the lateral ones an inch in length. Calyx externally piloso-tomentose. Petals white, acute, caducous. Anthers yellow, style erect, elub-shaped: stigma simple. Berry size of a black currant, purple, hairy. 
rugineous and glabrous, leaves oblong subcordate acute at the apex with the margin subrevolute very entire 3-nerved glabrous above scurfy with a minute pubescence beneath, thyrse terminal, panicled many-flowered.

Melastoma tetrandra, Swartz, Fl. Ind. Occ. 795-M. tetrandrum, Spreng. Syst. II. 305.--Tetrazygia tetrandra DC. Prod. III. 172 .

II A B. Summit of the Blue Mountain range.

F L. May.

A shrubby tree about 12 feet in height, with spreading branches. Leaves $\mathbf{3 - 4}$ inches in length, subcoriaceous: petioles long. Thyrse terminal: divisions ferrugineofarinose: flowers small, white, crowded, subsessile. Calyx minute, 4-teethed. Petals 4, very small, ovate, concave, deciduous. Filaments 4, erect, about the length of the petais. Ovary glabrous: style subulate: stigma acute. Berry small.

\section{Tetrazygia Fadyeni.}

Branches compressed purpurascent glabrous, leaves oval (in some specimens approaching to lanceolate) entire and slightly revolute at the margin 3-ply-nerved glabrous, paler and minutely punctulated beneath, panicle cymose terminal longer than the leaves, calyx urceolate edentulous, petals 4 oblong, stamens 8, ovary 2-celled.

Hooker, Bot. Journal, for December, 1849.

II A B. Road from Lluida's to St. Thomas in the Vale, -Mount Diablo, Dr. M'Nab.--Rocks in the Pedro district, St. Ann's, $\mathrm{Mr}$. Purdie.-Albion Pen, and Friendship, St. Ann's, Dr. Alexander.

F L. July.

A shrub about 6 feet in height, branching from the root ; branches opposite, decussating, compressed towards the end and purpurascent. Leaves opposite, petiolate, elliptic, in some plants approaching to lanceolate, in others broad oval, obtuse, sub-entire with the margin slightly revolute, 3-ply-nerved with a pair of obscure

Vox. 2. 
marginal nerves, glabrous, dark green above, paler and minutely punctulated beneath, about 2 inches long, and fom an inch to an inch and a half broad. Panicle terminal, cymos?, branched. Flowers crimson, or, in the plants with broad leaves, purple; pedicels about 3 lines in length, jointed and bibracteolated near the flower. Calyx turbinate, truncated, obscurely 4-toothed. Petals oblong, rounded at the apex, half an inch in length. Stamens 8, twice the length of the petals: filaments capillary, twice the length of the anthers: anthers yellow, linear, one-pored at the apex, free of any appendage. Ovary 2-celled: style length of the stamens: stigma obtuse. Fruit size of a small pea, a dry capsule, 2. celled : seeds numerous, minute; wedge-shaped, angular, with a longitudinal hilum.

In reference to this species, Sir William Hooker wrote as follows : - "Your Melastomaceous plant is, as a species, quite new, but will sufficiently accord with the Genus Tetrazygia. It is remarkable for the long sta. mens, erect red or purple petals, and 2-celled ovary. I call it Tetrazygia Fadyeni. I had it from you long ago. I hope you will not object to the specific name."-This is a beautiful plant, and has been introduced into gardens as a flowering shrub.

\section{Tetrazygia ecostata. Plane-leaved Tetra- zygia.}

Leaves ovato-lanceolate acuminate denticulated ecostate triply-nerved pilose above subglabrous beneath, corymb terminal 3-chotomous, branchlets peduncles aud calyces pulvereo-tomentose, flowers octandrous.-DC:

Ait. Hort. Kew. II. 46.

II A B Jamaica.

FL. ?

4. Tetrazygia hispida.? Purple-flowered Tetrazygia.

Branches terete glabrous, branchlets hoary, leaves ovate acuminate obsoletely denticulated 
5-nerved, strigoso-hirsute above, reticulated and tomentose beneath, panicles terminal, flowers oclandrous, calycine teeth 4, petals 4 oblong with the margin undulated purple, anthers acuminate, berry-?

Melastoma hispidum, Swartz, Fl. Ind. Occ. 831.

II A B. Mountains.

F L. —?

A shrub. Leaves without a pair of marginal nerves, somewhat thick: petioles hirsute. Branches of the panicle loose. Flowers rather large, purple. Teeth of the calyx short, erect, hairy. Filaments 8, short : anthers acuminate. Ovary strigose! style ascending, incrassated: stigma acuminate.

This species has been seen only by Swartz. The des. cription is very imperfect.

\section{Tetrazygia discolor. Discoloured-leaved Tetrazygia.}

Branches petioles panicles and under surface of the young leaves white with a short sub-floccose stellated pubescence, leaves ovali-acuminate 5-nerved glabrous on the upper surface repandosubdenticulated, cyme terminal paniculato-corymbose 3 -chotomous, calycine teeth 4 short obtuse, petals oval obtuse.

Arbor Americana quinquenervia, foliis amplissimis prona parte albicantibus. Pluk. Alm. t. 264. f. 4.Grossulariæ fructu non spinoso malabathri foliis subtus niveis. Sloane, Hist. II. p. 86. t. 198. t. 1.-Melastoma discolor, Swartz, Obs. 178.-Jacq. Amer. 130. t. 84.

II A B. Road to Guanaboa. Sloane.

I L. L?

According to Jacquin the flowers are small. Calyx subrotund where it is adnate to the ovary ; contracted at the throat; with the limb quadrangulari-campanulate, 4 toothed. Petals yellow, oblong, truncated. Stamens 8 , declinate. Berry crowned with the calyx, 4-celled seeds numerous, minute, with the juice purple. The shape of the calyx resembles that ascribed to HARRERA. 


\section{Tetrazygia angustifolia. Narrow-leaved Tetrazygia.}

Branches terete with the petioles and under surface of the leaves most minutely stellato-pubescent, leaves lineari-lanceolate with the margin revolute very entire flavo-punctulated above 3-neived with the lateral nerves close to the margin, cymes paniculato-corymbose terminal, limb of the sub-globose calyx 4-toothed-DC.

Melastoma angustifolia, Swartz, Fl. Ind. Occ. 770.

II A B. - ?

F. $L$,

Leaves 1.2 inches in length, rugose and glabrous above, hoary beneath. Flowers pedicelled, crowded, small, lutescent Petals subrotund.-Swarlz. According to other Botanists, the petals are obovate, and white with a rose-tinge. $-D C$.

\section{Harrera.}

Calyx where it adheres to the ovary globular: tube contracted and produced; limb expanded, 5-rarely 4-toothed with the tieth inserted below the margin Petals 5, rarely 4, rounded. Stamens 8-i0, declinate: anthers onepored, sub-auriculated at the base. Ovary umbilicated. Capsule berried, 3-6-celled: seeds wedge-shaped.

I am unwilling to institute a new genus: but the plants comprehended under this head do not appzar to me to be. referable to any of those already established. From the fruit, with the calyx, resembling in shape the Spanish jar, so commonly used by us to keep water cool, I have derived the generic designation from the Spanish Jarrero, which mearis a maker of Jurs. I may add that in Spanish, $\boldsymbol{J}$ has a gutteral sound like that of $\boldsymbol{H}$, strungly asperated. I have therefore, in Latinizing the original word, substituted the latter, for the former ietter. 


\section{Harrera gerascanthoides. Shovy Har- rera.}

Arborescent, branchlets slightly compressed furfuraceo-tomentose wi'h minute stellated hairs, leaves elliptico-lanceolate attenuato-acuminate 3-nerved sub-entire, glabrous above, minutely stellato-tomentose and paler beneath, panicle cymose terminal, stamens 10 , berry 3 -celled.

H A B. Port Royal Mountains. Salt Hill.-Near Dove Hall, $D r$. Alexunder.

F L. September.

A tree nearly 20 feet in height: branches sprearing, terete, ash-coloured, towards the extremity minute!y firlfuraceo-tomentose. Leaves opposite, sometimes alternate, petiolate, ovato-lanceslate, attenuato-acuminate, rounded at the base, entire, 3 -nerved besides an obscure marginal pair, glabrous and green above, albidostellato-tomentulose and farinose beneath, $3 \frac{1}{2}$ to $4 \frac{1}{2}$ inches in length, and an inch and a half in breadth: petiole terete, nearly an inch in length. Racemes cymose, terminal, erect: peduncle compressed, tetragonal, minutely stellato-puberulous : divisions opposite, decussating. Flowers large, white, showy, shortly pedicelled. Calyx externally stellato-puberulous: tube produced, funnelshaped; limb spreading, with $\mathbf{5 \cdot 4}$ indistinct and blunt green teeth placed on the outside; throat furnished with a membrane, on which the petals and stamens are inserted, forming as it were a pentangular disk with the centre open. Petals 5, rarely 4, somewhat contorted, obovate, rounded at the apex. Stamens 10, declinate in a diraction opposite to that of the style : anthers lanceolate, acute, one-pored, slightly auriculated at the base. Ovary umbilicated: style tinged with crimson, longer than the stamens, declinate and somewhat curved. Berry size of a large pea, black, crowned with the calyx, 3-celled; seeds wedge-shaped, angular, marked with a crimson line (the hilum) on one side.

The flowers of this species bearing some resemblance at a distance to those of the Spanish Elm, cordia GERAScanthordes, has induced to apply to this its specific designation. As in it, the corolla is marescent; and the 
stamens and style deciduous. The flowers have a beautiful appearance, even on close inspection, from the pure white of the corolla, the golden yellow of the anthers and the crimsnn of the style. Dr. Alexander has suggested the resemblance of this plant to tetrazygia ELAEAGINOIDES.

\section{Harrera sparsifolia. Scattered-leaved Har- rera.}

Branch s compressed somewhat sulcated ferrugineo-tomentose, leaves scattered and crowded at the ends of the branches ovale sub-cordate denticulated 5-nerved glabrous above. ferrugineo-tomentose beneath, thyrse terminal, flowers subsessile, calycine teeth $4 \cdot 5$, stamens 8 .

H A B. Near Guav?-ridge.

F L. August.

A shrub 10 feet in height: branches erect, compressed, somewhit sulcaled, ferrugineo tomentose. Leaves scattered, rather crowded at the ends of the branches, ovate, subcordate, acuminate, with the apex somewhat retuse, and the margin revolute and minuiely and distantly den. ticulated, 5-nerved besides a marginal pair, glabrous above, hoary and ferrugineo-tomentose beneath: petiole subtrigonal. 'Thyrse terminal: peduncle compressed, subtetragonal, hoiry and ferrugineo-1mmentose : branches decussat.ng, bearing three or more subsessile white flowers. Calyx 8-10-agonal, in shape like a Spanish Jar: at the hase glubular: throat produced and contracted: limb expanded, internally purple. marked in the centre with a radiating disk, with the rays 4.5 of a pale colour, the angles alternating with the divisions of the calyx : teeth $\mathbf{4 - 5}$, short, subulate, inserted externally below the margin. Petals 4, rarely 5. obovate, clawed, rounded at the apex. Stamens 8, rarely 10, declinate: anthers auricu'ated at the base, one-pured. Style declinate, curved: stigma simple. Berry globose, 6-(?) celled.: seeds ovoldeoreniform.

The mark on the ins:de of the calyx, resembles that observable in HETEROTRICHOM PATENS. I have met with only one plant of this species. The arrangement of the 
leaves is very remarkable, and for a time puzzled me much. Were it not for several discrepancies, it might be referred to the succeeding Genus.

\section{Harrera trinervis. Three-nerved Harrera.}

A shrub, branches at the end compressed and slightly sulcated, as also the under surface of the leaves the peduncles and petioles albido-rufescent and stellato-tomentulose, 1 -aves ovato-lanceolate rounded at the base sub-entire, calyx globose where it adheres to the ovary 4 -toothed, stamens 8, berry 3-celled.

H A B. Near Green Valley, Port Royal.

F L. August.

A shrub 5.10 feet in height; branches erect, com. pressed, towards the extremity slightly sulcated on the flattened sides, and minutely and densely stellato-puberulous. Leaves opposite, petiolate, ovato-lanceolate, acuminate, rounded at the base, sub entire, 3 -nerved beside the marginal pair, above apparent!y glabrous, $r$ ut to the glass minutely stellato puberulous, beneath incano-ferruginous, and farinoso-tomentulose with a minute stellated pub. escence: petiole stellato-tomentulose. Panicle terminal of comparatively few flowers, shorter than the leaves: branches decussating. Flowers white, shortly pedicelled. Calyx globose whe e it covers the ovary: the tube 8 agonal, stellato-puberulous: limb spreadiı,g, with 4 subulate teeth inserted below the edge of the limb. Petals 4. Stamens 8: filaments kneed: anthers yellow, 1pored. Style longer than the petals; stigma simple. Berry purple, 3-celled: seeds wedge-shaped.

\section{Heterotrichum.}

Calycine tube ovato-globose; limb 5-8-fid, with the lobes subulate, elongated, persistent, broadly dilated at the base. Petals 5- $₹$, oval. Stamens 10-16, equal: filaments glabrous; anthers oblong scarcely gibbous, bi-porose at the apex. Ovary glabrous at the apex, umbilicated: style cylin- 
drical: stigma a pruinose point. Capsule berried, 5-8-celled, globular, crowned with the calyx.

Name from हrøgos diverse and rgtx s hairs; referring to a peculiarity in the plants of this Genus: there being two descriptions of hairs, viz, a stellated pubescence intermixed with rigid stiff setæ.

\section{Heterotrichum patens. American Goose- berry.}

Branches petioles peduncles and calyces hirsute with glandulose setæe, intermixed with a minute subvelutine stellated pubescence, leaves cordate acuminate subdenticulated 7-nerved, scabrous above, albido-velutine beneath, cyme terminal lax, flowers 6-8-fid, calycine lobes patent.

Melastoma patens-Swartz, Fl. Ind. Occ. 791.-Heterotrichum patens-DC. Prod. III. 173.

II $A \mathrm{~B}$. Common in the mountains.

F $L$. Throughout the year.

A shrub, 6-8 feet in height: branches spreading, purpureo-erubescent on the upper side. Leaves 4-5 inches in length, on a long petiole, 5 -nerved besides the marginal pair, reticulato-venose, deep green and hispid with long capitate hairs, intermixed with a stellated pubescence on the upper surface, albido-tomentose with a ferruginous tinge on the under: petiole 23 inches long. Cyme terminal, shorter than the leaves, erest; branches compressed, incano-tomentose, patulous, pedicels three-fourths of an inch in length, jointed and bibracteolated near the flower. Flowers rather few, large. Calyx usually 6 fid: lobes rounded, each bearing on the back an elongated subulate apicula; throat marked with a hexangular disk of a fawn colour, with the angles alternating with the lobes of the calyx. Petals usually 6, obovate, obtuse, veined, patent. Stamens 12, declinate; filaments crimson: anthers yellow. Style declinate, longer than the stamens: stigma excavated. Berry size of a large black currant, black, shining when ripe, hirsute with capitate hairs with a mi- 
pored. Ovary ovato-oblong, crowned with a thick glabrous callous disk. Stigma peltate or capitate. Capsule dry, indehiscent, 5-celled: seeds ovate.

Name from $\delta i \pi \lambda_{0 o s}$ double, and $\chi^{i \tau \omega \nu}$ a coat of mail, or covering; in allusion to the pair of bıacteoles wrapped around the young flower.

\section{Diplochita Swartziana. Swartz's Diplo- chita.}

Branches subterete, as also the petioles peduncles and under surface of the leaves furnished with a minute stellated incano-rufescent pubescence, leaves oblongo-elliptic acuminate 5-nerved entire, thyrse strict, bracteæ deciduous, calyx externally stellato-pruinose, petals $5-€$, stamens 10-14.

Grossulariæ fructu arbor maxima non spinoso, fructu majori. Sloane, II. 84.-Melastoma Tamonea, Swartz, $\boldsymbol{F l}$. Ind. Occ. 783-M. Swartziana, Richard in Bonpl. Mel. t. 33.-Diplochita Swartziana, DC. Prod. III. $17 \%$.

H A B. Port Royal and St. Andrew's Mountains.

F L. January, February.

A tree-like shrub, 15-20 feet in height: branches spreading. Leaves attenuato-acuminate, 5 -nerved besides a marginal pair, dark green and glabrous above, rufescent and stellato-pubescent and farinose beneath, $\mathbf{3 . 4}$ inches long: petiole rather long. Thyrse a foot in length. Flowers showy, pedicelled, in threes. Bracteæ 2, so large as to cover up the flower previous to opening, broad-oval, longitudinally nerved, pruinose with a minute stellated pubescence, deciduous. 'I'here are also minute ovate deciduous bracteæ in pairs at the division into the three pedicels. Calyx urceolate, externally stellato pruinose: limb 5-6-dentate with the teeth blunt: throat with a circle of 10-12-14 tufis of silky pubescence, marking the interstices between the points of insertion of the filaments. Petals 5-6.oblong, white, delicately veined with crimson.

VoL. 2. 
Stamens 10-14 : filaments curved, crimson : anthers bright yellow. Ovary free, elongated, marked with 12 minute lines of pubescence: style thick, declinate: stigma depressed. Berry spherical, dry, 5-6-celled; seeds ovate, obtuse; hilum black.

\section{Diplochita rosea. Rose Diplochita.}

Branches tetragonal, together with the petioles peduncles and under surface of the leaves ferrugineo-tomentose, leaves oblongo-lanceolate acuminate 3-nerved entire, thyrse terminal, bracteæ obovate rounded at the apex deciduous, calyx externally tomentose, petals 5, stamens 10 .

II A B. Banks of the Rio-Grande.

F L. January.

An arborescent shrub. Leaves opposite, decussating, 3-nerved with a marginal pair, glabrous above, tomentose and paler with a ferruginous tinge beneath: petiole an inch and $a$ half in leng'h. Panicle terminal; divisions brachiate, with the terminal subdivision 3-flowered. Bracteæ 2, inclosing the flower, obovate, rounded, concave, 3-nerved, incano-tomentose, deciduous. Calycine lobes 5, obtuse, externally tomentose. Petals 5, scarlet, veined. Filaments yellow: anthers arcuate, thick to. wards the base. Fruit?

\section{Diplochita Fothergilla. Fothergill's Di- plochita.}

Branchlets subrotund, when young compressed and ferrugineo-velutine, leaves oval acuminate rounded at the base subentire 5-nerved glabrous above albido-velutine with a stellated pubescence beneath, thyrse panicled, branches of the peduncle tetragonal and sulcated velutine, bracteæ and . calyx albido-velutine with minute stellated hairs, stigma dilated subpeltate.

Fothergilla mirabilis, Aubl. Guian. İ. 441. t. 175Melastoma Fothergilla, Rich. in Bonpl Mel, t. 32-Dipluvhita Fothergilla ; DC. Prod. III. 176, 
If A B. Mount Diablo. Dr. Alexander.

F L. May.

A beautiful tree, with the stem straight andsimple, about 25 feet in height, branches spreading. Leaves petiolate, about 5 inches long and 2 broad, slightly denticulated towards the apex. Calyx 5-toothed. Petals twice the length of the calyx, oblong. Anthers yellow.

\section{XiI. Henriettea.}

Calyx campanulate; lobes 5 , broad, obtuse. Petals 5, velvetty, ovate. Stamens 10: anthers thick, bifid at the base, with a long beak at the apex, one-pored. Style cylindrical, hairy. Stigma capitate, obtuse. Berry juicy, 5-celled : seeds cuneato-ovoid.

\section{Henriettea ramiflora. Common Henriettea.}

Branches towards the end compressed and ferrugineo-hispidulo-tomentose, leaves elliptico-lanceolate acuminate at both ends entire 3-plynerved besides the marginal pair strigoso-hispidulous especially along the nerves ciliated, peduncles from the axils of the old leaves 10-15 crowded one-flowered, calyx urceolate obtusely 5-lobed, petals ovate.

Melastoma ramiflora, Swartz, Fl. Ind. Occ. 775-Henriettea ramiflora, $D C$. Prod. III. 178.

H A B. In damp thickets, St. Thomas in the Vale. Moneague, $D r$. Alexander.

F L. January.

A tree-like shrub. Leaves at the ends of the branches, shortly petiolate, about 5 inches long and 2 broad, bright green above, paler with a rufescent tinge beneath. Peduncles of equal length. about one third of an inch, filiform, one-flowered. Alibastrum conical. Calyx obtusely 5-lobed. Petals 5, oblong, reflected. Stamens 10, erect. longer than the petals: filaments capillary : anthers 1 . pored. Style incrassated towards the stigma which is 
obtuse. Berry size of a black pepper, 4-celled; seeds numerous, elongato-ovoid.

\section{Henriettea grandifolia Large leaved Henrietlea.}

Branches tetragonal sulcated, towards the end ferrugineo-tomentose and farinose, leaves subsessile oval subacuminate spathulate and attenuated at the base entire 3-ply-nerved besides the marginal pair subglabrous above, ferrugineo-farinose especially along the nerves beneath, flowers in the axils of the old leaves pedicelled in clusters.

Arbor maxima, foliis a concursu nervorum ima parte longius productis, subtus lanugine candicante tomentosis, Pluk. Alm. 50. t. 249. f. 2.-Mielastoma foliis amplioribus per petiolum recurrentibus et contractis, fasciculis florum sparsis, Browne, 219. t. 29. f. 1. 2.-M. sessilifolia, Willd. Sp. Pl. II. 584.

H A B. St, Mary's Woods, Dr. MacNab.

F L.

Leaves about 10 inches long, and 6 broad, situated towards the extremity of the branches. Pedicels $\frac{1}{2}$ an inch in length, one-flowered, clustered in the axils of the leaves of a former year. Calyx obtusely 5-lobed, afterwards subentire. Berry size of a black pepper, 5-celled : seeds numerous, dry, very minute, wedge-shaped, with a brown linear hilum.

\section{Henriettea. racemosa. Racemed Henri- ettea.}

Branches subtetragonal glabrous, leaves lanceolate entire 3 -ply-nerved besides a marginal pair glabrous, racemes in the axils of the old leaves or lateral.

H A B. Wood-Side, St. Mrary's, -Dr. MucTab.

F L. February.

Branches leafy at the end. Leaves about 6 inches long: petiole an inch in length. Racemes one or more 
together, rather more than an inch in length: flowers small, shortly pedice!led; pedicels capillary, jointed and bibracteolated near the flower. Calyx obscurely 5-lobed. Petals 5, obtuse. Style elongated: stigma obtuse.

\section{Miconia.}

Calycine tube adhering to the ovary: limb short, persistent, 5 -toothed, with the teeth obtuse, augmented on the inner surface with a broad membrane, frequently after expansion adpressoconnivent over the ovary. Petals 5, obovate, obtuse. Stamens 10: anthers oblongolinear, shortly and obtusely auriculated at the base. Ovary somewhat umbilicated and very glabrous at the apex: style filiform: stigma obtuse. Capsule berried, 3 -celled : seeds 3 -sided, with a black linear hilum. $-D C$.

Named in honor of D. Micon, M. D., a Spanish Botanist.

\section{SECT. 1. LEIOSPHERA.}

Calyx and fruit very glahrous. Flowers crowded and uniserial along the branches of a terminal thyrse. Leaves 3-nerved, usually ciliated.

\section{Miconia circumsecta. Sessile-flowered Miconia.}

Branches tetragonal as also the panicles and petioles glabrous, leaves lanceolate attenuated at the apex minutely ciliato-serrulated 5-nerved with the lateral pair less distinct glabrous with exception of a nidiform tuft of brown hairs in the axils of the central nerves on the under surface, branches of the thyrse filiform bifurcating, flowers small, calyx minutely 5toothed, with the tube after flowering cir- 
cumcised, stamens 10 , stigma umbilicated, berry 5-celled.

II A B. Near the Moneague.-Dr. Alexander.

F L. January-March.

A shrub, about 12 feet in height. Leaves about 8 inches in leligth, rounded at the base, attenuated at the apex, finely serrated with the teeth setose, 5 -nerved besides a very obscure marginal pair, with the nerves on the under surface coloured; tufts of woolly hairs copious, and of a brown colour. Thyrse terminal, rather shorter than the leaves; branches opposite, bifurcating, with the subdivisions long, filiform, bearing the small sessile flowers in a spike-like manner. Alibastrum globose: calyx glabrous, urseolate: teeth 5 , minute; the tubular portion circumcised as the fruit ripens; tube furnished internally with a circular projecting membrane for the insertion of the petals and stamens. Petals 5, rounded, concave, white. Stamens 10, purple: anthers oblong, opening by a single pore. Style erect, rather short. Berry size of a black pepper, juicy, blackish, 5-celled: seeds minute.

This species comes very near to Miconia congestrFLORA, a native of the Brazils.

\section{Miconia verticillata. Scarlet-berried Mi- conia.}

Branchlets bisulcated sub-hexangular, leaves very shortly petiolate opposite unequal in size lanceolate entire 3-nerved without a marginal pair glabrous, inflorescence terminal an interrupted spike with the flowers sessile crowded whorled, berry 5-celled.

II A B. Damp wooded gullies-Near Moneague,, $\mathrm{Dr}$. Alexander.

F L. December-January.

A shrub about 8 feet in height: branchlets sub-hexangular, from thin sharp ridges passing down from each petiole : when young farinoso-puberulous, afterwards glabrous. Leaves, the larger ones 8 , the shorter 5 inches in length, thin, membranaceous, glabrous, entire: petiole 
one-third of an inch in length. Spike about 6 inches in length. Flowers very minute. Calyx obscurely 5toothed. Ovary umbilicated, with the umbilicus sheathing for the reception of the base of style, with the margin of the sheath minutely ciliated. Berry scarlet, size of a coriander, 5-celled : seeds minute, ov oid.

3. Miconia serrulata. Finely-serrated Miconia.

Glabrous, branchlets tetragonal slightly sulcated, leaves oblongo-lanceolate rounded at the base obtuse at the apex sharply serrulated with the teeth setose 3-nerved besides the marginal pair, panicle terminal, branchlets short subdivided with the flowers subsessile and clustered.

II A B. Guy's Hill. Dr. MacNab.

F L.

Leaves 6.8 inches long and 2 broad: petiole upwards of an inch in length. Peduncle tetragonal, glabrous, with its branches subsimple. Calyx minutely 5 -toothed. Petals 5 , oblong. Stamens 10: anthers one-pored.

\section{SECT. II. ERIOSPH.ERA.}

Alibastrum globose, tomentose. Calycine tube subglobose, with the limb very short. Leaves discoloured on the under surface. Panicles terminal: flowers sessile secund cruwded at the apices of the branchlets, or along a simple rachis.

\section{Miconia holosericea. Woolly Miconia.}

Branches at the end compressed subtetragonal incano-rufescent, leaves oblong abruptly acuminate rounded and subcordate at the base obscurely denticulated 3-nerved besides the marginal pair, bright green and shining above, 
incano-rufescent and woolly beneath, flowers sessile unilateral.

Melastomu albicans, Swartz, Fl. Ind. Occ. 786-M. holosericea, Linn. Sp. 556-Miconia holosericea, DC. Prod. III. 181.

HA B. St. Thomas in the Vale.

F. L. February.

Stem 10-12 feet in height: branches free of hairiness. Leaves $4 \frac{1}{2}-5$ inches long, and about 2 broad; the urder surface of the nerves rufescent: petiole about half an inch in length. Thyrse terminal, longer than the leaves: branches patulous; branchlets bifurcated, with the subdivisions a out an inch in length, somewhat recurved. Peduncle and its subdivisions subtetragonal, incanorufescent : branchlets aureo-rufescent, subglabrous, furnished at the subdivisions with a pair of oblong rufescent arpressed bracteæ. Flowers numerous, crowded, sessile, sccund, white. Calyx externaily tomentose and rufescent, 5-dentate with the teeth small, Petals oblong, rounded at the apex, reflected. Stamens 10: anthers biauriculated at the base, one-pored. Style declinate, thick towards the stigma which is umbilicated. Berry small, subrotund, 3-4-celled, violaceous: seeds cuneato. trihedrcus,

5. Miconia rufescens. Rufescent Miconia.

Branchlets compressed rufescent, leaves broadovate shortly acuminate rounded and subcordate at the base denticulated 5-nerved sub-glabrous above incano-tomentose and rufescent especially along the nerves beneath, panicle erect length of the leaves with the branches short, flowers subsessile, calyx obscurely 5-toothed with the teeth obtuse, ovary free and produced at the apex, style elongated and minutely hispidulous.

H A B. Limestone districts, in thickets. Near Moneague, $\mathrm{Dr}$. Alexander.

F L. December-March. 
A shrub about 8 fect in height: branches ferrugineotomentose, with a red tingc. Leaves about 4 inches long, and rather more than 2 broad. glabrous above, incanotomentose and rufescent along the nerves bencath: petiole about an inch in length. Thyrse terminal, rather longer than the leaves: branches short, subdivided with a sessile flower at the bifurcation; the other flowers partly sessile and partly subsessile. Peduncle and its subdivisions rufesccnti-tomentose. Bracteoles minuts, deciduous. Calyx incano-tomentulose, globose where it covers the ovary to which it is only partially adnate : teeth 5, obscure, obtuse : throat furnished internally with a projecting ledge for the insertion of the petals and stamens. Petals 5, obtuse, externally incano-tomentulose and ciliated, reflected. Stamens 10, purpie: filaments, tæniaform : anthers one pored. Ovary umbilicated: style minutely hispidulous with the hairs directed forwards, erect, elongated: stigma depressed. Berry dry, 4celled? seeds minute, angular.

\section{Miconia elata. Large leaved Miconia.}

Branchlets angulato-sulcated ferrugineo-tomentose, leaves oblong acute serrulato-denticulated 5-nerved glabrous and of a dull green above ferrugineo-tomentose beneash, flowers decandrous, calyx subcampanulate minutely 5-toothed, stigma incrassated depressed, berry minute.

Melastoma, elata, Swartz, Fl. Ind. Occ. 781.-Miconia elata, DC. Prod. III. 182.

II A B. High Mountains.

F L. — ?

A tree, 30-40 feet in height. Leaves $\frac{1}{2}-1$ foot in length, coriaceous : petiole an inch in length. Flowers small, white, crowded, sessile._Swartz.

\section{Miconia argentea. Silvery leaved Miconia.}

Branchlets compressed decidedly 4 -sided and sulcated rufescenti-farinose, leaves elliptic acute

Voc. 2. 
at the base, shortly acuminate at the apex, dentate with the teeth irregular and blunt, 5-nerved beside the marginal pair, bright green and glabrous above, albido-velutine beneath, panicle terminal, flowers numerous shortly pedicelled, calyx acutely 5 -toothed.

Acinodendrum Americanum, 5 nervium concantibus flosculis, foliis amplissimis glabris, procera parte albicantibus. Pluk. Mant. 4.-Grossulariæ fructu arbor, maxima, non spinosa, malabathri folio maxima inodoro. Sloane, II. 84 t. 196.-Melastoma argentea, Swartz, Fl. Ind. Ovc. 779.-Miconia argentea, DC. Prod. III. 182.

II A B. Portland Woods. Iiev. T. Wharton.

F L. June.

A tall shrub. Leaves about 18 inches long and 10 inches broad: petiole about 2 inches in length. Flowers, according to Swartz, minute; with the petals ovate; and the stamens 10 , and short. Berry subglobose.

This species is remarkable for the size of the leaves. I regret 1 have not met with it in perfect flower.

\section{Miconia bracteata Bracteated Miconia.}

Branchlets compressed densely ferrugineovelutine, leaves broad-ovate cordate at the base shortly acuminate denticulated with the teeth blunt and callous 5-nerved besides a marginal pair bright green above incano-tomentose with a ferruginous tinge beneath, thysse terminal, bractea woolly concave deciduous, stamens 12 , berry 12costate 6-celled.

II A B. Khuna-khuna road, near Milbank.

F L. August.

Leaves about a foot in length, and six inches in breadth, transversely veined, wi h the upper surface bright green: petiole about 3 -inches in length, compressed, ferrugineofarinnse. Thyrse about a foot in length: peduncle compressed, somewhat sulcated, incano-tomentose : branches subdivided. Flowers shortly pedicelled, clustered at the ends of the subdivisions, at first concealed in the bracteæ, 
which are deciduous. Bracteæ, the largest, ovate, acuminate, ahout 4 lines in length; the smaller ones lanceolate. Calyx spherical where it adheres to the ovary, externally hoary and stellato-tomentulose: tube 6-toothed, internally marked with 12 scars indicating the insertion of the stamens, and 6 exterior to them, that of the petals. Petals 6, white. Berry when ripe 12-costate, 6 -celled, size of a pea: seeds minute, ovoid, slightly cuneate, brown, with the surface minutely granular.

This is a large-leaved rank-looking shrub, delighting in damp places. The bracteæ are not so regular as to permit its being placed under Diplochita.

\section{SECT. III. EUMICONIA.}

Calycine tube obovate or turbinate, not globose. Flowers not arranged in a series.

9. Miconia impetiolaris. Apetiolar Miconia.

Branches panicles and under surface of the leaves tomentoso-farinose with the hairs ferruginous and stellated, leaves sessile semiamplexicaul oblong narrowing and subcordate at the base acuminate subdenticulated 5 -nerved besides a very obscure marginal pair glabrous above, thyrse terminal panicled, flowers sessile, calyx obovate with $\tilde{5}$ very short teeth.

Melastoma impetiolaris, Swartz, Fl. Ind. Occ. 788.

H A B. Port Royal Mountains. Near Bath. The Moneague, $\mathrm{Dr}$. Alexander.

Fi. January-May.

A shrub about 8 feet in height: branches few, subsimple, tetragonal towards the extremity. Leaves very large, about a foot in length, and 5 inches in breadth, 5 nerved with an indistinct marginal pair. Thyrse terminal, of nearly the same length as the leaves : branches subtetragonal, farinoso-tomentulose, ferruginous: flowers small, white, crowded, subsessile. Caly x externally farinoso-tomentulose : tube short, with the throat crimson : teeth minute, situated externally below the margin. Petals 
5, oblong, obtuse, concave. Stamens 10 : anthers linear, one-pored. Style erect: stigma depressed. Berry size of a coriander seed, scarlet, 5-celled: seeds numerous, minute, wedge-shaped, angular.

This description agrees with that of Swartz in respect to the leaves which are described by him as 5-nerved, from his reckoning the marginal pair, which he does not usually take into consideration.

This is a very remarkable species, readily attracting notice from the size of the leaves.

\section{Miconia macrophylla. Large leaved Mi- conia.}

Branches panicles petioles and under surface of the leaf-nerves ferrugineo-tomentoso-farinose, leaves subsessile broad lanceolate attenuated at the apex narrowing towards the base and slightly cordate ylabrous above stellato-pubescent beneath, 3-ply-nerved with a marginal pair, remotely denticulated, thyrse panicled terminal, flowers white sessile crowded.

II A B. Damp mountain woods.

F L. Apr.l.

Branches subterete, slightly compressed. Leaves about 8 inches long and 4 inches broad, with the stellated pubescence on the under surface distinct and not matted: petiole 1-2 lines in length. Peduncle tetragonal, slightly suleated. Calyx ferrugineo-farinose, 5 -toothed

This species is usually confounded with the preceding.

\section{Miconia punctulata. Punctulated Mi- conia.}

Branches tetragonal as also the petioles and peduncles cinereo-farinose with a minute pubescence, leaves lanceolate attenuated at the base entire iriply-nerved beside a marginal pair subglabrous except the farinoso-puberulo:is under surface of the nerves, thyrse terminal.

II A B. St. Anns.

F L. March. 
Leaves about 8 inches long and 2 broad, with the marginal nerves so close to the edge as to be obscure. Flowers minute, white, subsessile, crowded, minutely bracteolated. Calyx externally farinose, minutely 5 -toothed with a gland-like apicula on the bark of each tooth. Petals 5, obtuse. Stamens 10 : filaments capillary : anthers onepored. Style erect, longer than the stamens: stigma subcapitate, depressed. Berry black, 5.celled: seeds wedge-shaped, angular.

12. Miconia glabra. Glabrous Miconia.

Branchlets compressed slightly puberulous, leaves lanceolate with the apex obtuse, attenuated at the base so as to be decurrent, 3-ply-nerved without a prominent pair of marginal nerves entire, thyrse terminal, flowers crowded subsessile minutely bibracteolated, calyx obso!etely and obtusely 5-fid, petals 5, stigma incrassated towards the stigma which is depressed, berry 4 (?)celled.

II A B. St. Ann.

F L. January.

A shrub. Leaves very shortly petiolate, glabrous, 3 inches long and one broad. Peduncle and its divisions tomentulose. Calyx very small, turbinate. Petals imbricating, rounded at the apex. Stamens longer than the petals: anthers linear, 1-pored. Berry small, size of a coriander seed, 4 -celled : seeds angular.

\section{Miconia discolor. Discoloured Miconia.}

Branchlets compressed ash-coloured with a russet tinge minutely lepidose, leaves unequal in size lanceolate attenuated at the apex entire glabrous above, argenteo-lepidose with a rufous tinge beneath, 3-nerved with a very obscure marginal pair, thyrse terminal, flowers minute subsessile crowded in clusters, calyx externally rufo-lepidose, pctals ovate acute, stigma subcapitate retuse. 
H A B. Limestone districts-Near the Moneague, $\mathrm{Dr}$. Alexander.

F L. March.

A shrub about six feet in height. Leaves, with the margin in the young entire, in the older leaves denticulated, revolute so as to be concave on the under surface, to the glass minutely punctulated above, densely rufolepidose with a silvery glance beneath, $\mathbf{4 - 5}$ inches long, and rather more than one broad: petiole very short. Peduncle and its branches rufo-lepidose. Flowers minute, crowded on very short branchlets. Calyx turbinate, exterually rufo-lepidose, obsoletely 5 -toothed. Petals $\mathbf{5}$. Stamens 10: anthers one-pored. Style erect. Fruit -?

\section{Miconia prasina. Fragrant Miconia.}

Branchlets towards the extremity subtetragonal and cinereo-farinose, leaves oblongo-lanceolate acuminate attenuated at the base subentire or denticulated 3-ply-nerved besides a marginal pair glabrous, thyrse terminal panicled, branchlets patent, calycine teeth 5 minute, petals concave, stamens 10.

Melastoma prasina, Swartz, Fl. Ind. Occ. 777

H A B. Potosi wood, near Bath. Moortown. Damp Savannahs.

F L. January-March.

A shrub, 4-10 feet in height: branches compressed towards the end. Leaves shortly petiolate, $6-9$ inches in length, oblong, of a livid green colour. Panicle much branched: branches patulous, subdivided : flowers small, white, odorous, subsessile, minutely bracteolated. Calyx somewhat campanulate, externally (to the glass) lepidotopunctulated. Petals 5, oblong, concave, most minutely ciliated, and at the apex crispid. Stamens longer than the petals : anthers linear, minutely biauriculated, 1-pored. Ovary spherical: style erect: stigma subcapitate, glutinose. Berry size of a coriander seed, azure blue, glaucescent, 5-celled.

I am confident that this is the Melastoma prasina of Swartz. The principal difference is that the leaves, according to that Author, are very entire, There are cer- 
tainly no distinct teeth, and the designation subentire would be more applicable.

\section{Miconia lævigata. Common Miconia.}

Branches alternately compressed farinose, leaves ovato-lanceolate attenuato-acuminate rounded at the base minutely denticulated with the teeth setose 5-nerved besides an obscure marginal pair subglabrous, cymes panicled, flowers subsessile subserial, calyx farinose and ciliate, petals concave, berry 5-celled.

Melastoma fruticosa minor, foliis tenuibus ovatis, Browne, 219.-Grossularia fructu non spinoso malabathri foliis oblongo, fructu nigro, Sloane, II. 140.-Melastoma lævigata, Swartz, Obs. 176.

H A B. Common in waste places, mountains.

F L. Early part of the year.

A shrub about 10 feet in height. Leaves about 6 inches long and $2 \frac{1}{2}$ broad, thin, membranaceous, shiring and bright green above, paler beneath: petiole an inch in length, terete, slightly channelled above. Thyrse terminal, of nearly the same length as the leaves: peduncle and its divisions farinose : flowers small, white, subsessile, sub-serial. Calyx externally farinose, ciliated, minutely 5-toothed, very obscurely 10-nerved. Petals 5, rounded at the apex, concave. Stamens 10 , white, anthers onepored. Style longer than the stamens : stigma obtuse. Berry small, black, 5-celled, size of a coriander seed: seeds oval.

The leaves in this species, previous to dropping, assume a scarlet hue. They are sometimes more or less hispidulous. The berry is observed in some specimens to have a ribbed appearance.

\section{Miconia affinis. Acute-leaved Miconia.}

Branchlets compressed sulcated densely ferrugineo-farinose, leaves elliptic acute at both ends denticulated 3-nerved besides the marginal pair 


\section{subglabrous, panicle terminal, calyx 5-fid.}

II A B. Near Moneague, Dr. Alexander.

F L. A pril.

Leaves about 8 inches long and 4 broad, with the apex blunt, glabrous, except the under surface of the nerves; transverse nerves strongly marked; teeth of the margin not setose as in the preceding species. Flowers shortly pedicelled. Calycine teeth deltoid, acute. Berry size of a coriander seed.

This, differs from M. Lavigata in the leaves being thicker, and acute at both ends; the transverse nerves are also stronger marked.

\section{Miconia elliptica. Broad-leaved Mi- conia.}

Branches compressed slightly sulcated ferrugineo-velutine as also the peduncles and petioles, leaves elliptic nartowing towards the petiole shortly attenuato-acuminate denticulated 3nerved besides a marginal pair subglabrous, thyrse terminal, flowers crowded subsessile, stamens longer than the petals.

H A B. Road over Khuna-khuna pass, Bath. Rev. T. Wharton. Moneague, $\mathrm{Dr}$. Alexander.

F L. March-A pril.

The branches are much flattened. Leaves thin, $\mathbf{7 - 6}$ inches long, and $\mathbf{3 - 4}$ broad, acute at the base, more or less indistinctly denticulated, slightly farinose along the under surface of the nerves, thin: petiole half an inch in length. Peduncle and its divisions compressed, ferrugineo-farinose. Flowers have a feathery or hairy aspect from the length of the stamens. Calyx 5-rarely 6-toothed, minutely bracteolated: externally ferrugineo-farinose. Petals 5, rarely 6, oblong, concave, reflected. Stamens 10: filaments capillary: anthers arcuate, biauriculated at the base, 1-pored. Style slender: stigma umbilicated Berry size of a coriander seed, yellow, with the tubular portion of the calyx circumcised, 4-celled: seeds minute, wedge-shaped.- The lateral nerves form an arch unusually distant from the mid-rib. 


\section{Miconia palustris. Marsh Miconia.}

Branchlets subterete slightly channelled glabrous, leaves lanceolate entire glabrous 3-plynerved without a marginal pair, petiole winged with the decurrent leaf, panicle terminal with the peduncle cinereo-pruinose, calyx minutely 5toothed incano-pruinose, stigma excavated.

H A B. Marsh near Grosmond, St. Elizabeth's $D r$. MacNab. Marsh near Moneague, Dr. Alexander.

F L. March.

Leaves about 4 inches in length and one in breadth, unequal at the base, subsessile. Divisions of the peduncle tetragonal: branches very patent, brachiate: flowers small, subsessile, clustered, bracteolated. Petals 5, rounded at the apex. Stamens 10: filaments capillary: anthers minutely biauriculated at the base, 1-pored. Style erect. Berry black, size of a coriander seed, 5celled: seeds wedge-shaped

The leaves are plane, and have a greasy feel and appearance, and resemble those of the Bucida Buceras.

19. Miconia microcarpa. Small-fruited Miconia.

Branchlets tetragonal pale-ferruginco-velutine; leaves broad-'anceolate subacuminate slightly attenuated at the base subrepando-denticulated subglabrous 5-nerved, thyrse terminal much branched, limb of the calyx short truncated, fruit obscurely 10-ribbed.

Melastoma lævigata, Aubl. Guian. 412. t. 159.-Miconia microcarpa, DC. Prod. III. 189.

H A B. Moneague, Dr. Alexander.

F L. March.

Leaves shortly petiolated, with minute scattered stellated hairs above, paler and subglabrous beneath.

Vor. 2. 
Branches of the panicle long, pale-ferruginous and velutine, compressed. Flowers minute, bracteolated, crowded, sessile.

\section{Miconia pyramidalis. Pyramidal-flow- ering Miconia.}

Branchlets tetragonal sparingly ferrugineofarinose, leaves broad-lanceolate rounded at the base acute 3-nerved beside a marginal pair subglabrous above sparingly hispidulo-farinose beneath obscurely denticulated, thyrse terminal with its branches brachiate, petals 5 oblong reflected, berry minute.

II A B. Near the Moneague, Dr. Alexander.

F L. March.

Leaves with the margin revolute, and with the teeth setose. Peduncle tetragonal, farinoso-puberulous : branchlets short. Flowers small, white, subsessile, minutely bibracteolated. Calycine teeth 5 , minute, obtuse, with a green prominence on the back of each. Petals obtuse, reflected. Stamens 10: anthers one-pored. Style longer than the stamens: stigma obtuse. Berry crowned with the tubeless calyx.

21. Miconia parviflora. Small-flowered Miconia.

Branches subrotund slightly (when young) ferrugineo-farinose, leaves oblongo-lanceolate slightly rounded at the base attenuated at the apex subentire or obscurely denticulated 3-nerved besides an obscure marginal pair glabrous above hispidulous along the nerves beneath, thyrse terminal, flowers small subsessile, calyx 5-toothed, berry minute 5-celled.

HA B. Khuna-Khuna road from Bath. Reverend $T$. Wharton.

F L. A A ril.

A shrub about 8 feet in height. Leaves about 3 inches 
long and rather more than 1 broad, membranaceous, hispidulous with minute stellated hairs along the under surface of the nerves: petiole one third of an inch in length. Peduncle and its divisions farinoso-puberulous. Flowers very small, white. Petals oblong. Stamens 10, erect. Berry size of a small coriander seed, 5-celled.

\section{XiV. Cremanium.}

Calycine tube campańulate or obovate adhering to the ovary; limb persistent, 4-5 toothed. Petals 4-5, obovate. Stamens 10, equal: anthers short, somewhat wedge-shaped at the base, without auricles, obtuse and bi-porose at the apex. Style filiform: stigma orbiculato-peltate. Capsule berried, 3-5-celled : seeds angular or ovate, with the hilum linear.

Name, from $x_{\S} \varepsilon \mu \alpha \omega$ to suspend; in allusion to the form of the anthers, being attenuated at the base, and enlarged towards the apex like pendants.

\section{Cremanium rubens. Erubescent Crema- nium.}

Very glabrous, branchlets tetragonal sulcated, leaves ovato-lanceolate acuminate denticulated 3-nerved, panicle terminal subracemose, flowers diœcious 8-10-androus crowded.

Melastoma foliis ovatis minutissime denticulatis, venis et ramulis purpurascentibus, Browne, 219.-M. rubens, Swartz, Fl. Ind. Occ. 797.-Cremanium rubens, $\boldsymbol{D C}$. Prod. III. 797.

II A B. Cold damp situations, higher mountains.

F L. August.

A shrub 6-10 feet in height: branches suberect, glabrous : branchlets reddish. Leaves decussating, attenu. ated at the apex which is reflex, minutely and distantly denticulated, sub-rigid: " petiole sulcated, coloured, with a small roundish glandule-like prominence on each side at the insertion. Peduncle tetragonal: divisions short, patent, subdivided, coloured. Flowers minute, numerous, 
crowded, shortly pedicelled, diœcious. \& Flowers deciduous. Calyx coloured, $5(-4$ ? )-toothed : teeth very minute. Petals rounded, white. Filaments $10(-8$ ?), twice the length of the corolla : anthers white, bi-porose. Rudiments of the pistil in the centre. of Flowers. Calyx as above. Petals 5, minute, white, roundish, concave, appressed to the style. Stamens 10 (-8?), imperfectly developed, abortive, shorter than the calyx. Style erect : stigma capitato-depressed. Berry size of a coriander seed, azure, 5-celled.

\section{Cremanium axillare. Axillary-flowered Cremanium.}

Branchlets subtetragonal, when young ferrugineo-farinose, when old glabrous, leaves ellipticolanceolate acuminate cbsoletely serrulated 3-plynerved besides the marginal pair glabrous, thyrse axillary racemose short, calyx $\mathbf{4}$-toothed, petals 4, stigma obtuse.

II A B. St. Ann's, near the Moneague.

F L. $\Lambda$ pril.

Leaves glabrous except a minute villous tuft in the axils of the under surface of the nerves, about 4 inches in length and $1 \frac{1}{2}$ broad: petiole faririoso-puberulous near the leaf, nearly an inch in length. Panicles scarcely more than an inch in length. Flowers small, white, crowded at the ends of the subdivisions of the peduncle, very shortly pedicelled, each furnished with a pair of minute bracteoles. Calycine teeth indistinct. Petals obtuse, concave, reflected. Anthers oblong, tapering at the base, bi-porose. Ovary sheathing around the base of the style: style erect: stigma obtuse.

\section{Cremanium? glandulosum. Glandulose Cremanium.}

Branches obiusely tetragraal aibiado-tonentose, leaves ovate 3-nerved entire strigose above, hirsuto-hispid and glandulose beneath, racemes terminal, flowers crowded s' nute.-DC. 
Melnstoma g landulosa, Swartz, Fl. Ind. Occ. 799.

II A B. High Mountains.

F L.

Swartz states that the brarchlets are disfigured by the scars of the old leaves: that there is a fascicule of hairs (glandules?) in the axils of the leaves: and that the petioles are very hairy.

\section{Cremanium rigidum. Stiff-leaved Cre- manium.}

Branches stiff tetragonal ferrugineo-pulverulent, leaves ovate rounded and subcordate at the base obtuse denticulated 3-nerved stiff fragile glabrous, panicle terminal many-flowered ferrugineo-hirsute, flowers decandrous, petals ovate white, stamens longer than the petals.

Melastoma rigidum, Swartz, Fl. Ind. Occ. 768.

II A B Summit of the Blue Mountain range.

P L, June.

About 6 feet in height. Branchlets coloured. Leaves about 3 -inches long, and 2 broad, submembranaceous, glabrous except the under surface of the nerves which is scabrons: petiole about half an inch long. Panicle ter. minal length of the leaves, compound. Flowers pedicelled, white. Calycine teeth incurved after flowering, persistent. Petals 5, ovate, obtuse, concave, rather thick. Anthers bi-porose. Style short, thick, striated: stigma subcapitate, pubescent. Berry subrotund.

\section{Cremanium integrifolium. Entire-leaved Cremanium.}

Branchlets compressed ferrugineo-velutine, leaves oblong acuminate rounded at the base very entire 3-nerved besides the marginal pair glabrous except the under surface especially of the nerves which is sparingly and minutely stella. to-puberulous, thyrse terminal, branches short simple 4-6 flowered, flowers sessile, stamens 10. 
H A B. St. Ann's, Dr. Alexander.

F L. February-A pril.

Leaves thin, membranaceous, about 6 inches long and $2 \frac{1}{2}$ broad: petiole less than an inch in breadth. 'Thyrse shorter than the leaves. Flowers crowded, sessile, rather small. Branches of the peduncle tetragonal, tomentulose. Calyx externally tomentulose, 5-fid, with the lobes afterwards connivent. Petals rounded at the apex, somewhat clawed. Anthers 2-pored, subauriculated at the base. Style long : stigma excavated.

Were it nnt for the anthers being bi-porose, I would refer this to the second section of Mrconia.

\section{Cremanium trinerve. Three-nerved Cre- manium.}

Very glabrous, branchlets subtetragonal coloured, leaves elliptico-lanceolate acuminate with the apex obtuse minutely serrulated 3-nerved besides an obscure marginal pair membranaceous, thyrse terminal, flowers decandrous.

Melastoma trinervis, Swartz, Fl. Ind. Occ. $\mathbf{7 7 4}$.

H A B. Mountain thickets.

F L. Early in the year.

A shrub, 6-8 feet in height: branches terete. Leaves about 4 inches long and $1 \frac{1}{2}$ broad, with the nerves on the under surface coloured (red) : petiole slightly channelled, very glabrous, coloured. Thyrse terminal, shorter than the leaves, sessile: peduncle tetragonal, glabrous: branches decussating : flowers numerous, crowded, white, in threes, subsessile. Calyx subglobose : teeth 5 , minute. Petals 5, oval. Stamens 10, longer than the petals; anthers 2-pored: Style length of the stamens: stigma obtuse.

\section{Cremanium splendens. Showy Cremanium.}

Branches terete glabrous towards the extremity ferruginous, leaves oblong acuminate entire 5-nerved including the marginal pair glabrous shining above, flowers panicled subumbellated 
subsessile small, calycine teeth 5 , petals 5 ovate white, stigma capitato-depressed, berry minute azure-blue.

Melastoma splendens, Swartz, Fl. Ind. Occ. 798.

II A B. Mountain woods.

F L. Autumn.

\section{Blakea.}

Calyx campanulate, surrounded at the base with 4-6 broad scales arranged in a cruciate or triple order, with the limb persistent, membranaceous, 6-lobed or 6-dentate. Peta.s 6. Anthers large, connected in a ring, obtuse and hiant with two pores at the apex, furnished at the Lase with a short spur-like process. Capsule berried, crowned with the calyx, 6-celled: seeds ovatoangulated.-DC.

Named by Dr. Patrick Browne in honor of Mr. Martin Blake of Antigua, a promoter of science, and a patron of the Doctor's Natural History of Jamaica.

\section{Blakea trinervia Three-nerved Blakea.}

Leaves oblongo-ovate 3-nerved, when adult glabrous and shining, when young serrulated and rufo-tomentose especially the under surface of the nerves, peduncles solitary longer than the petiole, scales longer than the calyx.

Blakea foliis ellipticis, Browne, 323. t. 35.-B. trinervia Su'artz, Obs. 188.

II A B. Mountain woods.

F L. Throughout the year.

A shrubby tree of irregular growth: branches supporting themselves on neighbouring shrubs or rocks : rufotomentose at the extremity. Leaves opposite, petiolate, oblongo-ovate, subacuminate, subentire (minute teeth to be detected within the margin on the under surface,) very glabrous above, slightly hirsute especially along the nerves and minutely punctulated beneath: petiole ierete, 
rufescenti tomentose. Peduncles axillary, solitary, more than twice the length of the petiole, terete, hirsute, oneflowered. Fales 6 , in pairs, roundish, concave, coloured, ciliated with rufous hairs, concealıng the calyx. Ca!ycine lobes 6, suberect, obtuse, crimson, ciliated. Petals 6, thick, coriaceous, very glabrous, of a bright crimson, twice the lerigth of the scales, deciduous. Stamens 12; filaments tæneaform, thin, crimson: anthers yellow; pollen a fine white power. Style lunger than the stamens, ro* bust, subulate, crimson: stigma simple.

The description of Swartz is very inaccurate.-This is one of the most beautiful of the wild plants of our forests, and is commonly designated the "Jamaica Rose." There must be some difficulty in its cultivation, as it has not yet found a place in our Gardens ; although it is very common in our inountains, sending its roots into the clefts of the rocks, by the waysides. We are informed by writers on Horticulture, that plants of this genus, grow well in peat, or peat and loam mixed, and that cuttings, taken from quite ripened wood, planted in sand, and plunged in a moist heat, root readily.

Tribe IV. CHARIANTHEAE.

Anthers bilocular, opening by a double longitudinal cleft. Fruit fleshy. Seeds wedge-shaped, angular.

\section{Chenopleura.}

Calyx adnate to the ovary; limb obtuse, 5 toothed. Petals 5, subrotund. Stamens 10, scarcely longer than the petals. Anthers longitudinally bi-rimose, with the connective at the base obtusely biauriculated. S1yle clavate : stigma orbiculate, subumbilicated. Berry? 3-4celled : seeds? $-D C$.

Name from $\chi$ awv to split open, and $\pi \lambda \varepsilon u g a$ the membrane lining the cavity of the thorax.

\section{Chænopleura quadrangularis. Quadran- gular Chrenopleura.}

Branches tetragonal slightly sulcated glabrous 
leaves ovato-lanceolate attenuato-acuminate round ed at the base entire 3-nerved besides an obscure marginal pair subglabrous, thyrse longer than the leaves with the branches fastigiate, stamens 10, style twice the length of the calyx.

Melastoma quadrangularis, Swartz, Fl. Ind Occ. 776.

II A B. Blue Mountain range.

F L. February-May.

About 12 feet in height. Leaves 5-6 inches long and $1 \frac{1}{2}$ broad, decussating, dark green and minutely punctulated above, lepidose with a yellow tinge beneath: petiole an inch and a half long, coloured. Thyrse erect : branches 3-chotomous. Flowers white, small, with a yellowish tinge, subsessile. Calycine teeth 5. Petals oval. Anthers bursting longitudinally. Style twice the length of the calyx: stigma capitate, umbilicated, depressed. Fruit size of a coriander seed, purple, pruinose.

\section{Chænopleura Stelligera. Stellated Chæ- nopleura.}

Branches compressed tetragonal ferrugineofurfuraceous with minute stellated hairs, leaves oblongo-ovate subcordate minutely glandulosodentate 3-nerved, thyrse terminal, flowers decandrous, style striated, berry spherical ferrugineofarinose.

H A B. Portland woods.

F L. April.

A shrub about 8 feet in height. Leaves subacuminate, stiff, fragile, glabrous with exception of the under surface of the nerves which is ferrugineo-scabrous, 6 inches long and $2 \frac{1}{2}$ broad: petiole terete. Panicle erect; peduncle and its divisions ferrugineo-tomentose. Flowers pedicelled: pedicels half an inch in length, bracteolated. Calyx ferrugineo-hirsute, 5-toothed. Petals 5, obovate, concave, reflected. Stamens longer than the petals : filaments tæneiform: anthers oblong, white, opening by a longitudinal fissure, being widest at the apex: pollen white. Style angular: stigma simple. Berry size of a

VoL. 2. 
currant, crowned with the calyx, externally of a bloodred rust colour, farinose, 2-3-celled: seeds numerous, ovate, wedge-shaped.

3. Chænopleura stenobotrys. Strict-clustered Chanopleura.

Very glabrous, leaves oblongo-lanceolate obtuse at the base acuminate at the apex denticulated with distant ciliiform serratures 3-nerved (approaching to triply-nerved), thyrse terminal elongated, branchlets opposite generally racemose, flowers white tinged with pink, bracteoles and calycine teeth very minutely ciliolated.-DC.

Melastoma stenobotrys. Richard, in Bonpland. Melast. t. 30 .

II A B. A native of the mountains of Hispaniola, and probably also of Jamaica.

F. L.

\section{MELASTOMACER OMISSAE.}

Thore are several omissions relating to the plants of this order, which I have considered preferable to supply now, rather than to delay till the completion of the work.

\section{Tribe II. RHEXIAE. \\ XVII. Adelobotrys. \\ (To follow Spennera $p$. 43.)}

Calyx free, subcampanulate, shortly and obtusely 5-tuothed. Petals 5, oval. Stamens 10: anthers bifurcated at the base, bi-porose. Ovary oblong, pubescent: style thick: stigma obtuse Capsule oblong, 5-celled, bursting in five directions, with the column at length free, and terminating in $\mathbf{5}$ fibres originally constituting the style.

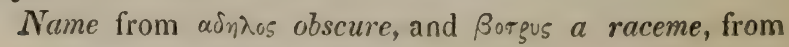


the characters of the genus, at the time when established, being imperfectly known.

\section{Adelobotrys scandens. Scandent Adelo. botrys.}

Melastoma scandens, Swartz, Fl. Ind. Occ. 772.-Aubl. Guian. i. 435. t. 172,-Adelobotrys scandens, DC. Prod. III. 127.

H A B. Damp mountain woods.

TL. April.

Shrubby, $20-30$ feet in height, attached by fibrous roots to the stems of trees, terete, sparingly branched : branches subtetragonal, sparingly ferrugineo-pubescent when young. Leaves opposite, petiolate, broad-ovate, acuminate, narrowing towards the base rufo-ciliated and obscurely denticulated, 5 nerved including the marginal pair, nervosobullate, shining above, occasionally setose along the under surface of the nerves, 3-5-inches long: petiole rather short, ferragineo-pubescent, with a stipulary line of hairs connecting on each side the petioles. Racemes terminal: common peduncle tetragonal, ferrugineo-pubescent : divisions bearing in an umbellule or cyme $8-10$ shortly pedicelled showy flowers, white tinged with pink. Calyx small, subcampanulate: limb spreading, obscurely and bluntly 5 -toothed, minutely puberulous. Petals 5 , oblong, obtuse, concave. Stumens 10, declinate: filaments broad, purple : anthers bifurcated (bi-setose), and biporose at the apex, with the connective embracing, twice the length of the anthers, subulate, membranaceous. Ovary oblong, pubescent: style thick: stigma obtuse, pruinose. Capsule oblong, striated, 5 -celled, crowned with the truncated pentagonal calyx.

This is a very beautiful plant, readily attracting the eye in our damp woods, especially on the North-Side of the Island.

\section{Tribe iII. MICONIAE (p. 43.) \\ 4. Clidemia agrestis. Wild Clidemia.}

(Place of insertion, after C. StrigluLosa, p. 45.)

Branchlets tetragonal hirsute, leaves ovate acuminate rounded and subcordate at the base ser- 
rato-crenated and undulated 5-nerved without a marginal pair hirsute, racemes axillary few-flowered, pedicels hairy, calyx pentagonal, stamens 10.

\section{H A B St. Ann's. Dr. Alexander.}

F L. March.

Branches slender. Leaves about 6 inches long, and 2 broad. Panicle not more than an inch in length, 10-12. flowered. Pedicels filiform, 3.6 lines in length. Calyx strigoso-hirsute with long stiff hairs: lobes about 3 lines in length, filiform, hairy. Alibastrum conical. Petals 5, oblong, rounded at the apex. Anthers 1-pored, linear, attenuated at the apex. Style surrounded at the base with a circle of connivent setæ, contracted near the stigma: stigma capitate, depressed, minutely granular. Berry 5celled, very hairy.

\section{Ossæa micrantha. p. 49.}

Racemes scarcely longer than the petiole; primary branches trifid; extreme branches bifid. Pedicels about three lines in length. Berry when dry 8-ribbed, 4-celled, juiceless, so that the seeds, which are very numerous, drop out like powder, when the cells are opened.

I have been enabled to complete the description of this plant from specimens collected in the neighbourhood of of the Moneague by Dr. Alexander.

11. Sagræa aureo-sericea. Aureo-sericeous Sagraa.

(Place after S. Berteri, $p$. 54.)

Branches compressed sulcated denisely tomentose as also the leaves petioles and peduncles with hairs of an aureo-ferruginous hue and of a silky appearance, leaves ovate acuminate rounded and somewhat attenuated at the base denticulated 5-nerved hirsute, peduncles axillary, cyme few-flowered, calycine segments subulate,

II A B. St. Mary`s woods.-Dr. NacNab. 
F L. October.

Leaves about 6 inches long, and $3 \frac{1}{2}$ broad, paler on the under surface: petiole an inch or more in length. Peduncle subdivided. Flowers minute. Calyx hairy.

\section{Harrera pedunculata. Long-stalked Ha- rera. (p. 63).}

Branches subtetragonal subglabrous (when young minute velutine, ) leaves elliptic attenuatoacuminate subacute at the base 3-ply-nerved entire glabrous above, minutely velutino-tomentose with a villous tuft in the axils of the nerves beneath, thyrse terminal panicled longer than the leaves, stamens 10 berry 3-celled.

I A B. Fairfield, Manchester. Rev. H. R. Wullschlagel. F L. A pril

Branches of an olive-green colour. Leaves about $3 \frac{1}{2}$ inches long and $1 \frac{3}{4}$ broad: petiole nearly an inch long. Branches of the panicle erect, fastigiate, Calycine lobes 5, obtuse. Petals 5, rounded, reflected. Stamens 10 : anthers one-pored, scarcely auriculated at the base. Style longer than the stamens, declinate, slightly curved: stigma simple. Berry size of a large pea, three-celled; seeds numerous, dropping out like a coarse powder when the cells are opened.

\section{Conostegia gloriosa. (p. 68.)}

Dr. Alexander found this beautiful species growing abundantly in the neighbourhood of the Moneague. From specimens supplied by him, I find the fruit to be 6-celled.

NOTE.-In order to facilitate an acquaintance with the Melastomaceous plants of this Island, I have arranged, in the following table, the different species, 1 st according to the number of Stamens; and 2ndly subdivided them according to the Nervation. 
a. Octandrous.

* triply-Nerved.

1 Calycogonium glabratum

2 Ossæa scabrosa

3 - pratensis

4 - purpurascens

5 Sagræa virgata

6 bracteolata

7 Tetrazygia Fadyeni

8 - ecostata

9 Creman:um axillare

\section{* * TRI-NERVED.}

10 Spennera aquatica

11 Ossæa micrantha

12 Sagræa fascicularis

13 capillaris

14 - hirtella dumosa

16 microphylla

18 Tetrazyg tetrandra

19 - angustifolia

20 Harrera trinervis

21 Cremanium rubens

63

91

22 - glandulosum

92

23

rigidum

24 integrifolium

93

25 trinerve

*** FIVE-NERVED.

26 Sagræa Berterii

$27 \longrightarrow$ pilosa

28 aureo-sericea

29 Tetrazygia hispida

30 - discolor

58

31 Harrera sparsifolia

32 Heterotrichum octandrum 
35 Henriettea ramiflora

36 - grandifolia

37 racemosa

38 Miconia macrophylla

76

84

39 - punctulata

40 - glabra

41 prasina

42 palustris

43 Harrera pedunculata

84

85

86

89

89

* * TRI-NERVED.

44 Meriania leucantha

45 - rosea

46 - purpurea

42

47 Harrera gerascanthoides

61

48 Diplochita rosea

78

49 Miconia verticillata

79

50 - serrulata

51 holosericea

79

75

52 discolor

85

53 affinis

54.- elliptica

87

88

55 - pyramidalis

56 - parviflora

57 Chænopleura stelligera

90

90

97

58 - quadrangularis

$59-$ stenobotrys

96

98

* * * FIVE-NERVED

60 Clidemia hirta

61 _ strigillosa

62 - agrestis

63 Heterotrichum dubium

64 Diplochita Swartziana

65 - Fothergilla

66 Miconia circumsecta

67 rufescens

80

68 - elata

81

69 - argentea

70 __ impetiolaris

82

71 _ lævigata

72 - microcarpa.

73 Adelobotrys scandens 
c. Dodecandrous.

* TRIPLY-NERVED。

74 Conostegia alternifolia

75 Blakea trinervia

* * TRI-NERVED.

76 Conostegia gloriosa

68

77 Conostegia procera

69

78 — formosa

70

79 - montana

70

80 glabra

71

81 Conostegia subhirsuta

67

82 Miconia bracteata

82

83 Heterotrichum patens

64

84 - viscosum

65

\section{ORDER LXXIX. MYRTACER-THE MYRTLE FAMILY.}

Calyx 4-6, more frequently 5-cleft, the limb semetimes cohering at the apex and falling off like a lid; æstivation valvate. Petals attached to the calyx, equal in number to its segments, with a quincuncial æstivation, rarely none. Stamens inserted with the petais either twice as many or $\infty$, rarely equal to them in number : filaments distinct, or united in one or more parcels, curved inwards before flowering: anthers ovate, 2-celled, bursting longitudinally. Ovary inferior, 1-2-4-5-or 6-celled: style simple, derived immediately from the placenta: ovules anatropal, pendulous or erect. Fruit either dry or fleshy, and amphitropal or indehiscent: seeds usually indefinite : embryo exalbuminose.

Trees or shrubs ; with opposite, rarely alternate, leaves, usually entire and pellucido-punctulated. They are na- 
tives chiefly of inter-tropical countries. The wood is generally white and compact; in some cases it is darkbrown, hard, and heavy.

The following exotic species have been introduced, and have become in a great measure, naturalized in the Island.

\section{Syzygrum Jambolanum. The Jambolana Tree.}

This bears a fruit resembling the damson in form and appearance; is grateful to the taste, having, with the sweetness, a pleasant sub-acid flavour, combined with some astringency. It is a native of the East Indies. It is common in gardens near Kingston, and is to be met with in some of the hottest situations of the Island.

\section{Jambosa vulgaris. Rose Apple,}

This is common in pastures in the cooler and more seasonable districts. In such situations it may be found completely naturalized. The fruit is strongly impreg. nated with the odour of the rose: but is otherwise insipid, and is never made use of as an article of the dessert. The young branches are long and undivided, and are well-adapted for the handles of chaise whips. The bark of the root has the credit of being a virulent poison. 'I'his is, I am confident, a popular mistake.

\section{Jambosa purpurascens. The Otaheite Apple.}

A low tree, seldom exceeding 25 feet in height, conical in its form, having a handsome appearance, particularly when its branches are covered with a profusion of crimson flowers, strewing the ground beneath, when they drop, so as to form as it were a rich carpeting. The fruit is pear-shaped, of a crimson hue, and occupies a higher place than the rose apple as an edible fruit, though it is rather watery and insipid. It thrives in the more seasonable parts of the Island, especially at Bath, where an avenue formed by them along the principal street is very ornamental. Like the preceding species it was introduced from the East Indies.

VOL, 2, 


\section{Caryophyllus aromaticus. The Clove.}

On different occasions plants of this valuable tree have been introduced into the Island; but the cultivation has not as yet been successful, for I have reason to believe that it has not been propagated from seeds, produced in the country. It is very different with the Nutmeg, (MYRISTICA OFFICINALIs) young plants of which have been very freely distributed, from seeds grown at the Bath Botanic Garden.

\section{Psidium.}

Calyx with the limb, previous to the opening of the flower, entire; afterwards 1-5 cleft. Petals 5. Stamens $\infty$, inserted in a broad circle and crowded on neariy the entire undivided surface of the limb, free. Ovary 5-20-celled. Berry crowned with the hardened limb, of the calyx, many-seeded: seeds nidulant in pulp.

Name derived from $\pi \sigma_{1} \delta$ iov, one of the Greek appellations of the pomegranate, to which, from the number of the seeds and colour of the pulp, the common guava was supposed to bear a resemblance.

\section{Psidium pyriferum. The Guava.}

Branchlets tetragonal, leaves oblong obtuse with an apicula subcordate, pubescenti-velutine beneath, pedicels one-flowered, fruit pear-shaped.

Malo punicæ affinis pomifera, flore pentapetalo albo, fructu nullis dissepsimentis interstincto, ex-toto esculento, majore albo. Sloane II. 163.-Psidium fruticosum, Browne, 238.-Guayava pyriformis, Gartn. Fruct. I. 38.

HA B. Common every where, especially in pastures and by the road-sides.

F L. Throughout the year.

A low shrubby tree, seldom more than 15 feet in height, with a smooth ash coloured bark. Young branches with the ang!es sub-alatc, pubescenti-velutine. Leaves about 
4 inches long, and $1 \frac{3}{4}$ broad, oblong, sub-cordate at the base, rounded and apiculated at the apex, when young puberulous above, and pubescenti-velutine beneath; nerves strongly marked on the under surface, rendering the upper rugulose: petiole about two lines in length, pubescenti-velutine. Peduncles axillary, solitary, one flowered.

It is remarkable, that, respecting a plant so common, there should be any uncertainty. Sloane describes three kinds of Guava; 1st, the red ; 2nd, the large white ; and 3rd the small white. These appear to me to belong to one species, the varieties being the consequence of soi and climate. Where the soil is rich and the climate favorable, the fruit is large and juicy with a sweet reddish pulp. Where the tree is stunted, the fruit is deteriorated, the pulp is pale, and the flavour is acid and austere.

The finest Guavas I have ever seen were some that were produced in the river-course near Dallas Castle, Port Royal, and others in the Morass near Bye-brook, St. Thomas in the Vale:

The form of the fruit, I may here remark, is globular, and resembles that of the apple more than that of the pear: being still more like that of the pomegranate. The characters, given by DeCandolle as belonging to Psidium pomiferum, do not: apply to our Jamaica Guavas.

The bark possesses the tannin principle, and has been found useful in tanning leather; though it is not genewally employed for that purpose. A decoction of the bark the young leaves and the fruit, from being astringent; has been given as a remedy in diarrhœa and dysentery.

The fruit when in perfection has the size and the ap. pearance of the golden pippin. That of the superior sorts is well deserving of a place at the dessert. It is in my opinion, one of our fruits most likely to be ameliorated and improved by cultivation. Its flavour is very peculiar, unlike that of any other fruit. Prepared by stewing as a conserve, and with the addition of milk, it is cqual if not superior to the much vaunted strawberries and cream of Europe. The jelly prepared from it, surpasses that obtained from any other fruit.

The Guava tree is an obstinate weed in pastures, requiring the troublesome operation of grubbing for its eradication. At the same time, it is deserving of remark, that every description of domesticated animal is fond of the 
fruit. It is well-known that hogs become very soon fat from feeding on Guavas, and that a peculiar flavour is imparted to the flesh.

\section{Psidium montanum. Mountain Guava.}

Branchlets tetragonal, leaves ovali-oblong acuminate very glabrous, peduncles many-flowered, fruit spherical.

Psidium arboreum maximum, foliis ovatis nitidisBrowne, 238-P. montanum, Swartz, Fl. Ind. Occ. 879.

II A B. Mountain Forests.

I L. May-June.

A lofty tree, sometimes attaining the height of 100 feet; the bark very smooth, ash-coloured: branchlets tetrago. nal. Leaves $2 \frac{1}{2} \cdot 3$ inches long, and $1 \frac{1}{4}$ broad, subentire or obsoletely and distantly crenulated : petiole quarter an inch in length, coloured. Flowers towards the end of the branches, axillary. Peduncles nearly an inch in length. Calyx internally white, sericeo villous, bursting irregularly into 2-3 divisions. Petals ovate, convex, veined spreading. Stamens very numerous, shorter than the petals. Ovary pyriform, retuse : style subulate: stigma simple, obtuse puberulous. Berry size of a cherry.

The flowers have the odour of bitter almonds. The fruit is sour. The wood is highly esteemed, affording a timber of the hardest description, with the grain beautifully variegated.

3. Psidium fragrans. Fragrant-flovered Guava.

Branchlets subtetragonal, leaves elliptico-lanceolate subacuminate entire, peduncles axillary solitary 1-flowered.

II $\perp$ B. Pastures, Salt Hill, Port Royal Mountains.

F L. January.

A tree about 20 feet in height: bark very smooth, ashcoloured: branchlets subtetragonal. Leaves about $\mathbf{3}$ inches long, and 1 broad, with the apex obtuse, shining above, indistinctly nerved and veined: petiole short. Flowers rather large, size of those of the common Guave, 
whitc, very fragrant. Peduncle about an inch in Iength. Calyx irregularly 3-4 cleft: divisions rounded, concave, internally minutely sericeo puberulous. Petals 5, concave, reflected, roundish, ova!. Stamens very numerous. Ovary turbinate, excavated at the apex: style truncated or awanting. Fruit?

\section{Mrreia。}

Calycine tube subglobose, very rarely ovate: limb 5 partite. Petals 5. Stamens $\infty$, free. Ovary 2-3-celled: cells many-ovuled. Berry when ripe not unusually 1-2-celled, 1-2-seeded. Seeds subglobose, with a thin shell: cotyledons leafy, corrugato-contortoplicate- $-D C$.

Name from Myrsine, an Athenian damsel, a favorite of Minerva, changed by her into a Myrtle.

\section{Myrcia acris. Wild Clove, or Bay-berry Myrtle.}

Peduncles axillary and terminal trichotomous corymbose longer than the leaf compressed, flowers כ̆-fid, leaves elliptic obtuse convex coriaceous very glabrous with elevated reticulated veins on the upper surface very minutely pellucido-punctulated.

Caryophyllus, aromaticus Indiæ occidentalis, Pluk. Alm. 18. t. 155. f. 3.-Caryophyllus, 1. Broune 217,-- Myrtus acris, Swartz, Fl. Ind. Occ. II. 909-- Myrcia acris DC. Prod. III. 243._Hooker, Bot. Mag. 3153

II A B. Dry Hills.

F L. July.

A tree 30.40 feet in height: bark of a greyish brown colour. Leaves opposite, shortly petiolated, 3-5 inches long. Panicles axillary, on elongated peduncles : peduncles compressed: divisions brachiate, each subtended by opposite small deciduous bracteæ. Calyx punctulated: lobes 4-5, obtuse, sprcading, downy within. Petals 5, nearly orbicular, scarcely clawed. Stamens $\infty$. Ovary 2-celled: cells 1-ovuled; style longer than the stamens: 
stigma obtuse. " Berry crowned, size of a large pea, 2-4. seeded. Swartz."

This receives in some places the name of "the Wild Cinnamon." Its Haytien name is "Bois d' Inde."

\section{Calyptranthes.}

Calycine tube obovate : limb previous to flowering entire, afterwards separating at the base and forming a lateral and eventually deciduous operculum. Petals O, or 2-3, very small. Stamens $\infty$ : filaments capillary: anthers small, round, bilocular. Style single : stigma simple. Ovary $\mathbf{2 - 3}$ celled; cells at the central angle $\mathbf{2}$ ovuled. Berry by abortion 1-celled, 1-4-seeded. $-D C$.

Name from $\times a \lambda u \pi r g o v$ a lid, and avoos a flower, in allusion to the peculiar form of the calyx.

1. Calyptranthes rigida. Stiff-leaved Calyptranthes.

Arborescent dichotomously branched, leaves ovate subacute at the base slightly convex glabrous, peduncles interpetiolar for the most part simple subtriflorous occasionally trichotomouslysubdivided with the central branch 3 -flowered, the lateral ones 1-2 flowered.

Swartz, Fl. Ind. Occ. 923.

H A B. St. Catherines' peak. Gap below Dublin Castle, St. Andrew's. Near the Moneague, Dr. Alexander.

F L. July-August.

A low tree: young branchlets bifario-lineated. Leaves an inch and a half long, opposite, subacuminate with the apex blunt, subattenuated at the base, entire, shining, stiff, almost nerveless, very obscurely pellucido-punctulated. Peduncles interpetiolar, for the most part solitary, compressed: pedicels about two lines in length. Calyx with the calyptra adhering on one side till the fruit is perfected. Petals $\bigcirc$. Filaments numerous, capillary : anthers very minute, spherical, ycllow. Style subulate, slightly curv. 
ed : stigma acute. Berry size of a small gooseberry, purple, glaucous, abounding in pulp, 1-seeded: seed small in proportion, size of a coriander seed.

\section{Calyptranthes chytraculia. Bastard Green- heart.}

Leaves elliptic acuminate entire, somewhat stiff glabrous, peduncles at the forking of the branches, as also the flowers, rufo-tomentose.

Chytraculia arborea, foliis ovatis, racemis terminalibus, Browne, 239. t. 37. f. 2.-Calyptranthes chytraculia, Swartz, Fl. Ind. Occ. 921.

H A B. Common, lime-stone hills.

F L. June-August.

A shrubby tree about 12 feet in height: branches round, glabrous, ash-coloured, dichotomous, spreading, towards the extremity slightiy compressed and rufo-tomentose. Leaves opposite, when young partially tomentose on the under surface: petiole terete, when young rufo-tomentose. Peduncles 1-2, frequently $3-4$ at the forking of the branchlets, ferrugineo-tomentose, trichotomous. Flowers small, panicled, subsessile. Opercule of the calyx externally tomentose, ciliated. Filaments numerous, white, deciduous. Style subulate, slightly curved: stigma acute. Berry one-seeded.

This tree is common in the Port Royal Mountains. It delights in a limestone district.

\section{Calyptranthes zuzygium. Axillary flow- ering Calyptranthes.}

Arborescent, leaves ovate obtuse stiff, peduncles axillary trichotomous many-flowered glabrous.

Suzygium fruticosum, foliis ovatis nitidis, Browne, 240. t. 7. f. 2.-Calyptranthes suzygium, $\$$ wartz, Fl. Ind, Occ. 919.

H A B. Limestone districts near the sea-shore. F L. June.

A low tree, 10-12 feet in height. Leaves entire, very glabrous: petioles short, glabrous. Peduncles from the axils of the subterminal leaves, longer than the leaves $\mathrm{tr}$ - 
chotomous, glabrous: pedicels elongated. Flowers larger than those of the preceding species. Calycine opercule glabrous, with a short central point. Filaments long. deciduous: anthers minute. Style subulate: stigma acute. Berry black; seeds 3.4, with one only arriving at maturity.

\section{Eugenia.}

Calycine tube subrotund: limb deeply 4-par1ite. Petals of the same number as the lobes of the calyx. Stamens $\infty$, free. Ovary 2-3-celled; cells many-ovuled. Berry subglobose, crowned with the lobes of the calyx; when ripe 1 , rarely 3-celled: seeds 1 $\mathcal{2}$, roundish, large: embryo pseudocotyledon sus (cotyledons very thick, and cohering); radicle more or less indistinct, very short.-DC.

Named in honor of Prince Eugene of Savoy, a patron of Botany.

\section{* Peduncles axillary, one-flowered.}

1. Eugenia ligustrina. Privet-leaved Eugenia.

Peduncles one-fiowered axillary furnished with a lanceolate bractea at the base ebracteolated beneath the flower, leaves oblong obtuse very glabrous pellucido-punctulated.

Myrtus ligustrina, Swartz, Fl. Ind. Occ. 885-Eugenia ligustrina, Willd. Spec. II. 962.

II A B. Road from Maverly to Bryan's Mountain, St. Andrew's.

F L. March-A pril.

A shrub about 10 feet in height, with spreading branches. Leaves an inch and a half long, and nearly $\frac{1}{2}$ inch in breadth. Flowers white resembling those of the common myrtle, axillary, towards the end of the branches: pedicels half an inch in length: bractea shorter than the pedicel. Calycine segments oval, obtuse. Petals longer than the calyx, obtuse, patent, deciduous. Stamens numerous. Style filiform: stigma acute.

Swartz met with this plant in Hispaniola. The fruit 
according to him, is of the size of a pea, scarlet when ripe, and 1 -seeded. The leaves in my plant were not fragrant.

2. Eugenia balsamica. Balsamic Eugenia.

Pedicels lateral solitary 1-flowered slender subvillous bibracteolated beneath the flower, leaves ovate obtuse acuminate, pale punctulated and glabrous beneath, calyx subvillous. $-D C$.

Myrtus balsamica, Spreng Syst. II. 481.-- Eugenia balsamica, Jacq. fragm. t. 45. f. 2.

H A B. Jamaica?

F L.

The ciliated petals are half the length of the stamens.

\section{Eugenia alpina. Alpine Eugenia.}

Pedicels axillary solitary one-flowered shorter than the leaf rather thick, leaves ovate coriaceous veinless glabrous, branchlets subquaternate erect ferruginous. $-\boldsymbol{D C}$.

Myrtus alpina, Swartz, Fl. Ind. Occ. 883.

II A B. West Peak of the Blue mountain. Swartz.

F $\boldsymbol{L}$. November-December.

A low tree. Leaves very numerous, small, nerveless, stiff like those of the yew, very glabrous, shining, dark green: petioles very short. Peduncles scarcely longer than the petiole. Flowers minute, white. Calycine lobes ovate, obtuse, concave, externally hoary. Petals 4 , larger than the segments of the calyx. Style subulate : stigma acute. Berry 1-seeded, with the seed oblong.

4. Eugenia emarginata. Emarginate-leaved Eugenia.

Peduncles axillary 1-flowered half the length of the leaf solitary, leaves obovate very shortly petiolate subemarginate entire thick coriaceous paler and minutely punctulated on the under surface.

Vol。2. 
II A B. Near the Moneague. Dr. Alexander.

TL. February.

A shrub: branches spreading, of a ferruginous colour, glabrous, slightly rough from minute asperities. Leaves about an inch arid a half long, and rather more than an inch broad, subacute at the base, rounded and usually emarginate at the apex: petioles about $\mathbf{2}$ lines in length. Peduncle an inch in length, minutely appressso-puberulous. Bracteoles early deciduous. Calyx persistent, 4-lobed with the lobes rounded.

\section{Eugenia rotundifolia. Round-leaved Eu- genia.}

Peduncles axillary 1-2-flowered of nearly the same length as the leaf solitary, leaves rounded subsessile crenulated with the crenatures rather obscure coriaceous glabrous minutely punctulated especially beneath.

II A B. St. Ann's. Mr. Purdie.

F L.

A shrub, with branches ferruginous, glabrous. Leaf about an inch in diameter. Peduncle about an inch in length, compressed, bearing 1-2 very shortly-pedicelled flowers. Calyx 4-fid, persistent, rounded. Berry 1celled, 1 -seeded.

This plant resembles the eUgenia CRenulata of Swartz, a native of Hayti. It differs however in the peduncle being scarcely longer than the petiole, whereas in the Jamaica plant it is of the length of the leaf. With this exception the descriptions agree.

* * Flowers axillary subsessile, or fasciculatoglomerated in the axils, and shortly pedun. cled.

6. Eugenia disticha. Distichal Eugenia.

Peduncles axillary branched 3-5 flowered very short, leaves distichal ovato-lanceolate acute glabrous, lateral nerves confluent within the margin, calycine lobes 4 , stigma uncinate $-D C$. 
Myrtus disticha Swartz, Fl. Ind. Occ. 894.-Sims, Bot. Mag. 867.-Lindl. collect. 19.-Eugenia disticha, DC. Prod. III. 274.

II A B. Mountains on the Southside.-Swartz. Near Cold Spring, St. Andrew's.

F L. November.

A shrub about 5 feet in height: branchlets long, simple, horizontally spreading. Leaves distichal, 4 inches long and nearly two broad, elliptico-lanceolate, acuminate, entire, concave beneath, glabrous and shining, subcoriaceous: petiole one-fourth of an inch in length, channelled above. Peduncle axillary, of the same length as the petiole, many-flowered: flowers rather large, showy, white, fragrant, shortly pedicelled, furnished at the insertion with minute brownish scales. Bracteoles 2, minute, scale-like, orbiculate, appressed to the calyx. Sepals 4, in pairs. Petals 4, deciduous, rounded, concave, pellucido-punctulated. Stamens numerous, more than twice the length of the petals: anthers white, oval, cordate. Ovary inferior; style length of the stamens, curved: stigma acute. Berry ovate, red, juicy, sweet : seeds $\boldsymbol{2 - 4}$ : cotyledons cohering.

Swartz informs us, that this plant is known by the name of Wild Coffee, from the resemblance of the fruit to the common coffee berry. The figure of Dr. Lindley is considered accurate.

\section{Eugenia axillaris. Axillary-flowered $\mathbf{E u}$ - genia.}

Peduncles axillary simple or divided at the base shorter at first, afterwards of the same length or longer than the petioles, leaves oval or elliptic subacuminate with the apex obtuse subcoriaceous, nerves more distinct on the upper than on the under surface, shining glabrous.

Myrtus axillaris, Swartz, $\mathrm{Fl}$. Ind. Occ. 001 ?-Eugenia axillaris, Poir. Suppl. III. 126.

II A B. Port Royal mountains.

F L. July-September.

A shrub about 8 feet in height: branches spreading, ash-coloured, glabrous. Leaves ovate or elliptico-ovate, or elliptic, slightly acuminate, rounded at the base, entire, 
coriaceous, indistinctly nerved, very glabrous, deep green and shining above, paler and minutely punctulated beneath; the larger leaves nearly 3 inches long, and $1 \frac{1}{2}$ broad: petiole one-third of an inch in length. Racemes axillary, usually shorter, though occasionally longer than the petiole, simple, rarely divided into 2 or 3 branches, many-flowered: peduncle coloured. Flowers 10-20, shortly pedicelled, small, white, each furnished at the base with a minute ovate bluntisn bractea. Calyx minutely bi-bracteolated, 4-partite: lobes rounded, minutely puberulous and ciliated. Petals 4, obtuse, concave, glanduloso-punctulated. Stamens numerous. Style thick, slightly curved: stigma acute. Berry globose, crowned, black, juicy, 1-seeded.

The leaves are smaller in the high mountains and in exposed situations.

\section{Eugenia filiformis. Slender-pedicelled Eugenia.}

Peduncles axillary much shorter than the petiole few-flowered sometime awanting, pedicels delicately filiform, in the absence of the peduncle lateral or supra-axillary, bracteoles oblong subacute, calycine lobes acute, leaves ovato-lanceolate attenuato-acuminate with the apex blunt very glabrous shining above.

II A B. Below Trafalgar, Port Royal mountains.

F L. August.

A shrub about six feet in height: branches fastigiate. Leaves two inches or more in length, almost nerveless, pellucido-punctulated: petiole one-third of an inch in length. Racemules few-flowered: peduncle when present not more than two lines in length; sometimes awanting: pedicels nearly half an inch in lengt'n, filiform, 1flowered, furnished at the insertion with a minute ovate concave brac'ea. Bracteoles a pair immediately beneath the flower, minute, oblong, subacuminate. Sepals subequal. Petals? Stamens numerous.

9. Eugenia buxifolia. Box-leaved Eugenia. Peduncles axillary many-flowered very short, 
leaves obovate wedge-shaped at the base punctulated beneath with the margin revolute, branches and leaves glabrous.

Myrtus buxifolia, Swartz, Fl. Ind. Occ. 899.-Eugenia buxifolia, DC. Prod. III, 275.

H A B. Port Royal mountains, common.

P L. June.

A shrub 6-10 feet in height: branches erect, stiff, ashcoloured, glabrous. Leaves about an inch in length, rounded at the apex, stiff, obscurely nerved and veined, glabrous, shining, paler and punctulated beneath : petiole very short. Peduncles axillary, very short, of the same length as the petiole, bearing about 6 subsessile flowers, each with a bracteated scale at the base. Calyx minute, with the lobes in pairs. Petals twice the length of the lobes of the calyx, ovate, concave, glanduloso-punctulated. Filaments numerous capillary, giving to the flowers a shaggy appearance, white: anthers yellow. Style subulate, curved, persistent: stigma acute. Berry minute subrotund, 1 -seeded. Seed very small.

\section{Eugenia monticola. Mountain Eugenia.}

Peduncles many-flowered very short, leaves ovate or oval bluntish wedge-shaped and revolute at the base opake glabrous.

Myrtus monticola, Swartz, Fl. Ind. Occ. 898.- Eugenia monticola, DC. Prod. III, 275.

II A B. Road from Guanaboa to Spring-Garden, St. John's. Common, Port Royal mountains.

F L. July-October.

A shrubby tree, 6-12 feet in height: branches numerous, fastigiate, erect. Leaves oval, obtuse, entire, coriaceous, obscurely nerved, minutely pellucido-punctulated, about an inch in length, and three-fourths of an inch in breadth: petiole very short, minutely puberulous. Racemes very short, 6-8-flowered: flowers small, white with a crimson tinge, shortly pedicelled, each furnished at the insertion with a minute oblong blunt bractea. A pair of minute bracteoles appressed to the base of the calyx. Calycine segments subunequal, rounded. Petals rather larger than the lobes of the calyx, rounded, concave, glanduloso-punctulated, very minutely ciliated. 
Stamens numerous: anthers didymous with a minute glandule in the division separating the cells. Style slightly curved, longer than the stamens : stigma acute. Berry size of a small pea, subrotund, of a red colour, one-seeded. Seed subrotund, smooth.

The leaves of this species resemble those of our Jamaica Whortle-berry vaccivium meridionale. The flowers are the smallest of our West India species. The above description differs from that of $\mathrm{Swartz}$, in respect to the calyx according to thut Botanist being 4-5-partite and the segments acute, and the petals being 4-5, and of an ovate figure.

11. Eugenia glabrata. Glabrous Eugenia.

Peluncles axiliary subsolitary of the same length as the petiole, flowers minute crowded, leaves lanceolato-elliptic or elliptic wedge-shaped at the base subacuminate with the apex rounded delicately nerved with the lateral nerves confluent near the margin, shining above glabrous beneath.

Myrtus glabrata,Swartz, Fl. Ind. Occ. 903.-DC. Prod. III. 274.

II A B. St. Andrew and Port Royal mountains. Fairfield, Manchester.

F L. June-August.

A shrub about 6 feet in height: branches virgultose, erect, glabrous. Leaves shortly petiolate, $1 \frac{1}{2}-2$ inches in length, and nearly one in breadth: petiole about 2 lines in length. Flowers numerous, small, white, crowded, on very short filiform pedicels, furnished with a minute ovate bractea at the insertion. Bracteoles 2, minute, ovalisubrotund. Calycine lobes rounded, very minutely ciliated, glanduloso-punctulated. Filaments capillary: anthers cordate. Style slightly curved. Berry size of a black currant, usually 2-celled : seeds hemispherical.

\section{Eugenia Wallenii. Wallen's Eugenia.}

Peduncles axillary usually 4 -flowered shorter than the leaves simple minutely ferrugineo-to- 
mentulose, calycine lobe: and bractea acute, leaves ovato-lanceolate attenuato-acuminate shining sparingly puberulous.

II A B. Cold-Spring, and Wallenford.

P L. August-October.

A shrubby tree, about 12 feet in height : branches fastigiate, virgultose, slender, slightly compressed at the end, ferrugineo-tomentose. Leaves stiff, shining, bluntish, with an apicula, minutely puberulous especially along the under surface of the mid-rib, obscurely nerved with the nerves anastomosing near the margin, entire, 2 inches in length and scarcely more than half an inch in breadth: petiole short. Flowers strall, white, fragrant. Peduncle about half an inch in length, sub-4-agonal, ferrugineopuberulous : pedicels the two lower ones usually opposite, filiform, each furnished at the insertion with a minute ovate acute bractea. Bracteoles a pair, ovate, apiculato-acuminate, appressed to the calyx. Calycine lobes 4: the two outer opposite, rather smaller, lounded, acuminatoapiculated: the 2 inner rounded; externally ferrugineopuberulous, ciliated. Petals 4, roundish, concave, minutely ciliated, glanduloso-punctulated. Stamens numerous. Style subulate.

I have dedicated this plant to the memory of the late Matthew Wallen, Esquire, the friend of Swartz, and formerly the owner of the properties on which this plant was found.

*** Peduncles axillary bifid or dichotomous with the flowers in the fork sessile, and the others pedicelled.

\section{Eugenia dichotoma. Dichotomous Eu- genia.}

Peduncles axillary opposite and subterminal length of the leaves bifid or twice bifid with a sessile flower at each bifurcation and the rest pedicelled, leaves elliptico-lanceolate pellucido-punctulated, the young branchlets peduncles and petioles pubescent.

DC. Prod. III. 278. 
II A B. Port Royal Mountains, Bridge-hill and Bellvue woods.

F L, May.

A tree, about 15 feet in height: branches compressed, minutely puberulous. Leaves about an inch and a half in length, and nearly one in breadth, elliptic, subacuminate with the apex blunt, attenuated at the base, subentire, glabrous, shining above: petiole about 2 lines in length, puberulous. Peduncles axillary, about the length of the leaf, compressed, dichotomous with a sessile flower at the bifurcation: pedicels terete, previous to the opening of the flower sericeo-pubescent. Bracteoles appressed to the calyx, oblong, foliaceous. Calycine lobes obtuse, ciliated, glanduloso-punctulated. Stamens numerous: fila. ments delicatelv capillary. Style ereot, declinate. Fruit globular, size of a pea, 2-3-celled.

This description differs from the characters given by DeCandolle.

\section{Eugenia bracteata. Bracteated Eugenia.}

Peduncles axillary and subterminal longer than twice the length of the leaf dichotomously branched with a sessile flower at the bifurcation and with the lateral flowers pedicelled, berry bilocular with the locules 2-3-seeded, leaves elliptic very shortly acuminate, subacute at the base, glabrous entire, petiole short puberulous.

H A B. Port Royal mountains.

F L. July.

A low tree: branches terete, rough, ferruginous, to. wards the end compressed and minutely puberulous. Leaves decussating, dark green above, paler and pellucido-punctate beneath; with the nerves indistinct and parallel: petiole slightly channelled. Peduncle twice the length of the leaf, with the branches divaricating compressed and minutely puberulous. Flowers white, fragrant, with a pair of bracteæ at each division of the peduncle, and a pair of bracteoles to each flower: bracteoles oblongo-lanceolate, puberulous. Calycine divisions 4, ovate, concave, blunt, puberulous. Petals 4, roundish, concave. Stamens very numerous, about twice the length of the petals. Style declinatc, and curved. Berry 2. 
celled : cells 2 -seeded.

To the taste, the leaves are acrid with an aromatic warmth. This plant is evidently nearly related to the preceding.

15. Eugenia fragrans. Fragrant Eugenia.

Peduncles axillary dichotomously branched with a sessile flower at the bifurcation twice the length of the leaf, leaves elliptic rounded or subacuminate at the apex shining above slightly concave and punctulated beneath, arboreous.

Myrtus fragrans, Swartz, $\mathrm{Fl}$. Ind. Occ. 914 ?

II A B. Port Royal mountains. Road from GreenValley to Old England.

F L.

A tree about 50 feet in height: stem straight, smooth: branches towards the end subtetragonal, compressed, puberulous, glanduloso-punctulated. Leaves decussating, rounded, retuse, or subacuminate with a blunt point at the apex, entire, obscurely veined : petiole short. Peduncles solitary. Bracteæ linear, appressed. Flowers size of those of the common myrtle, white, very fragrant, shortly pedicelled, with a pair of linear bracteoles appressed to the calyx. Calycine lobes 4, concave: the two outer subacute; the two inner rounded. Petals rotundo-ovate, concave, spreading, white, glandulosopunctulated, deciduous. Stamens numerous. Style subulate, deslinate : stigma acute. Berry globular, 1 -seeded.

This forms a very beautiful tree. It is remarkable for its straight erect stem, sending off no branches until it has attained a considerable height. It may be mistaken for the mountain guava, from the resemblance of the stem, the bark of which, as also that of the Pimento, is remarkably smooth and of a grey ferruginous colour.-The above description differs so much from that of Swartz, that the identity of the plants may be doubted.

**** Peduncles racemoso-cymose panicled, axillary or terminal.

16. Eugenia virgata. Rod-Wood.

Racemes axillary and terminal shorter than

Vot. 2.

$\mathrm{H} *$ 
the leaf, leaves oblorgo-ovate acuminate with the apex sharp acute at the base sparingly pubescent shining above pellucido-punctulated submembranaceous.

'H A B. Port Royal Mountains.

F L. June.

A shrubby tree, about 12 feet in height: branches virgate dichotomously divided, slightly compressed, of a ferruginous colour, when young villoso-pubescent. Leaves subdistichal, entire, concave beneath, obliquely nerved, shining above, minutely puberulous especially along the under surface of the nuid-rib, pellueido-punctulated, submembranaceous, 3 inches long, and $1 \frac{1}{4}$ broad: petiole short, slightly channelled, pubescent. Racemes simple, axillary and terminal, usually 2 , sometimes 3 together, more than twice the length of the petiole, 8-12-flowered: pedicels single or two together, half an inch in length, puberulous, one-flowered, furnished at the base with a small lanceolate ovate acute bractea. A pair of minute ciliated appressed bracteoles at the base of the calyx. Calycine segments subequal, rounded, concave. Petals 4, rounded, concave, glanduloso-punctulated. Stamens numerous. Style erect: stigma simple.

In this species the branches are decidedly virgate. This shrubby tree is very common in the Port Royal mountains, and is known commonly by the name of the Rod-Wood.

\section{Eugenia virgultosa. Wand-like Eugenia.}

Racemes axillary and terminal shorter than the leaf, leaves lato-lanceolate attenuato-acuminate obtuse glabrous shining pellucido-punctulated, berry 2-3-seeded.

Myrtus virgultosa, Swartz, Fl. Ind. Occ. 905.

II A B. Common, higher mountains.

F L. May-June. August, Swartz.

A shrubby tree, 6-10 feet in height: branches glabrous. Leaves decussating, $2 \frac{1}{2}$ inches long, and 1 broad, subentire or obsoletely crenulated, coriaceous : petiole terete very minutely puberulous. Racemes usually simple, and solitary: peduncle subtetragonal, pubescent: pedicels 
half an inch in length, opposite, terete, puberulous, each furnished at the insertion with a small ovate bractea. A pair of minute broad-ovate ciliated bracteoles below the calyx. Flowers numerous; showy, white, tinged with rose colour. Calyx minute, externally puberulous, 4cleft: divisions sub-equal, rounded, spreading. Petals obovate, rounded, minutely concave, glanduloso-punctulated. Stamens longer than the petals. Style erect, longer than the stamens. Berry spherical, purple, rather dry, erowned with the calycine segments, 2-3-seeded. Seeds hemispherical.

The terminal racemes are usually as long as the leaves and are fasciculato-panicled. The petals are very deciduous, and disappear after a shower of rain. The tree is a very beautiful object when in flower.

\section{Eugenia acutiloba. Sharp-lobed Eugenia.}

Racemes axillary 7 -flowered shorter than the Ieaf simple, peduncle and its divisions subhirsute, bracter and calycine lobes acute, leaves ovalioblong attenuated at the base acuminate pellucido-punctate, the upper surface when young subvillose, when old glabrous impunctate, the under surface pale pubescenti-villous. $-D C$.

DC. Prod. III. 281.

H A B. Port Royal mountains.

F L. July.

A shrubby tree, about 12 feet in height: slightly compressed, glabrous, of a ferruginous colour. Leaves oblong, acute at the base, attenuato-acuminate with the apex sharp, nerved, pellucido-punctate; when young slightly villous, when old glabrous on the upper surface ; pubescenti-villous with appressed hairs beneath. Racemes 7-9 flowered : flowers opposite, pedicelled, each furnished with an appressed bractea at the insertion: Bracteoles 2, ovate, acute. Calyx externally ferrugineo-villous: divisions acute.

19. Eugenia dumosa. Savannah Eugenia.

Racemes axillary and subterminal shorter than 
the leaf, leaves ovate bluntly acuminate glabrous shining pellucido-punctulated, berry one-seeded.

II $\perp$ B. Thickets, Liguanea.

F L. April.

A șhrub, 6-8 feet in height: branches erect, virgate, terete, towards the extremity minutely puberulous. Leaves about two inches in length: petiole puberulous Racemes few-flowered: peduncle of the same length as the petiole: pedicels about 3 lines in length, each furnished at the base with an ovate puberulous bractea: brac. teoles 2, minute, acute, at the base of the calyx. Flowers white with a crimson tinge. Sepals subequal, rounded. Petals 4, rounded, minutely ciliated. Berry size of a large pea, scarlet, one-seeded : seed subglobose.

\section{Eugenia Chrysophylloides. Star-apple- leaved Eugenia.}

Panicles towards the end of the branches axillary and terminal 2-3 together shorter than the leaves, poduncle dichotomously branched, divisions compressed ferrugineo-pubescent, with a sessile flower frequently at the bifurcation but with the others pedicelled, calycine lobes unequal, leaves elliptico-lanceolate obtuse pellucidopunctulated, berry oblong.

\section{A B. Salt-Hill, Port-Royal.}

F L. October.

A shrubby tree, 10-15 feet in height: branches at the end compressed and ferruginous. Leaves acuminate with the apex blunt; at the base acute and somewhat revolute, entire, shining, glabrous except being puberulous along the under surface of the nerves, diagonally nerved, 34 inches long and $1 \frac{1}{2}$ broad: petiole terete, channelled. Panicles solitary or 2-3, axilliry and terminal, seldom more than 2 inches in length: peduncles angulose, ferrugineo-pubescent, irregular!y branched. Flowers rather large, white, shortly pedicelled. Bracteoles 2, minute, ovate. Calyx externally ferrugineo-puberulous with the lobes ciliated: the 2 outer ones rounded; the 2 iriner ovate and smaller. Petals 4, rounded, ciliated, oleosopunctulated. Sityle declinate, villous at the base. Berry 
oblong, red, one-seeded : secd oblong.

The specific designation has been suggested by the resemblance to the leaves of the Star-apple, although the beautiful rufous pubescence on the under surface is wanting.

\section{Eugenia Pimenta. Pimento-berry.}

Peduncles axillary and terminal 3-chotomously panicled, flowers in the bifurcation subsessile, the others pedicelled, leaves ob!ong pellucido-punctulated subopaque glabrous, branchlets compressed or sub-3-gonal, when young puberulons.

Myrtus arborea aromatica, Sloane, II. 76. t. 191. f. 1. -M. foliis oblongo-ovatis, Browne. 247-Myrtus Pimenta, Swartz, Ubs. 202.-Sims. Bot. Mag. t. 1236.-Eugenia Pimenta, DC. Prod. III. 285.

II A B. Common, particularly in limestone districts. I L. March-May.

A tree, $\mathbf{3 0 - 4 0}$ feet in height: stem straight, erect, with a smooth ash-coloured bark: branches towards the end compressed, subtetragonal, or sub-trigonal, and when young minutely puberulous. Leaves opposite, rarely in threes, 5 or more inches long, and $1 \frac{1}{2}$ broad, obtuse, diagonally nerved: petiole short. Panicles shorter than the leaves, many-flowered: peduncle compressed, minutely puberulous: branches decussating, with the terminal subdivision 3 -flowered with the one at the bifurcation sessile, and the lateral ones pedicelled. Bracter leaf-like, deciduous : bracteoles 2, very minute, persistent. Calycine lobes subequal. Petals larger than the calyx, horizontally spreading, concave, oleoso punctulated. Stamens numerous. Style erect, puberulous: stigma obtuse. Berry globular, size of a red currant, purple, juicy, one-seeded.

There is a difference of opinion respecting the trees which are known as male. They are supposed by $\mathrm{Pi}$ mento-planters to be necessary to ensure a crop, and it would be regarded as an act of insanity to cut them down. This is one of many popular errors. The flowers of the fruit bearing trees are always found to be hermaphrodite, with perfect stamens and pistil. There was a solitary tree at the Bath Garden, many miles distant from any other of its species; and, notwithstanding this, it annu- 
ally produced an abundant crop. The flowers of the barren trees, differ in nothing from those of the fertile, except that they are somewhat smuller, and that the stamens are more fully developed, and more numerous, whereas the different parts of the pistil are smaller. The circumstance therefore of certain trees being barren must be referred to some peculiarity in the system, incapacitating for the due performance of the reproductive function. Pimento-growers inform us that this may be remedied, and that by cutting and pruning close for two or three years, such trees may be rendered fertile.

The Pimento is a common tree in several districts of this Island, more particularly in the parish of St. Ann; and in hilly parts where the white limestone prevails. The birds are very fond of the berries when ripe, and thus become active agents in disseminating the tree. Hence in a district where Pimento is grown, in order to establish a Walk or Plantation, it is only necessary to clear the trees and brush wood from a piece of land, when young Pimento plants will spring up in every direction. Very little care, with the exception of an occasional cleaning, is required, and in a few years, what has received the name of a Pimento-Walk, is established.

The crop is collected during the months of June, July, and August, by breaking off, with the hand, the branches, bearing fruit. It is said that the trees suffer less if the branches are broken, than if they are removed by cutting or pruning with a sharp instrument. The berries are taken bəfore they ripen, when they are still green, and are dried on barbicues by exposure to the sun. When thoroughly dry, they are put into bags, each containing a hundred pounds. The ripe berries, I may mention, are rejected; for when dry they are almost tasteless and possess very little of the peculiar aromatic flavour.

Pimento plantations, in productive years, are a source of great wealth to their proprietors. A single tree has been known to yield one hundred and fifty pounds of cured Pimento. The crop, however, is very uncertain ; for the trees seldom bear heavily oftener than once in five years.

Pimento has received the name of Jamaica pepper; from the circumstance that the supply is almost wholly furnished by this Island. The name of Allspice has been given to it because its flavour was considered to be a 
combination of those of Cinnamon, Nutmeg, and Cloves. It is principally employed as a condiment in cookery. In medicine it ranks as a warm stomachic carminative. 'The dose of the powder is from five grains to a scruple. 'I'he essential oil and the distilled water, also hold a place in the Pharmacopeia. The latter is selected as a vehicle for purgative medicines, especially rhubarb, the nauseous taste of which, to a certain degree, it conceals.

\section{Grias.}

Calycine tube adhering to the ovary; $\operatorname{limb}$ small, 4-cleft, obtuse. Petals 4, coriaceous. Stamens $\infty$, inserted on a 4-sided disk : filaments at the base connate in five rows, the inner ones being the shortest: anthers reniform, minute. Style O: stigma cruciform concealed by the incurved stamens. Drupe ovate, 8-sulcated, crowned with the calyx, with the nut oblong.-DC.

Name from youv comedo to eat, in allusion to the edible quality of the fruit.

\section{Grias cauliflora. Anchovy-Pear.}

Palmis affinis Malus Persica maxima, caudice non ramoso, foliis longissimis, fructu ex arboris trunco, Sloane, III. 123. t. 217.-Calophyllum foliis tripedalibus obovatis, floribus per caulem et ramos sparsis, Browne, 245-Grias cauliflora Linn. Sp. Pl. 732._Suartz, Obs. 215.

H A B. Wet marshy situations. Near Port-Morant. F L. Spring.

A tree 30-50 feet in height: branches undivided or none. Leaves shortly petiolate, $3-3 \frac{1}{2}$ feet in length and about 10 inches in breadth at the broadest part, obovato-lanceolate, acuminate, wedge-shaped at the base, being continued along the petiole till within an inch and a half or two inches of the insertion; surface glabrous, of a dark green, and nerved; margin entire and subundulated. The flowers are large, white, fragrant, produced from the stem: peduncles very short, many-flowered: pedicels short, crowded, one-flowered. Calyx 4-cleft. 
Petals 4, oblong, obtuse, thick, concave. Fruit has been compared in size to the Alligator's egg, and also to the fruit of the Mammee-Sapota.

This tree is usually found in clumps or thickets, from the seeds growing readily in damp situations, and from a number of the plants, springing up where the seeds have dropt and hence becoming established in the locality. I cannot discover why the name Anchovy should be applied to the fruit of this Tree, unless it be to establish the assertion, that Anchovies may grow on trees. Though it is a common tree in certain districts, I cannot learn that the fruit is ever collected for use, or brought to market.

\section{ORDER. LXXX. CUCURBITACEE- THE CUCUMBER FAMILY.}

Flowers hermaphrodite, monœcious or diœcious. Calyx 5-toothed, sometimes obsolete. Petals 5, distinct or more or less united, sometimes scarcely distinguishable from the calyx, strongly marked with reticulated veins, sometimes fringed. Stamens 5, distinct or united into 1-3 parcels, attached to the petals: arthers bilocular, sinuous. Ovary adhering to the tube of the calyx, 1-celled, with three parietal placentæe, which often project and uniting form a central column : style short : stigmata thick, velvety or fringed. Fruit more or less succulent, crowned with the scar of the calyx : seeds flat, ovate, enveloped in a juicy or dry and membranous covering: testa coriaceous: albumen $O$ : embryo straight: cotyledons leafy : radicle next the hilum.

\section{Fevillea.}

Flowers diøecious. $\approx$ Calyx 5-cleft beyond the middle. Petals 5, subcoalescing at the base, 
inserted on the throat of the calyx, alternating with the sepals. Stamens 5, inserted with the petals, alternating with them, sometimes 10 , with every alternate one sterile: anthers 2-celled, didymous. \& Calycine tube adnate to the ovary ; limb 5-cleft. Petals 5, distinct (or united at the base), oblong. Lamellæ (abortive stamens) 5. Styles 3, with stigmata broad, obtusely bifid. Fruit globose, fleshy, marked in the centre with a circular line (indicating where the calyx adhered) and with 5 cicatrices, internally 3 -celled : indehiscent, with the rind solid, and with the central axis large fleshy and 3 -gonal : cells manyovuled. Seeds compressed, oval, exalbuminose : embryo straight, with cotyledons plane, subcarnose. $-D C$.

Named in honor of Lewis Fevillée, a French Franciscan monk who travelled in Peru.

\section{Fevillea cordifolia. Antidote Cocoon,}

Leaves cordate acuminate undivided or pentangulo-sublobate with four of the angles glanduloso-incrassated.

Ghandiroba vel nhandiroba Brasiliensibus, Sloane, I. 200. Fevillea foliis crissioribus glabris quandoque cordatis, quandoque trilobis, Browne, 317-F. scandens, Wright's Memoirs, 211-F. cordifolia, Swartz, Obs. 377.

II A B. Common in damp wooded valleys, and shady places.

F L. A pril-June.

Stem perennial, climbing to a great height. The early leaves are undivided, whereas those towards the end of the brarches are pentangulo-lobate, with the four central angles glanduloso incrassated; otherwise eglandulose; nerves three with the lateral nerves bifurcated near their origin; texture thick, glabrous, porose. $\delta$ Racemes axillary and terminal, subdivided: peduncle angular, puberulous with capitate hairs. Flowers rather small, of

VoL. 2. 
a dusky orange. Calycine lobes oblong, obtuse, puberulous. Petals 5, obovato-rotund, slightly clawed, puberulous with minute capitate hairs, alternating with the divisions of the calyx. Lamellæ sickle-shaped, attached to the petals as far the centre of the limb, then curved over the anthers. Stamens 5, connected, at the base, corresponding and opposite to the petals: filaments pellucid, bearing the anthers on the under surface, of their club. shaped termination. \& Flowers solitary, axillary, shortly peduncled. Calyx, petals, and lamellæ as in the male flowers. Styles 3 : stigmata subreniform. Fruit globose, size of an apple, of a russet colour, hard, many-seeded : seeds large, orbicular, flattened, scabrous.

Barham, an old writer on the plants of Jamaica, mentions that he found this plant in that part of St. Thomas in the Vale which was known in his time by the name of the Sixteen-mile-Walk. The fruit, he adds, is like a green calabash, only it has a circular black line round it, and two or three warts or little knobs. The inside of the shell is full of white flattish beans, inclosed in a white membranaceous substance. The nuts or beans are full of oil, and excessively bitter. They are ten or twelve in number, and are so close and compressed, that when 1 liave taken them out, I never could place them so again, as to make the shell contain them."

It has often been remarked, that when any vegetable production is more than usually nauseous and unpleasant to the taste, popular opinion immediately concludes that it must pos ess medicinal properties. This is, I believe, the case with the Antidote Cacoon, which has, for no good or sufficient reason, been established in the domestic Pharmacopeia of the West Indies as a most valuable plant. It has been regarded also with favor by the French Colo. nists, having received from them the names of "Liane cuntre-poison," and "Liane epileptique." The Spanish physicians we are to!d, employ it with success, in the form of emulsion, for intermittert fever, and as a counter-poison. The Bucaniers esteemed it so highly, that they never ventured on an expedition without taking with them a supply of this fruit (Poupée Desportes III. 54).

Of the medicinal properties of these seeds I cannot speak from my own experience. Dr. William Wright in his Memoirs states, "I am far from agreeing that it is of use for pains or weakness of the stomach. On the contrary I find the disorder rapidly to advance under its use, 
and that the patient gets into a dropsy." As, in a full dose, vomiting and purging are produced, it may be from this quality that it has acquired its reputation as an alexipharmic.

In some families it is kept infused in spirit, with orange peel and wild cinnamon, and a portion of this tincture diluted with wine is not unfrequently offered to the guests previous to dinner. This is a most abominable potion, to be relished only by the most devoted dram-drinker, and calculated to bring on nausea and loss of appetite; a most serious occurrence at such a time. It reminds one of the liqueur known by the name absinthe, but surpasses it in every unpalatable quality.

The seeds abounding in oil, burn freely when ignited, and serve as a substitute for candles. The expressed oil gives a clear light when burnt in lamps, and has been manufactured into candles.

In cases of poisoned wound, such as that by a dog suspected of rabies, the pounded kernel of the seed, mixed with laudanum, is applied to the wound, and the application is regarded, by the simple natives, as the "sovereign'st thing on earth ;" whereas the only effect that can be produced is that of irritating the wound.

\section{Lagenaria.}

Calyx campanulate; lobes subulate or somewhat broad, shorter than the tube. Corolla white: petals obovate, arising within the margin of the calyx. of Stamens 5, tri-adelphous with the fifth free. \& Style generally 0 : stigmata 3, thick, bilobed, granulose. Fruit 3-5?-celled: seeds obovate, compressed, tumid at the edge, bilobed at the apex.

Name from LAGENa $a$ bottle.

\section{Lagenaria vulgaris. Bottle-Gourd.}

Softly pubescent musky, stem scandent, cirrhi 3-4-cleft, leaves cordate subentire piloso-subglaucescent biglandulose at the base, flowers monœcious stellated very patent fasciculed, connective 
with oblongo-ovate acute papillæ, fruit pubescent, when ripe glabrous very smooth with the pulp white and edible. $-\boldsymbol{D C}$.

Cucurbita tertia seu lagenaria, flore albo, folio molli, Sloane, I. 225.-C. villoso, fructu pyriformi, Browne, 354.

II A B. Fences and waste places.

F L. Throughout the year.

Fruit is of various shapes and sizes. Some are six feet long and two feet thick. The large gourd resembles a bottle in shape having a long neck and large bulb, and when freed of its pulp and seeds will hold several gallons of water. Some are cylindrical, and serve as powder horns. The African negroes also make of it a musical instrument, resembling a guitar, styled the Banjo, to produce an accompaniment to their simple songs. The pulp is never employed for any purpose. A decoction of the leaves is said to be purgative. The fruit is styled by the French "Calabasse rampante ou de terre"

\section{Cucumis.}

Calyx tubuloso-campanulate; divisions subulate scarcely the length of the tube. Petals slightly united among themselves and to the calyx. of Stamens 5, triade! phous. \& Stigmata 3, thick, bipartite. Pépo 3-6-celled, with the seeds ovate, compressed and not margined.

Name from the Latin cuccurs, a cucumber.

\section{Cucumis melo. The Melon.}

Stem humifuse scabrous cirrhiferous, leaves rounded angular; Male flowers, with the tube of the calyx subventricose at the base dilated at the apex, stamens included, and anthers shorter than the connective; hermaplirodite flowers, with the anthers as in the former, the stigmata $3-4$, shortly bi-lobed ; fruit ovate or subglobose 8-12-sulcated, with the flesh yellow or white- $-D C$. 


\section{H A B. Cultivated.}

\section{F L. After the May and October ra.ns.}

The Musk-Melon thrives best in dry districts, and in a good soil. In such situations it comes to great perfection, requiring very little cultivation. It is supposed to have been originally a native of Asia, and to have been cultivated from time immemorial.

The flesh of the Melon, when ripe, and of a good description, is cooling and refreshing, and promotes the evacuations. The pulp is applied externally as a cooling application to inflamed surfaces. There are souie, whose digestion is impaired, with whom this fruit does not agree. They find it heavy, indigestible, and occasionally apt to excite fever. 'This is owing either to a peculiar idiosyncrasy, or to the bad quality of the fruit. It usually proves grateful to the taste, and easily digested. To obviate the apprehended bad effects, some eat the fruit with salt: whereas others sprinkle it with sugar, thus giving "sweets to the sweet." I may add that an emulsion may be prepared from the recent seeds, which is considered to be soothing and pectoral.

\section{Cucumis sativus. Cucumber.}

Stem scabrous cirrhiferous, leaves cordate obscurely 5-lobed, flowers shortly peduncled subternate rather large, tube of the calyx tubulosocampanulate, limb patent deflected, petals somewhat acute, fruit oblong triquetrous.

H A B. Cultivated.

F L. Throughout the year.

This species also came originally from Asia. The fruit is either used crude as a sallad, or it is boiled and added to stews. In the crude state it is found to be cooling and laxative. It is sometimes preserved in salt, with the addition of spices. Cucumbers prepared in this manner are imported into England from Russia, and occasionally find their way to Jamaica.

\section{Cucumis anguria. Wild Cucumber.}

Very hirsute, stem humifuse angulated cirrhiferous, lcaves cordate palmato-sinuated 3-4-or-5- 
lobed with the lobes subentire, $\delta$ flowers subsolitary, fruit ovoideo-globose echinated.

C. anguiræ, folio latiore aspero, fructu minore candido, spinulis obtusis muricato, Sloane, Jam. 105-C. subhirsutus minor, Browne, 335-C. sylvestris Americanus, fructu ovi figura. Pluk. Phyt. 170. f. 3.-C. anguria. Linn. Sp. 1436.

II A B. Common in dry pastures.

F L. 'Throughout the year.

Stem pentangular, longitudinally sulcated, scabrosohirsute, thickness of a crow quill. Leaves 3-lobed, (the middle lobe the largest, and the lateral lobes sub-bilobed) hirsute with very stiff hairs, denticulated except towards the base where the margin is subentire: petiole longer than the leaf, longitudinally channelled. Cirrhi simple, solitary, arising from the side of the petiole Male flower small, yellow: peduncle axillary, subsolitary, sometimes accompanied by a female flower, about one-third of an inch in length, filiform, hispidulous. Calycine segments alternating with the divisions of the corolla. Segments of the corolla rounded, veined, externally hispidulous. Stamens 3-adelphous: filaments short: connective produced beyond the anthers. Rudiments of the ovary a spherical depressed disk. Female flowers on a peduncle at first an inch in length, but elongating as the fruit ripens Ovary echinated: style received into an annular disk: stigmata 3, oblong, with the inner surface smooth, and the outer granular.

This is a very wholesome vegetable, dressed plain, or in stews. It is also esteemed as a pickle.

\section{Cucumis Citrullus. Water Melon.}

Very pilose, stem humifuse cirrhiferous, leaves obtusely pinnatisected sub-glaucescent, flowers solitary unibracteated, bractea oblong, fruit subglobose glabrous stellato-maculated.

Anguria prima, citrullus dicta. Sloane, I. 226.-Cucurbita citrullus. Linn. Sp. 1435.-Cucumis citrullus, DC. Prod. III. 301.

H A B. Cultivated.

F L. Throughout the year. 
This plant is regarded as originally a native of Africa and India. It is also cultivated in the Levant, Italy and the South of France, and in the warmer regions of the American continent, as well as in these Islands. It has been remarked that it thrives best in maritime situations, as if the sea air were favorable to its growth and productiveness. In this island it acquires the greatest perfection, and no particular cultivation is required. The fruit is not unfrequently a foot and a half in length, with the diameter in proportion. As a proof of its abundance, I may mention that the price varies from three-pence to six. pence.

The pulp is of a red colour with its cells filled with a watery fluid, so that it dissolves nearly entirely in the mouth. From this quality, it has received the name of Water Melon. It is a most grateful fruit to the inhabitants of warm countries, superior in its cooling effects, as well in being grateful to the palate, to any of the ices or other highly-prized preparations of the most skilful confectioner. At the same time it is light of digestion, agreeing with the weakest stomachs, and yielding though sparingly a certain degree of nutriment. The fruit even when removed from the stem, after being exposed for some time to the mid day sun, is still found to be cool and refreshing. I have given it with advantage in fever. It is slightly laxative. The French have bestowed on the seeds of the Melons, the name of "semences froides" and have employed them in the form of emulsion, in the treatment of inflammatory fevers. By the Arabian physicians they are regarded as lithoritriptic.

\section{Luffa.}

Male flowers panicled, yellow. Tube of the calyx hemispherical; the divisions longer than the tube. Petals free, deciduous. Stamens 5, free; anthers very flexuose. Female flowers solitary. Calyx with the tube oblongo-clavate; divisions shorter than the tube. Stamens subabortive. Stigmata reniform. Pepo ovate 3locular.

Name derived from louff, the Arabic name of LuFfa RGYPTIACA. 


\section{Luffa acutangula. East-Indian-Okra.}

Stem tortile, leaves cordate subquinque-lobate acutely toothed, cirrhi undivided or 2-3-cleft, fruit clavate 10-angular crowned at the apex with the calyx, rind hard, seeds plane oblongo-rotundate black and shining when ripe.

II A B. Cultivated. On fences.

F L. Throughout the year.

It is probable that this plant was brought here by the Coolie emigrants, as it is of very recent introduction. It is a native of the East Indies, where it is much esteemed as a pot-herb. It is very generally cultivated in the Isles of France and of Bourbon.

\section{Luffa Egyptiaca. The Strainer Vine.}

Stem hirsute anguloso-sulcated, leaves cordate subrotund lobed with the lobes angular excised at the base with the margin incumbent, cirrhi simple, fruit obovato-clavate 10-angled crowned with the divisions of the calyx.

Cucumis $\mathbb{E} g y$ pticus reticulatus, Moris. Hist. I. 35. f. 1. t. 7.-Momordica luffa, Willd. Spec. IV. 603.-Luffa Egyptiaca, DC. Prod. 303.

II A B. Fences.

F L. Throughout the year.

The specimens of the fruit that I have met with resemble in shape and size the common cucumber, being however somewhat thicker. The attachment of the fruit to the vine continues after the fruit has become ripe, and the pulp has decayed, so that only the reticulated fibres are left, preserving the form or frame-work, and representing as it were the skeleton of the fruit. In this state, it is adapted and has been applied to the purpose of straining limejuice for the manufacturing of Punch. Hence it has received the familiar designation of the Strainer-Vine. Those who resort to this expedient, however, must be more curious than particular, as the process by this method would be very imperfectly performed.

The pulp, though insipid, is said to constitute an article 
of food among the Egyptians. It is also rubbed over the surface of the body, after the bath, to act as a cosmetic.

\section{Bryonia.}

Flowers monœcions or diœcious. Petals scarcely united at the base. $\sigma^{7}$ Calyx 5-toothed. Stamens 3-adelphous: anthers flexuose. \& Style 3 -fid. Fruit ovate or globose, smooth, few-seeded: seeds ovate, scarcely compressed, more or less margined.

Nume from $\beta$ guw to grow rapidly.

\section{Bryonia racemosa. Jamaica Bryony.}

Lower leaves palmato-5-lobed, the leaves higher on the stem 3-lobed and undivided, divisions oblong mucronate denticulated, flowers racemose, peduncles subsecund, fruit ovoid.

Bryonia racemosa foliis ficulneis. Plum. Amer. 83. t. 97.-B. foliis hirtis, trilobis, vel quinquelobis, racemis minoribus alaribus. Browne, 335-B, racemosa, Swartz, Fl. Ind. Occ. 1148.

HA B. Common, in thickets and by the road-sides in the mountains.

F L. December-March.

Root perennial. Stem at the base woody; afterwards herbaceous, very long, scarcely thicker than a swan's quill, anguloso-sulcated, hispid. Leaves palmate: the early leaves 5-lobed, the later ones $\mathbf{3}$, or sub-5-lobed; middle lobe the largest; lateral ones less distinct; all of them oblong, mucronato-apiculated, serrato-dentate or denticulated; nerves $\mathbf{3}$, with the lateral nerves bifurcated; veins reticulated; surface hispid; petiole subterete, channelled, hispid. Tendrils axillary, subsimple. Racemes axillary, arising between the petiole and the tendril, shorter than the petiole, about 4-flowered, subsecund. Peduncle thick, anguloso-sulcated, hispid : pedicels short, terete, 1-flowered. Flowers diœcious. $\delta$ Pedicels not more than 2 lines in length, minutely hispidulous. Calyx campanulate, contracted at the throat, 5-toothed; teeth

Vor. 2. 
small. Petals 5, linear, shortly acumirate, concave and sub-triquetrous at the apex, externally green, minutely puberulous, nearly an inch in length. Filaments triadelphous, subulate at the apex, dilated and villous at the base: anthers yellow, cohering so as to form a cylindrical body with a villous tuft in the centre. Glandules two, minute, at the base of the calyx. Rudiments of the pistil a depressed 3-lobed glandular disk. \& Calyx contracted where it parts with the ovary; afterwards dilated; contracted at the throat. Petals as in the male flowers. Abortive stamens short, white, linear, ciliated, inserted at the base of the peials. Glandules 3-5, surrounding the base of the style, globular, yellow. Style length of the corolla, compressed : stigmata 3-4, free, reflected, cordate, expanded. Fruit size of a sparrow's egg, oblong, glabrous, of a reddish-orange when ripe, 1-2-celled: cells 1-seeded : seeds oblong, slightly-compressed.

I have given a full description of this plant, as it has not hitherto been the subject of accurate examination. The appellation ficulneus employed by Plumier, is very characteristic of the leaves. Browne describes the stigma or termination of the style as divided into three thin reflected lobes, and the fruit as seldom exceeding threequarters of an inch in diameter. All parts of the plant are intensely bitter. It has received from the French the name of "Liane au mal des yeux."

\section{Momordica.}

Flowers monocious, yelluw or white: peduncles uni-bracteated, filiform. o ${ }^{\pi}$ Calyx 5-cleft, with the tube very short. Corolla 5-partite. Stamens 3-adelphous: anthers connate. \& Filaments 3, (5-triadelphous), sterile. Style 3-fid. Ovary 3celled. Fruit frequently muricated, when ripe bursting elastically. Seeds compressed, reticulatcd.

Nitime from MOMORD the perfect of MORDEO to chew, in allusion tiv the appearance of the seeds.

1. Momordica balsamina. Smooth-leaved
Cerasee.

Leaves quinquelobato-palmate coarsely toothed 
subglabrous, fruit subrotundo-ovate attennated at both ends angulato-tuberculated orange-coloured irregularly and laterally bursting, bractea above the middle of the peduncle cordate crenulated, arillus scarlet,

Cucumis puniceus, Sloane, I. 128-Momordica g!abra, Browne, 353.-M. balsamina, Linn. Spec. 1453.

II A B. On fences. Cultivated.

F L. During the greater part of the year.

Stem filiform; branches angular, glabrous. Leaves irregularly dentate, glabrous with exception of the minutely puberulous under surface of the nerves. Peduncles axillary, about an inch and a half in length, puberulous, bearing a single bractea, which is cordate, orbiculate, crenulated, puberulous, longitudinally nerved, apiculated ; placed about two or three lines below the insertion of the flower. Calycine divisions ovate, attenuato-apiculated, externally puberulous. Corolla 5-partite nearly to the base; lobes rounded, veined, puberulous. Stamens 3adelphous. Fruit nearly two inches in length, spherical, attenuated at both ends, marked with eight longitudinal rows of tubercles, bursting irregularly and laterally with an elastic spring from the base: arillus scarlet: seeds about 5, oblong, compressed, smooth.

This plant was probably introduced from the East. Ainslie informs us that the Sanscrit name of the piant is valisee, which sounds very like our cerasee. Hassclquist mentions that the fruit of this species is famous in Syria for curing wounds. The natives cut it open and infuse it in sweet oil, which they expose to the sun for a few days, and then preserve for use. Dropped on cotton and applied to a fresh wound, they consider it as a vulnerary little inferior to the Balsam of Mecca. A decoction of the root is said to act as a de-obstruent, and to promote the secretions of the liver and kidneys. An infusion of the pulp of the fruit, with the addition of the carbonate of soda, forms an elegant wash for discolorations of the cutis. The leaves are a favorite potherb in India, and have the reputation of promoting the lochial discharge when scanty. The fruit contains an insipid sweetish pulp, which Barham assures us, "purges excellently well": so that mixed with guinea-pepper it is efficacious for the cure of belly-ache. 


\section{Momordica Charantia. Hairy Cerasee.}

Leaves septemlobato-palmate dentate subhirsute, cirrhi pubescent, fruit oblong acuminate argulated tuberculated saffron-coloured or red, pulp yellow soft, bractea cordate very entire below the middle of the peduncle, seeds oblong tuberculated, arillus scarlet.

Momordica subhirsuta, Browne, 353.-M. Charantia, Linn. Spec. 1433.- Sims Bot. Mag. 2455.

HA B. On fences. Cultivated.

F L. After the May and October rains.

Stem herbaceous, pentagonal, sulcated, subhirsute, especially at the joints. Leaves subglabrous above, subhirsute beneath, especially the under surface of the nerves, ciliated and irregularly serrated: petiole $1 \frac{1}{2}-2$ inches in length: eirrhi simple, pubescent. Peduncle $2 \frac{1}{2}$ to 3 inches long, filiform, sparingly pubescent. Bractea situated below the middle of the peduncle, sessile, orbicular, apiculated, semi-amplexicaul, entire, ciliated, nerved. $\delta^{\delta}$ Calycine segments oblong, acute. Corolla three times longer than the calyx; segments longitudinally 5-veined Filaments triadelphous, short, robust: anthers cohering. i As in the male, but the peduncle elongates and becomes incrassated as the fruit ripens. Stamens none, but in their places five small glandules encircle the base of the style; one of them being single, the others in pairs Style short: stigmata 3, subcapitate, green. Ovary tuberculated, cylindrical, attenuated at both ends, 3-celled.

We are informed that the fruit of this species is much prized by the Cochin-chinese as a potherb. It supplies one of the ingredicnts of the celebrated pepper-pot of the West-Indies. It is supposed to possess similar medicinal properties as the preceding species.

\section{Sechium.}

Flowers monœcious. § Calyx subquinquedentate. Corolla closely united to the calyx. Stamens 4-5, monadelphous, free at the apex, diverging : anthers cordate, distant. \& Calyx and corolla as in the male. Stamens $O$. Style 
thick : stigma subcapitate, 3-5-cleft. Pepo obcordate, one-seeded; seed ovate, plane, compressed.

Name from onxa ${ }^{\omega} \omega$ to fatten in a stall: the fruit having the reputation of being useful for fattening hogs.

\section{Sechium edule. The Chocho.}

Stem smooth, leaves cordato-angulated, lobes connivent at the base dentate, terminal lobe the longest acuminate, tendrils 4-5-cleft, male flowers racemose, female solitary in the same axilla, fruit obovate 5 -sulcated gibbous at the apex piloso-echinated.

Sechium foliis cordato-angulatis, racemis minoribus ad alas, Browne, 355.-Sicyos edulis, Swartz, Prod. 116.-Sechium edule, Swartz, Fl. Ind. Occ. 1150.

II A B. Cultivated. In thickets.

F L. Throughout the year.

The root of the mature plant is large and fleshy, resembling the yam in appearance, and weighing from 10 to 20 pounds. The male flowers are arranged in a raceme, which is axillary and longer than the petiole. Female flowers subsolitary, axillary, shortly peduncled, accompanying the male raceme. Fruit large, carnoso-succulent, about 4 inches in length, usually furnished with small herbaceous prickles. Seed ovate, compressed, an inch in length, greenish, divisible into two plates, protruding from the cleft apex of the fruit when ripe.

This is a very wholesome fruit, being one of the few vegetable productions of our gardens which admit of being made use of even by the most delicate stomachs. Like the Ochra, and the Indian-Kale, I never knew either spasm or flatulence, or any of the usual symptoms, of indigestion occasioned by it. There are two varieties of the Chocho in cultivation; 1st, the common green; and 2nd, the white. The latter is by far the most delicate. With the addition of lime juice and sugar, it supplies an ingredient for tarts. The root when dressed is very wholesome and palatable, and can scarcely be distinguished from the yam. 
This is the Clucho of South America, and the Chayote of Cuba.

\section{L L ANDERSIA.}

Flowers monocious. Calyx 5-toothed. Corolla 5-cleft: divisions bilobed. $\approx$ Stamens 3, distinct : anthers lineari-oblong, tetragonal, truncated, with the cells lateral and linear. \& Style 3-cleft, surrounded at the base with an urceolated disk : stigma capitate, bipartite : divisions oblong, acute. Fruit ovoid, 3-celled, many-seeded.

Name bestowed in memory of Landers, the African Traveller.

\section{Landersia pervaga. Straggling Landersia.}

Cucumis minima, fructu ovali nigro lævi. Sloane, 1. 227. t. 142. f 1.-Melothria scandens, Brownc, 124.Melothria pendula. Linn. Sp. 49.

II A B. Common on fences, and in ruinate Coffee-pieces.

F L. Throughout the year.

Root composed of filiform white branching fibres. Stem herbaceous, filiform, anguloso-sulcated, subglabrous, scandent, sarmentose at the base. Leaves alternate, petiolate, sub-triangulari-cordate, usually sub-trilobate; the middlc lobe the largest, terminating in a callous apicula; lateral lobes usually augmented by a smaller lobe, thus rendering the leaf sub-quinque-lobate: all of them angulari-dentate, hispid, nerved, and veined, shining, of a deep g!cen colour: petiole subterete, angular, channelled, hispidulous. Tendrils solitary, simple. Flowers small, yellow. $\delta$ Racemes arising between the petiole and the tendril, solitary, few-flowered, shorter than the petiole: pedicels half an inch in length, filiform, 1-flowered. Calyx campanulate, ventricose, contracted at the throat: teeth 5, minute, sharp, erect. Petals 5, united to form a monopetalous corolla, internally, especially at the throat, minutely puberulous: limb 5-cleft; divisions bi-lobed, with the lobes rounded. Stamens 3, scarcely longer than the tube of the corolla: anthers linear, 4-seeded : cells 2 , linear, lateral, with the margins aurantio-ciliulated. $\mathbf{R u}$ diments of the pistil a depressed annular disk. \& Flow- 
ers on a solitary filiform reverted axillary pedicel twice the length of the petiole, accompanying the male raceme. Calyx and corolla as in the barren flower. Vestiges of the stamens obscure. Disk urceolate, crenulated. Ovary oblong: style short: stigma capitate, 3-partite, with the divisions bifid. Berry pendulous, size of a sparrow's egg, ovoid, purple when ripe, glabrous, 3-celled: sceds numerous, ovate, albido-sericeo-villous, inserted by the sharp end to the angle formed by the septum and the rind.

This is a very common plant in the mountains, and in seasonable districts. When it grows in a cleared place, it may be observed sending out a long filiform sarmentum in search of some shrub or other object to which it may attach itself. As I could not reconcile this plant, to the generic characters of MELOTHRIA, I preferred forming a new genus for its reception.

\section{Trichosanthes.}

Flowers monœcious, white. $\approx$ Calyx subclavate, 5-partite; lobes setaceo-apendiculated, externally furnished with 5 teeth alternating with the lobes. Corolla 5-partite, ciliated. Filaments with 3 stamens (triadelphous): anthers coalescing, with the locules very flexuose. \& Calyx 5-toothed. Corolla 5-partite, lacinioso-ciliated. Style 3-fid: stigmata oblong, subulate. Fruit oblong, 1 ?-3-9-celled. Seeds compressed, tunicated, obtuse, much depressed.-DC.

Name from rg口ss hairs, and avtos a flower in allusion to the lobes of the corolla being fringed or ciliated.

\section{Trichosanthes Colubrina. Snake-plant.}

Stem sulcated, cirrhi tripartite, leaves cordatosubrotund obsoletely 3-5.lobed remotely toothed villoso-pubescent, male flowers panicled, female flowers axillary subsessile arising with the peduncle of the male flowers. Calyx very long with the limb reflected, fruit subterete very long, sceds oboyate red. 
H A B. Cultivated.

F L. After the rains.

This vine furnishes in its fruit a very remarkable vegetable production. It is about four feet long and an inch in diameter, and has a great resemblance in form and appearance to the yellow snake of the country. I am not aware that it is adapted for any purpose.

\section{Trichosanthes pomiformis. Globular. fruited Trichosanthes.}

Stem terete striated subglabrous, cirrhi simple, leaves ovate cordate acute sub-tri-lobate denticulated, glabrous above, hispid especially along the nerves beneath, $\delta$ fl. with the peduncle longer than the petiole, of $f$. with the peduncle onethird the length of the former, calyx campanulate with the lobes lanceolate and spreading, petals ciliated, fruit 3-celled, with each cell about 9seeded.

Trichosanthes foliis denticulatis quandoque trilobis, quandoque cordatis, fructu subrotundo. Browne, 354.T. amara? Linn. Sp. 1432.

H A B. The higher mountains.

F L. January-May.

Stem climbing to a great height, with the branches sus. pended from trees, especially along the road-sides in the mountains. Leaves with the lobes subacuminate and apiculated, 3-nerved with lateral nerves bifid: petiole compressed. $\delta$ Flowers with the peduncle axillary, subsolitary, one-flowered, an inch and a half in length. Flowers large, greenish-white. Calyx subpentagonal, campanulate, hispid; limb with 5 leaf-like lanceolate spreading lobes alternating with 5 small teeth. Corolla tomentose and ciliated, with the lobes oval, obtuse, longitudinally nerved. Stamens 5, triadelphous : filaments woolly : anthers large, cohering, very flexuose Rudiments of the pistil none. \& Flowers with the peduncle accompanying that of the male flower, half an inch in length, thick, terete, hispidulous, one-flowered. Calyx and corolla as above. Filaments 3 , subulate, length of the styles, woolly with transparent hairs : anthers awanting. Ovary globu- 



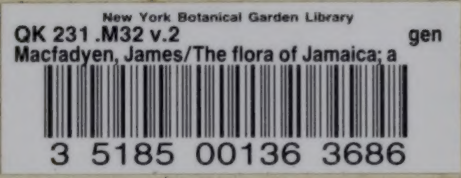


